\title{
From Sea to Shining Sea and the Great Plains to Patagonia: A Review on Current Knowledge of Diabetes Mellitus in Hispanics/Latinos in the US and Latin America
}

\begin{abstract}
M. Larissa Avilés-Santa ${ }^{1 *}$, Uriyoán Colón-Ramos², Nangel M. Lindberg ${ }^{3}$, Josiemer Mattei ${ }^{4}$, Francisco J. Pasquel ${ }^{5}$ and Cynthia M. Pérez ${ }^{6}$

${ }^{1}$ National Heart, Lung, and Blood Institute at the National Institutes of Health, Bethesda, MD, United States, ${ }^{2}$ Department of Global Health, Milken Institute School of Public Health, George Washington University, Washington, DC, United States, ${ }^{3}$ Kaiser Permanente Center for Health Research, Portland, OR, United States, ${ }^{4}$ Department of Nutrition, Harvard TH Chan School of Public Health, Boston, MA, United States, ${ }^{5}$ Department of Medicine, Emory University School of Medicine, Atlanta, GA, United States, ${ }^{6}$ University of Puerto Rico Graduate School of Public Health, San Juan, Puerto Rico
\end{abstract}

OPEN ACCESS

Edited by:

MariaRosario (Happy) Araneta, University of California, San Diego,

United States

Reviewed by:

Jan Brož,

Charles University, Czechia

Cecilia B. Rosales,

University of Arizona

United States

*Correspondence:

M. Larissa Avilés-Santa

avilessantal@nhlbi.nih.gov

Specialty section: This article was submitted to Diabetes,

a section of the journal Frontiers in Endocrinology

Received: 19 May 2017 Accepted: 16 October 2017 Published: 10 November 2017

Citation: Avilés-Santa ML, Colón-Ramos U, Lindberg NM, Mattei J, Pasquel FJ and Pérez CM (2017) From Sea to Shining Sea and the Great Plains to Patagonia: A Review on Current Knowledge of Diabetes Mellitus in Hispanics/Latinos in the US and Latin America.

Front. Endocrinol. 8:298. doi: 10.3389/fendo.2017.00298
The past two decades have witnessed many advances in the prevention, treatment, and control of diabetes mellitus (DM) and its complications. Increased screening has led to a greater recognition of type 2 diabetes mellitus (type 2 DM) and prediabetes; however, Hispanics/Latinos, the largest minority group in the US, have not fully benefited from these advances. The Hispanic/Latino population is highly diverse in ancestries, birth places, cultures, languages, and socioeconomic backgrounds, and it populates most of the Western Hemisphere. In the US, the prevalence of DM varies among Hispanic/Latino heritage groups, being higher among Mexicans, Puerto Ricans, and Dominicans, and lower among South Americans. The risk and prevalence of diabetes among Hispanics/ Latinos are significantly higher than in non-Hispanic Whites, and nearly $40 \%$ of Hispanics/ Latinos with diabetes have not been formally diagnosed. Despite these striking facts, the representation of Hispanics/Latinos in pharmacological and non-pharmacological clinical trials has been suboptimal, while the prevalence of diabetes in these populations continues to rise. This review will focus on the epidemiology, etiology and prevention of type $2 \mathrm{DM}$ in populations of Latin American origin. We will set the stage by defining the terms Hispanic, Latino, and Latin American, explaining the challenges identifying Hispanics/Latinos in the scientific literature and databases, describing the epidemiology of diabetes -including type 2 DM and gestational diabetes mellitus (GDM) - and cardiovascular risk factors in Hispanics/Latinos in the US and Latin America, and discussing trends, and commonalities and differences across studies and populations, including methodology to ascertain diabetes. We will discuss studies on mechanisms of disease, and research on prevention of type 2 DM in Hispanics/Latinos, including women with GDM, youth and adults; and finalize with a discussion on lessons learned and opportunities to enhance research, and, consequently, clinical care oriented toward preventing type 2 DM in Hispanics/Latinos in the US and Latin America.

Keywords: type 2 diabetes mellitus, gestational diabetes, prevention of diabetes, Latinos, Latin America, epidemiology of type 2 diabetes, Hispanics 


\section{INTRODUCTION}

Poverty is the best cure for diabetes.

La pobreza es el mejor remedio contra la diabetes. -Gabriel García Márquez (1)

Diabetes mellitus (DM) has been documented in the medical history of some Latin American countries since the late 1800s and early 1900s $(2,3)$. Although not a common disease at that time, type $1 \mathrm{DM}$ was highlighted by medical societies in the Americas due to its dramatic presentation and fast clinical deterioration. In contrast, type 2 diabetes mellitus (type $2 \mathrm{DM}$ ) and its longterm complications only gained attention in the mid-twentieth century $(2,3)$. Over the next decades, type $2 \mathrm{DM}$ would become recognized not just as a common chronic disease but also as one of the leading causes of death worldwide (4).

\section{Why Is It Important to Understand Type 2 Diabetes in Hispanics/Latinos in the US and in Latin Americans?}

Hispanics/Latinos in the US mainland constitute $17.6 \%$ of the population (5), and are the largest US minority group. It is projected that by year 2060, 29\% of the US population will be of Hispanic/Latino descent (6). Compared to other US populations, the Hispanic/Latino population is younger, with nearly half of the US-born Hispanics/Latinos under age 18 (7). The prevalence of diabetes among Hispanics/Latinos in the US is $22.6 \%$, and twice as high as that of non-Hispanic Whites (NHWs) (11.3\%) (8). Diabetes has also become a leading cause of death in Latin America $(9,10)$.

Understanding type $2 \mathrm{DM}$ among Hispanics/Latinos in the US and in Latin America poses several challenges. A long-standing assumption in the US is that Hispanics/Latinos are a demographically and ancestrally homogeneous group. However, as we will explain, Hispanics/Latinos are a highly heterogeneous group, and in fact, the prevalence of diabetes varies widely among different US Hispanic/Latino heritage groups (11-13). These differences in prevalence may be mediated by differences in ancestry, as well as differences in socioeconomic factors, cultural norms, dietary and physical activity (PA) patterns, and history of environmental exposures-among others-experienced in both the country of origin and the US.

As the foundations for precision and personalized medicine are built, it is clear that adequate prevention, diagnosis, and treatment of type $2 \mathrm{DM}$ among Hispanics/Latinos in the US and in Latin America require deep understanding of its etiology, manifestations, and response to interventions across populations. Whereas diabetes has become a seemingly unavoidable outcome for many Hispanics/Latinos, it does not have to be so.

In this expert review, we will describe the epidemiology of type $2 \mathrm{DM}$ and gestational diabetes mellitus (GDM) and traditional cardiovascular (CV) risk factors in Hispanics/Latinos in the US and Latin America based on selected studies. We will also discuss studies on the etiology of type 2 DM and GDM in Hispanic/Latino populations. Given the increasing prevalence of type $2 \mathrm{DM}$ across the continent, and especially at younger ages, we considered imperative to focus on research dedicated to disease prevention in Hispanics/Latinos in the US and in Latin America. We will also highlight opportunities to enhance our knowledge through research within a holistic framework of multidimensional and transdisciplinary strategies; a framework that is also applicable to the clinical care of Hispanics/Latinos at risk of type 2 DM.

In this review, the term type $2 \mathrm{DM}$ will be used throughout most of the text, and specially within the context of etiology and prevention. The term diabetes will be used within the context of epidemiology or when there is no distinction between type 1 and type 2 DM. As a reference, we have also included a list of acronyms and abbreviations used throughout the text (see Appendix).

\section{Who Are the Hispanics/Latinos in the US and Latin Americans?}

The Office of Management and Budget (OMB) and the US Census Bureau define Hispanic or Latino as "a person of Cuban, Mexican, Puerto Rican, South or Central American, or other Spanish culture regardless of race" (14). The racial and ethnic categories defined by the OMB have been challenged and are under revision (15). Figure 1 (16) illustrates where the largest Hispanic/Latino heritage groups live in the US and Puerto Rico based on the 2010 US Census.

The terms Hispanic and Latino have different meanings in the US and abroad. Place of residence (17), ancestry group (18), or immigrant generation (18) may influence individuals' preference for the term Hispanic, Latino, both, or neither. In this review, the term Hispanic/Latino refers to persons of Latin American descent who live in the US or in Latin America; that is, those who self-identify or trace their roots to countries in the Americas where Spanish, Portuguese, and French are the predominant languages $(19,20)$, excluding persons from Spain. The term Latin Americans refers to persons or populations in Latin America $(19,20)$.

\section{Sociodemographic and Economic Characteristics of the Hispanic/Latino Population in the US and in Latin America}

According to the US Census Bureau, Hispanics/Latinos have become the US largest minority group. This population increased nearly fourfold between 1980 and 2015, rising from 14.8 million (6.5\%) to 56.6 million (17.6\%) (21-23). The Hispanic/Latino population is projected to increase to 119 million, or nearly $29 \%$ of the population in 2060 (6), with growth attributed to high rates of immigration and fertility, and low overall mortality (24). In 2015, Hispanics/Latinos of Mexican origin were the largest Hispanic/ Latino heritage group (63\%), followed by Puerto Ricans (10\%), Salvadorans (4\%), Cubans (4\%), and Dominicans (3\%) (21).

As a group, Hispanics/Latinos are younger than other racial/ ethnic groups in the US (median 28.7 years) and lag behind other groups in educational attainment (21) (Table 1). At 67\%, the percentage of Hispanics/Latinos age 25 or older with a high school education or higher is significantly lower than that of NHWs (91.8\%) (25). Poverty rates are significantly higher among Hispanics/Latinos (21.4\%) than NHWs (9.1\%) (26). In the US, unemployment among the population aged 16 years and older 


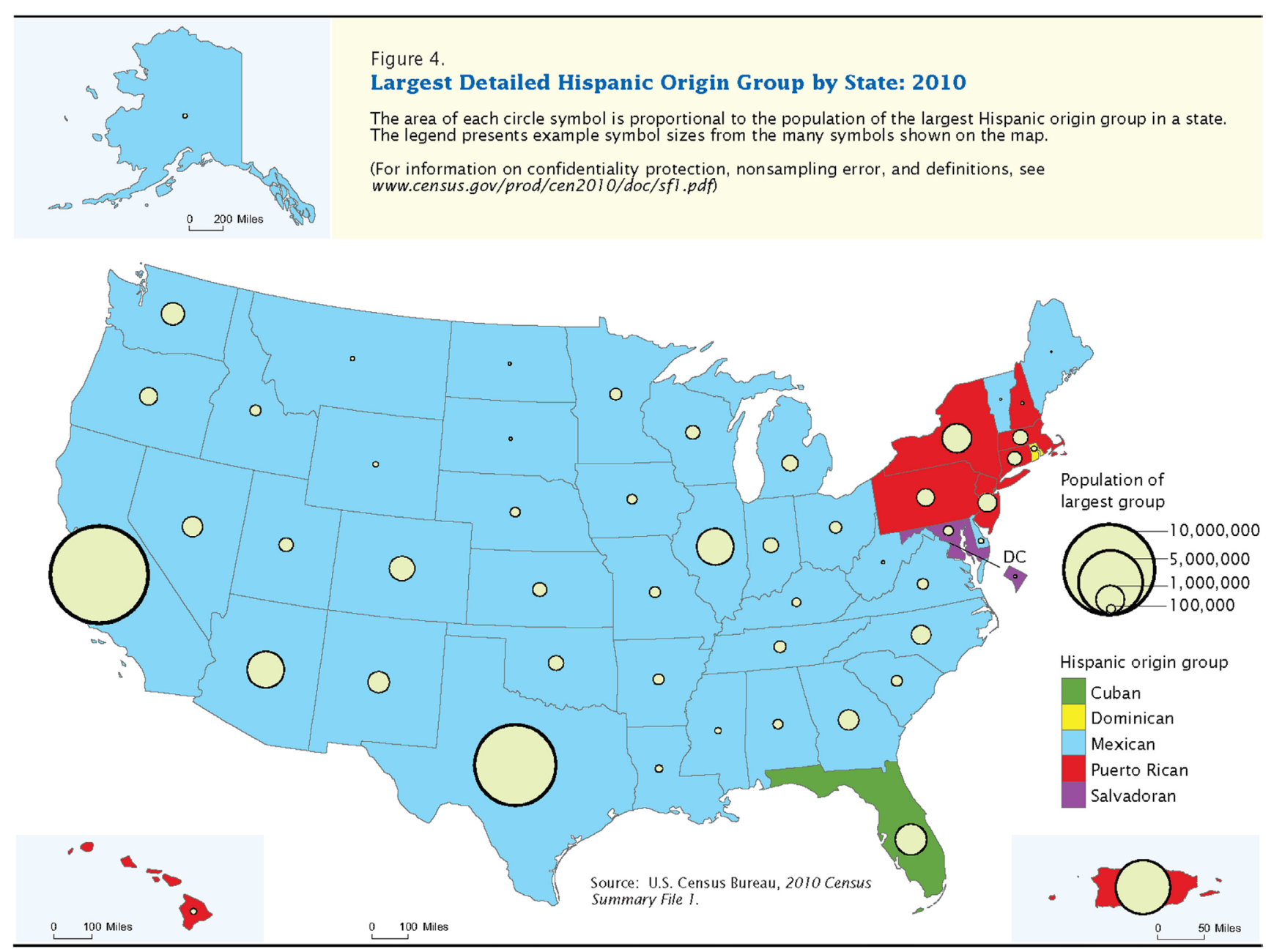

FIGURE 1 | 2010 US Census Map_Largest Detailed Hispanic Origin Group by State: 2010. This is Figure 4 from Ennis et al. (16).

TABLE 1 | Selected socioeconomic indicators for Hispanics/Latinos in the US by heritage group, 2015. ${ }^{\text {a }}$

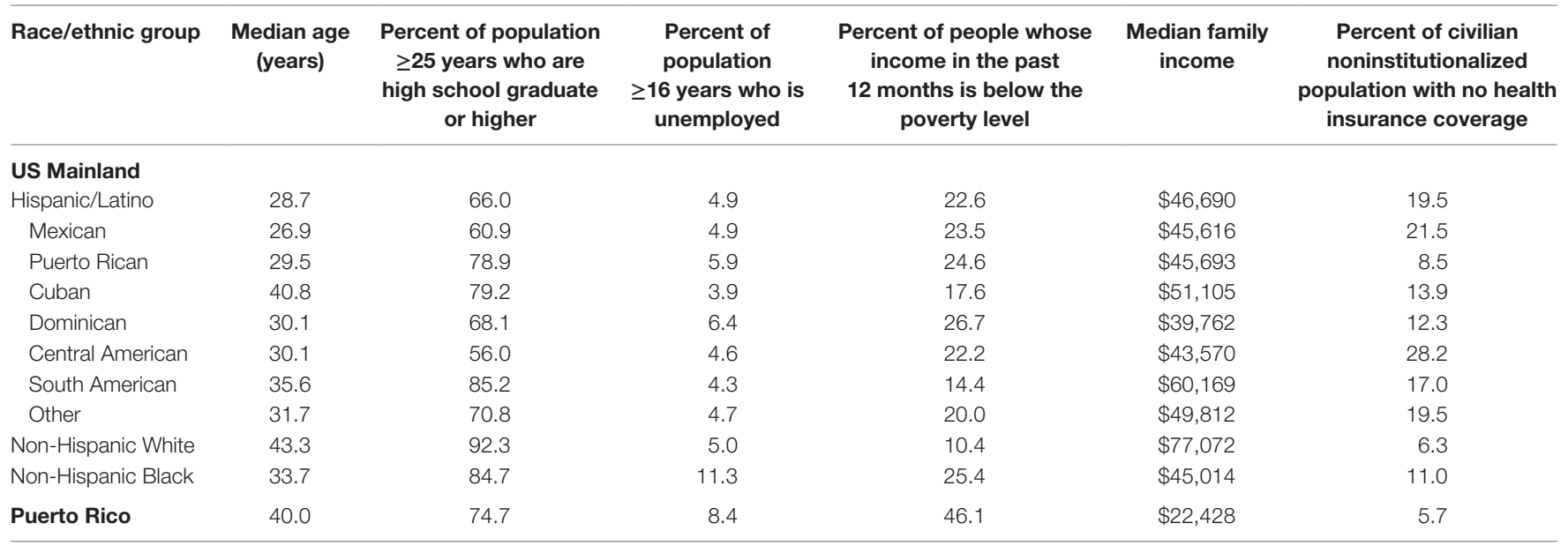

aSource: US Census Bureau, 2015 American Community Survey 1-Year Estimates. 
was highest among non-Hispanic Blacks (11.3\%) and islander Puerto Ricans (8.4\%), and lowest among NHWs (5\%) and Hispanics/Latinos (4.9\%). Islander Puerto Ricans continue to have higher poverty rates $(46.1 \%)$ than other Hispanics/Latino groups in the US (22.6\%), non-Hispanic Blacks (25.4\%), and NHWs (10.4\%) (21).

Hispanics/Latinos of any race are disproportionately affected by lack of health insurance compared to all other groups (27). While only approximately $10 \%$ of NHWs did not have healthcare insurance, nearly $20 \%$ of Hispanics/Latinos of any race lack health insurance. Within Hispanic/Latino subgroups, the percentage of uninsured individuals varied considerably, from $8.5 \%$ in Puerto Ricans to $28.2 \%$ in Central Americans $(28,29)$.

The population in Latin America and the Caribbean is projected to grow from 646 million currently to 784 million in 2050 (30). This population is relatively young with a median age of 29.2 years (31) (Table 2). Enrollment in secondary and tertiary education remains unequal in the region, ranging from $21.2 \%$ in Honduras to $88.6 \%$ in Chile. The percentage of the population classified as poor is highly variable, from $4.3 \%$ in Argentina to over $60 \%$ in Guatemala and Honduras.

\section{Challenges in Identifying Hispanics/ Latinos in US Government Reports and the Scientific Literature \\ Demographic Terminology}

From the late 1800s and through most of the twentieth century, several terms have been used in the Census data and the medical literature to attempt to identify persons of Mexican origin, and later other Hispanics/Latinos (32, 33). Not surprisingly, the terms failed to accurately identify this elusive and complex mosaic of populations.

Through several modifications to the US Census since 1970 (33), blanket demographic terms such as "Hispanic" and "Latino" have been used to attempt to capture the specific cultural identities within the "Hispanic or Latino" populations. Despite the population's diversity in virtually every element, this conglomerate of races, nationalities, and cultures is still regarded by many as a monolith.

\section{Publications on US Hispanic/Latino Health}

The earliest scientific reports on the health of any US Hispanic/ Latino heritage group date from 1929 or earlier (34), and focused on tuberculosis in Mexican immigrants. Subsequent studies published from the 1950s to the 1970s addressed farm laborers' health (35), folk medicine (36), sociological, psychiatric, and behavioral issues (37-42), hematologic and gastrointestinal disorders (43-46), infectious and tropical diseases (47-49), and women's fertility (50), among other topics, and focused on Mexican immigrants, Puerto Rican migrants, and Puerto Rico. Thus, for most of the twentieth century, health-related studies in Hispanics/Latinos were isolated and did not address chronic diseases; furthermore, the manner in which Hispanics/Latinos were classified was inconsistent. Although the Framingham Heart Study was initiated in 1948 (51), and its first analyses on the incidence of cardiovascular disease (CVD) and associated risk factors were published between 1957 and 1959 (52, 53), the study of chronic diseases, in particular CV morbidity and mortality, in Hispanics/Latinos in the US did not start until the 1960s (54).

As we will describe, differences and similarities in the prevalence of diabetes and CV risk factors between Hispanics/Latinos

TABLE 2 | Selected socioeconomic indicators for Hispanics/Latinos in Latin America, 2014-2015.

\begin{tabular}{|c|c|c|c|c|}
\hline Country & $\begin{array}{c}\text { Median age } \\
\text { (years), 2015 }\end{array}$ & $\begin{array}{c}\text { Gross enrollment rate in secondary and } \\
\text { tertiary education, } 2014^{\mathrm{b}}\end{array}$ & $\begin{array}{l}\text { Economic participation rate in } \\
\text { population aged } \geq 15,2015^{b}\end{array}$ & $\begin{array}{l}\text { Percentage of population } \\
\text { classified as poor, } 2014^{b}\end{array}$ \\
\hline Argentina & 30.8 & 88.2/NA & 59.6 & 4.3 \\
\hline Bolivia & 24.1 & 75.7/NA & 69.6 & 32.7 \\
\hline Brazil & 31.3 & NA & 66.6 & 16.5 \\
\hline Chile & 34.4 & 88.3/88.6 & 57.4 & 7.8 \\
\hline Colombia & 30.0 & $78.6 / 51.3$ & 69.4 & 28.6 \\
\hline Costa Rica & 31.4 & $78.1 / 53.0$ & 59.6 & 18.6 \\
\hline Cuba & 41.2 & NA/41.0 & NA & NA \\
\hline Dominican Republic & 26.1 & $65.5 / 47.5$ & 58.8 & 37.2 \\
\hline Ecuador & 26.6 & NA & 64.4 & 29.8 \\
\hline El Salvador & 26.7 & $70.2 / 28.9$ & 61.6 & 41.6 \\
\hline Guatemala & 21.2 & 46.7/NA & 62.2 & 67.7 \\
\hline Honduras & 23.4 & $49.3 / 21.2$ & 61.6 & 74.3 \\
\hline México & 27.4 & NA/29.9 & 63.2 & 41.2 \\
\hline Nicaragua & 25.2 & NA & 62.4 & 58.3 \\
\hline Panama & 28.7 & NA & 64.0 & 21.4 \\
\hline Paraguay & 24.9 & NA & 68.6 & 42.3 \\
\hline Perú & 27.5 & 78.4/NA & 71.8 & 22.7 \\
\hline Uruguay & 34.9 & NA & 65.8 & 4.4 \\
\hline Venezuela & 27.4 & 74.8/NA & 64.8 & 32.1 \\
\hline
\end{tabular}

aSource: United Nations, Department of Economic and Social Affairs, Population Division (2015). World Population Prospects: The 2015 Revision, Key Findings and Advance Tables. Working Paper No. ESA/P/WP.241.

'SSource: Economic Commission for Latin America and the Caribbean (ECLAC), Statistical Yearbook for Latin America and the Caribbean, 2016 (LC/PUB.2017/2-P), Santiago, 2016. Data correspond to the most recent available year. 
and other racial/ethnic groups, and among Hispanic/Latino heritage groups would gradually be documented by various studies across the US. Understanding these differences and similarities could shed light on the interaction among various health determinants, and diabetes risk across populations. These differences and similarities are still being investigated.

\section{EPIDEMIOLOGY OF DM IN HISPANICS/ LATINOS IN THE US AND LATIN AMERICA}

\section{Diabetes in Hispanics/Latinos in the US}

During the past three decades of the twentieth century, reports about chronic diseases-including diabetes-in the US Hispanic/Latino population started to be generated and disseminated through several epidemiological studies, including but not limited to the Puerto Rico Heart Health Program (54, 55), the Laredo Project (56), the San Antonio Heart Study (SAHS) $(57,58)$, the Hispanic Health and Nutrition Examination Survey (Hispanic HANES) $(11,59,60)$, the San Luis Valley Diabetes Study (61), and later the National Health Interview Survey (NHIS) (28), the Behavioral Risk Factor Surveillance Survey (BRFSS) (62), and the National Health and Nutrition Examination Survey (NHANES) (63). However, most of the studies were cross-sectional and focused on one Hispanic/Latino heritage group or specific region of the US. Of these, the Hispanic HANES, conducted from 1982 to 1984, was the first epidemiological study to describe the prevalence of some chronic diseases, including diabetes, in the three largest Hispanic/Latino heritage groups at the time: Mexicans, Puerto Ricans, and Cubans $(11,59,60)$. However, the Hispanic HANES was a one-time cross-sectional study. In 2006, the Hispanic Community Health Study/Study of Latinos (HCHS/SOL), a prospective study, was established to describe the prevalence of chronic diseases (especially CV and pulmonary), identify their risk or protective factors, and correlate them with future health outcomes in a cohort of US Hispanics/Latinos from diverse origins in a cohort of over 16,000 Hispanic/Latino adults from Central American, Cuban, Dominican, Mexican, Puerto Rican, and South American heritage living in San Diego, Chicago, Miami, and New York $(64,65)$.

There are important differences in these studies that make comparisons across them difficult: methodological variations in selection of study populations, diagnostic criteria to determine diabetes, lack of assessment to distinguish between type 1 and type 2 DM, proposed diagnostic cut points (66-68), and time-period of analysis. Further caution must be taken when interpreting data gathered across studies, because the lack of confirmatory testing of diagnostic criteria in some studies could result in an inaccurate estimate of the prevalence (66). Since some surveys restrict their sampling to specific geographic areas, generalizability of the findings to all Hispanics/Latinos living in the US or Latin America is reduced.

Table 3 lists selected US epidemiological studies focused on or that have included Hispanics/Latinos, and that have estimated diabetes prevalence $(8,11-13,54-61,64,65,69-95)$. An analysis of the 2011-2012 NHANES cycle showed that the unadjusted prevalence of total diabetes based on ADA criteria (2-h OGTT, FPG, or HbA1c) was $14.3 \%$ (9.1\% for diagnosed diabetes and $5.2 \%$ for undiagnosed diabetes) and $38.0 \%$ for prediabetes (8). The prevalence of total diabetes for those of Hispanic/Latino heritage was twice as high (22.6\%) than for NHWs (11.3\%) and higher than the other racial/ethnic groups included in the study. The age-standardized prevalence of undiagnosed diabetes among Hispanic/Latino adults (49.0\%) was significantly higher than that for NHWs (32.3\%), and slightly lower than that for non-Hispanic Asians (50.9\%) (8).

The baseline examination of the HCHS/SOL (2008-2011) showed that the prevalence of diabetes ranged from $10.2 \%$ in South Americans to $18.1 \%$ in Dominicans and Puerto Ricans and $18.3 \%$ in Mexicans (12). Prevalence by sex ranged from a low of $10.6 \%$ for South American men to a high of $18.7 \%$ for Mexican men, and from $9.8 \%$ in South American women to $19.5 \%$ in Puerto Rican women. Diabetes prevalence increased significantly with age and BMI but was inversely associated with years of education and household income (12). Although the prevalence of diabetes also increased significantly with length of residence in the US, it was similar among US-born participants and foreign-born participants residing in the US for fewer than 5 years. However, the prevalence was significantly higher among foreign-born participants with longer than 10 years of residence in the US. Nearly half of Hispanics/Latinos (48\%) had adequate glycemic control, a rate slightly lower than those for NHWs (52.9\%) and non-Hispanic Blacks (52.6\%) who participated in the 1988-2010 NHANES cycles (96). Preliminary data from the second examination of the HCHS/SOL (2014-2017) demonstrated an overall increase in prevalence of diabetes, which is still higher among Mexicans, Dominicans, and Puerto Ricans and lower among Cubans (97).

The HCHS/SOL also determined that nearly $40 \%$ of Hispanics/ Latinos with diabetes met at least one ADA criterion of undiagnosed diabetes (13). This finding is consistent with a recent NHANES data analysis that showed that Mexican Americans and other Hispanic women were more likely to be unaware of their diabetes status (98).

An additional analysis of HCHS/SOL baseline data found that $36.3 \%$ of the target population met at least one of the ADA criteria for prediabetes (97). Prevalence of prediabetes varied by age, sex, Hispanic/Latino heritage groups, and BMI categories, but was similar across place of birth and years living in the US. In the 2011-2012 NHANES cycle, the overall prevalence of prediabetes was $38.0 \%$, and $36.8 \%$ for all Hispanics/Latinos (8).

Although there is a paucity of studies examining the prevalence of type $2 \mathrm{DM}$ among children and adolescents, evidence suggests that prediabetes is highly prevalent among Hispanic/ Latino adolescents in the US. In a recent analysis based on the 2005-2014 NHANES cycles, the prevalence of prediabetes (based on FPG, 2hPG, or HbA1c) among all Hispanic/Latino adolescents (aged 12-19 years) was 22.9\%. Among Mexican Americans it was $22.4 \%$, significantly higher $(P=0.001)$ than in NHWs (15.1\%) (94). Recent data from the Study of Latino Youth, a population-based cross-sectional study of 1,466 Hispanic/ Latino youth aged 8-16 years, found a combined prevalence of prediabetes and diabetes (based on FPG and HbA1c) of $16.5 \%$ 
TABLE 3 | Prevalence of type 2 diabetes and prediabetes among Hispanic/Latino populations in the US (selected studies).

\begin{tabular}{|c|c|c|c|c|c|}
\hline $\begin{array}{l}\text { Study } \\
\text { (reference) }\end{array}$ & $\begin{array}{l}\text { Study } \\
\text { period }\end{array}$ & Sample size & $\begin{array}{l}\text { Age range } \\
\text { (years) }\end{array}$ & Glycemic criteria & Key findings \\
\hline $\begin{array}{l}\text { Puerto Rico } \\
\text { Heart Health } \\
\text { Program }(54,55)\end{array}$ & $1965-1980$ & $\begin{array}{l}2,567 \text { rural and } 6,190 \text { urban } \\
\text { Puerto Rican men }\end{array}$ & $45-64$ & $\begin{array}{l}\mathrm{FPG} \geq 126 \mathrm{mg} / \mathrm{dL} \\
\text { self-reports of physician- } \\
\text { diagnosed diabetes, } \\
\text { or use of insulin or } \\
\text { hypoglycemic agents }\end{array}$ & $3.6 \%$ in rural men and $9 \%$ in urban men \\
\hline $\begin{array}{l}\text { Laredo } \\
\text { Project (56) }\end{array}$ & 1979 & 389 Mexican Americans & $40-74$ & $\begin{array}{l}\text { Fasting hyperglycemia } \\
\text { defined as } \\
\text { FPG }>140 \mathrm{mg} / \mathrm{dL}\end{array}$ & $\begin{array}{l}\text { Age-adjusted prevalence was } 10.9 \% \text { in men and } 10.1 \% \\
\text { in women }\end{array}$ \\
\hline $\begin{array}{l}\text { Starr County } \\
\text { Study, Texas (69) }\end{array}$ & 1981 & 2,498 Mexican Americans & $\geq 15$ & $\begin{array}{l}\text { Zero-hour (fasting) plasma } \\
\text { glucose level } \geq 140 \mathrm{mg} / \mathrm{dL} \\
\text { or a } 2 \text {-h level } \geq 200 \mathrm{mg} / \mathrm{dL}\end{array}$ & $6.9 \%$ males and $6.7 \%$ females \\
\hline $\begin{array}{l}\text { Albuquerque, } \\
\text { New Mexico (70) }\end{array}$ & 1984-1985 & 1,175 Hispanics & $\geq 18$ & Self-reported diagnosis & $\begin{array}{l}\text { Prevalence increased with age: men: } 1.9 \% \text { in } \\
25-34 \text { to } 13.8 \% \text { in } \geq 75 \text {. } \\
\text { Women: } 0.6 \% \text { in } 25-34 \text { to } 16.1 \% \text { in } \geq 75\end{array}$ \\
\hline $\begin{array}{l}\text { San Luis Valley } \\
\text { Diabetes Study, } \\
\text { Colorado }(61,71)\end{array}$ & 1984 & $\begin{array}{l}607 \text { Hispanics without prior } \\
\text { history of DM } \\
343 \text { Hispanics with } \\
\text { previously diagnosed DM }\end{array}$ & $20-74$ & $\begin{array}{l}\text { History of previously } \\
\text { diagnosed DM with } \\
\text { confirmation using } \\
\text { FPG } \geq 140 \mathrm{mg} / \mathrm{dL} \text { or } 2-\mathrm{h} \\
\text { OGTT } \geq 200 \mathrm{mg} / \mathrm{dL}\end{array}$ & $\begin{array}{l}\text { Age-adjusted prevalence of previously diagnosed DM: } \\
3.3 \% \text { in men and } 4.9 \% \text { in women } \\
\text { Newly diagnosed DM: } 2.2 \% \text { in men and } 4.3 \% \text { in women }\end{array}$ \\
\hline $\begin{array}{l}\text { San Antonio Heart } \\
\text { Study, Texas }(57, \\
58,72)\end{array}$ & $\begin{array}{l}\text { First phase: } \\
\text { 1979-1982 } \\
\text { Second } \\
\text { phase: } \\
\text { 1984-1988 }\end{array}$ & 3,302 Mexican Americans & $25-64$ & 2-h OGTT & $\begin{array}{l}\text { Age-adjusted prevalence for men was } 14.0 \% \text { in the } \\
\text { barrio vs. } 6.5 \% \text { in the suburbs and for men was } 18.0 \% \\
\text { in the barrio vs. } 4.3 \% \text { in the suburbs. } \\
\text { Prevalence was two to three times higher in Mexican } \\
\text { Americans than in NHWs. }\end{array}$ \\
\hline $\begin{array}{l}\text { Puerto Rico } \\
\text { Household } \\
\text { Health Interview } \\
\text { Survey (73) }\end{array}$ & 1975-1986 & $\begin{array}{l}\text { Minimum sample size } \\
\text { of } 2,696 \text { in } 1983 \\
\text { Maximum sample size of } \\
12,212 \text { in } 1976\end{array}$ & All ages & Self-reported diagnosis & $\begin{array}{l}3.1 \% \text { in } 1975 \text { to } 5.1 \% \text { in } 1986 \\
4.5 \% \text { of males and } 5.8 \% \text { of females reported a history } \\
\text { of DM }\end{array}$ \\
\hline HHANES (11) & $1982-1984$ & 6,588 Hispanics & $20-74$ years & $\begin{array}{l}\text { OGTT administered to } \\
\text { subsample of } 1,326\end{array}$ & $\begin{array}{l}\text { Cubans 45-74: } 15.8 \% \\
\text { Mexican Americans 45-74: 23.9\% } \\
\text { Puerto Ricans 45-74: } 26.1 \% \\
\text { Cubans 20-44: 2.4\% } \\
\text { Mexican Americans 20-44: 3.8\% } \\
\text { Puerto Ricans 20-44: 4.1\% }\end{array}$ \\
\hline $\begin{array}{l}\text { Mexico City } \\
\text { Diabetes } \\
\text { Study }(74)\end{array}$ & $1979-1982$ & $\begin{array}{l}\text { 2,282 individuals of Mexican } \\
\text { descent in San Antonio, and } \\
\text { Mexicans in Mexico City }\end{array}$ & $35-64$ & $\mathrm{FPG} \geq 126 \mathrm{mg} / \mathrm{dL}$ & $\begin{array}{l}\text { San Antonio: } 17.8 \% \text { in men and } 23 \% \text { in women } \\
\text { Mexico City: } 12.3 \% \text { in men and } 18.5 \% \text { in women }\end{array}$ \\
\hline NHANES (75) & $1999-2000$ & $\begin{array}{l}915 \\
\text { Mexican Americans, NHBs, } \\
\text { and NHWs }\end{array}$ & $12-19$ & IFG: $100-125$ mg/dL & $\begin{array}{l}\text { Prevalence of IFG was } 13.0,4.2 \text {, and } 7 \% \text { in Mexican } \\
\text { Americans, NHBs, and NHWs, respectively }\end{array}$ \\
\hline NHANES (76) & 1999-2002 & $\begin{array}{l}1,802 \text { adolescents without } \\
\text { DM ( } 672 \text { Mexican American) }\end{array}$ & $12-19$ & HOMA-IR & $\begin{array}{l}\text { Mexican American children had higher HOMA-IR levels } \\
\text { than white children }\end{array}$ \\
\hline NHANES (77) & $\begin{array}{l}1988-1994 \\
1999-2002\end{array}$ & $\begin{array}{l}\text { 1988-1994: 31,638 Mexican } \\
\text { American, NHW and NHB } \\
\text { adults } \\
\text { 1999-2002: 17,217 Mexican } \\
\text { American, NHW and NHB } \\
\text { adults }\end{array}$ & $\geq 20$ & $\begin{array}{l}\text { Previously diagnosed DM } \\
\text { Undiagnosed DM: } \\
\text { FPG } \geq 126 \mathrm{mg} / \mathrm{dL} \\
\text { IFG: } 100-125 \mathrm{mg} / \mathrm{dL}\end{array}$ & $\begin{array}{l}\text { Among Mexican Americans: } \\
\text { Previously diagnosed DM: } 9.6 \text { and } 10.6 \% \\
\text { Undiagnosed DM: } 4.7 \text { and } 3.5 \% \\
\text { IFG: } 32.9 \text { and } 33.0 \%\end{array}$ \\
\hline MESA (78) & 2000-2002 & 1,437 Hispanics & $45-84$ & $\begin{array}{l}\mathrm{FPG} \geq 126 \mathrm{mg} / \mathrm{dL} \text { or } \\
\text { use of hypoglycemic } \\
\text { medication }\end{array}$ & $\begin{array}{l}\text { Age-adjusted prevalence of diabetes } \\
\text { Mexican Americans: } 22.3 \% \\
\text { Dominicans: } 16.1 \% \\
\text { Puerto Ricans: } 19.7 \% \\
\text { Other Hispanics: } 15.2 \%\end{array}$ \\
\hline
\end{tabular}


TABLE 3 | Continued

\begin{tabular}{|c|c|c|c|c|c|}
\hline $\begin{array}{l}\text { Study } \\
\text { (reference) }\end{array}$ & $\begin{array}{l}\text { Study } \\
\text { period }\end{array}$ & Sample size & $\begin{array}{l}\text { Age range } \\
\text { (years) }\end{array}$ & Glycemic criteria & Key findings \\
\hline NHANES (79) & 2005-2006 & $\begin{array}{l}\text { 2,806 Mexican American, } \\
\text { NHW and NHB adults }\end{array}$ & $\geq 20$ & FPG, OGTT & $\begin{array}{l}\text { Mexican Americans } \\
\text { Diagnosed DM: } 12.6 \% \\
\text { Undiagnosed DM: } 7.5 \% \\
\text { Total DM: } 20.1 \% \\
\text { Percent undiagnosed DM: } 35.9 \% \\
\text { Prediabetes: } 32.0 \% \\
\text { Prediabetes/DM: } 52.0 \%\end{array}$ \\
\hline NHANES (80) & 2005-2006 & $\begin{array}{l}277 \text { Mexican Americans } \\
257 \text { NHBs } \\
198 \text { NHWs }\end{array}$ & $12-19$ & $\begin{array}{l}\text { FPG and 2-h OGTT } \\
\text { ADA } 1998\end{array}$ & $\begin{array}{l}\text { Prevalence of IFG, IFT, and prediabetes among Mexican } \\
\text { Americans were } 14.3,3.5 \text {, and } 16.9 \% \text {, respectively }\end{array}$ \\
\hline $\begin{array}{l}\text { Study of Women's } \\
\text { Health Across } \\
\text { the Nation } \\
\text { (SWAN) (81) }\end{array}$ & 1996-1997 & $\begin{array}{l}3,302 \text { women in seven } \\
\text { sites; analysis based on } 420 \\
\text { women recruited in the New } \\
\text { Jersey site }\end{array}$ & $42-52$ & $\begin{array}{l}\mathrm{FPG} \geq 126 \mathrm{mg} / \mathrm{dL} \text { or self- } \\
\text { reported use of insulin }\end{array}$ & $\begin{array}{l}3.3 \% \text { in Caucasians, } 5.9 \% \text { in Dominicans, } 8.3 \% \text { in } \\
\text { Central Americans, } 9.8 \% \text { in Cubans, } 13.5 \% \text { in Puerto } \\
\text { Ricans, } 15.6 \% \text { in South Americans }\end{array}$ \\
\hline $\begin{array}{l}\text { Phase I of the } \\
\text { US-Mexico } \\
\text { Border Diabetes } \\
\text { Prevention } \\
\text { and Control } \\
\text { Project (82) }\end{array}$ & 2001-2002 & $\begin{array}{l}\text { 4,027: } 2,120 \text { Hispanics from } \\
\text { Mexico, 1,437 Hispanics } \\
\text { from the US, and } 470 \text { non- } \\
\text { Hispanics from the US. }\end{array}$ & $\geq 18$ & $\begin{array}{l}\text { Self-reported diagnosis } \\
\mathrm{FPG} \geq 126 \mathrm{mg} / \mathrm{dL}\end{array}$ & $\begin{array}{l}\text { Age-adjusted prevalence of self-reported and } \\
\text { unrecognized DM was } 16.6 \% \text { of the Mexican side and } \\
14.7 \% \text { on the US side; age-adjusted prevalence of IFG } \\
\text { was similar on both sides of the border ( } 14.1 \% \text { on the } \\
\text { Mexican side and } 13.6 \% \text { on the US side) }\end{array}$ \\
\hline BRFSS (83) & 1995-2010 & $\begin{array}{l}\text { 1995: } 1,193 \text { in Montana to } \\
5,107 \text { in Maryland } \\
\text { 2010: } 1,964 \text { in Alaska to } \\
35,109 \text { in Florida }\end{array}$ & $\geq 18$ & Self-reported diagnosis & $\begin{array}{l}\text { In 1995, age-adjusted prevalence was > } 6 \% \text { in only three } \\
\text { states, Washington, DC, and Puerto Rico. } \\
\text { In } 2010 \text {, age-adjusted prevalence was highest (>10\%) } \\
\text { in Alabama, Mississippi, Puerto Rico, South Carolina, } \\
\text { Tennessee, Texas, and West Virginia. }\end{array}$ \\
\hline NHANES (85) & 1999-2008 & $\begin{array}{l}22,621 \text { Mexican American, } \\
\text { NHW and NHB adults, of } \\
\text { whom } 551 \text { had undiagnosed } \\
\text { DM }\end{array}$ & $\geq 20$ & $\begin{array}{l}\text { Undiagnosed DM was } \\
\text { defined as } \mathrm{HbA} 1 \mathrm{c} \geq 6.5 \% \\
\text { without a self-report of } \\
\text { physician-diagnosed DM }\end{array}$ & $\begin{array}{l}\text { Overall prevalence of undiagnosed DM of } 1.5 \% \text { in } \\
\text { NHWs, } 3.1 \% \text { in NHBs, and } 2.7 \% \text { in Mexican } \\
\text { Americans } \\
\text { Overall prevalence of diagnosed DM of } 6.7 \% \text { in } \\
\text { NHWs, } 11.3 \% \text { in NHBs, and } 7.6 \% \text { in Mexican } \\
\text { Americans }\end{array}$ \\
\hline $\begin{array}{l}\text { California Health } \\
\text { Interview } \\
\text { Survey (86) }\end{array}$ & $\begin{array}{l}2001, \\
2003, \\
2005, \text { and } \\
2007\end{array}$ & $\begin{array}{l}\text { 33,633 Hispanics and } \\
126,488 \text { NHWs }\end{array}$ & $\geq 18$ & $\begin{array}{l}\text { Self-report of physician- } \\
\text { diagnosed DM }\end{array}$ & $\begin{array}{l}\text { Mexicans: } 9 \% \\
\text { Central Americans: } 1 \% \\
\text { South Americans: } 0.5 \% \\
2 \text { or more countries of origin: } 7 \% \\
\text { Other Hispanics: } 13 \% \\
\text { NHWs: } 7 \%\end{array}$ \\
\hline NHANES (87) & $\begin{array}{l}1999-2002 \\
2003-2006 \\
2007-2010\end{array}$ & $\begin{array}{l}\text { 19,182 Mexican American, } \\
\text { NHW and NHB adults }\end{array}$ & $\geq 12$ & $\begin{array}{l}\text { HbA1c: } 5.7-6.4 \% \\
\text { FPG: } 100-125 \mathrm{mg} / \mathrm{dL}\end{array}$ & $\begin{array}{l}\text { Prevalence of prediabetes among Mexican Americans: } \\
34.4,30.3 \text {, and } 37.8 \%\end{array}$ \\
\hline $\begin{array}{l}\mathrm{HCHS} / \mathrm{SOL} \\
(12,84)\end{array}$ & 2008-2011 & 16,415 Hispanics & $18-74$ & FPG, 2-h OGTT, HbA1c & $\begin{array}{l}\text { Overall prevalence of DM was } 16.9 \% \\
\text { South Americans: } 10.2 \% \\
\text { Cubans: } 13.4 \% \\
\text { Central Americans: } 17.7 \% \\
\text { Dominicans: } 18.1 \% \\
\text { Puerto Ricans: } 18.1 \% \\
\text { Mexicans/Mexican Americans: } 18.3 \%\end{array}$ \\
\hline $\begin{array}{l}\text { SEARCH } \\
\text { Study }(88,89)\end{array}$ & 2001-2009 & $\begin{array}{l}3,345,783 \text { youths in } 2001 \\
\text { and } 3,458,974 \text { in } 2009\end{array}$ & $<20$ & Physician-diagnosed DM & $\begin{array}{l}\text { Prevalence of type } 2 \text { DM among Hispanic youth aged } \\
10-19 \text { years was } 0.45 \text { per } 1,000 \text { in } 2001 \text { and } 0.79 \text { per } \\
1,000 \text { in } 2009 \text {, representing a relative increase of } 76 \% \\
\text { over the } 8 \text {-year period }\end{array}$ \\
\hline NHANES (90) & $\begin{array}{l}1988-1994 \\
1999-2004 \\
2005-2010\end{array}$ & $\begin{array}{l}\text { 1988-1994: 4,201 } \\
\text { 1999-2004: 2,860 } \\
\text { 2005-2010: 2,765 } \\
\text { Mexican Americans }\end{array}$ & $\geq 20$ & Based on $\mathrm{HbA} 1 \mathrm{c}$ & $\begin{array}{l}\text { Diagnosed DM: } 7.6(0.57), 8.8(1.06), 11.9(1.01) \\
\text { Undiagnosed DM: } 1.8(0.17), 2.3(0.40), 2.9(0.32) \\
\text { Prediabetes: } 5.6(0.64), 10.6(0.68), 12.7(0.76)\end{array}$ \\
\hline
\end{tabular}


TABLE 3 | Continued

\begin{tabular}{|c|c|c|c|c|c|}
\hline $\begin{array}{l}\text { Study } \\
\text { (reference) }\end{array}$ & $\begin{array}{l}\text { Study } \\
\text { period }\end{array}$ & Sample size & $\begin{array}{l}\text { Age range } \\
\text { (years) }\end{array}$ & Glycemic criteria & Key findings \\
\hline NHANES (8) & $1988-2012$ & $\begin{array}{l}\text { 2011-2012: 2,623 (561 All } \\
\text { Hispanics) }\end{array}$ & $\geq 20$ & $\begin{array}{l}\text { Self-reported diagnosis } \\
\text { Undiagnosed DM based } \\
\text { on FPG, 2-h OGTT, } \\
\text { HbA1c }\end{array}$ & $\begin{array}{l}\text { All Hispanics } \\
\text { Total DM: 22.6\% } \\
\text { Diagnosed DM: } 12.5 \% \\
\text { Undiagnosed DM: 10.1\% } \\
\text { Prediabetes: 36.8\% } \\
\text { Mexican Americans } \\
\text { Total DM: } 23.8 \% \\
\text { Diagnosed DM: 14.4\% } \\
\text { Undiagnosed DM: } 9.4 \% \\
\text { Prediabetes: } 38.0 \%\end{array}$ \\
\hline NHIS (91) & 1997-2012 & $\begin{array}{l}427,975 \text { (367,292 non- } \\
\text { Hispanics and 60,683 } \\
\text { Hispanics) }\end{array}$ & $\geq 18$ & Self-reported diagnosis & $\begin{array}{l}\text { Less than high school education: } 17.6 \% \text { for Puerto } \\
\text { Ricans, } 13.4 \% \text { for Cubans, and } 9.7 \% \text { for Mexicans } \\
\text { High school diploma/GED: } 9.8 \% \text { for Puerto Ricans, } \\
8.2 \% \text { for Cubans, and } 6.3 \% \text { for Mexicans } \\
\text { More than high school education: } 6.8 \% \text { for Puerto } \\
\text { Ricans, } 6.0 \% \text { for Cubans, and } 6.7 \% \text { for Mexicans }\end{array}$ \\
\hline HCHS/SOL (13) & 2008-2011 & 15,507 Hispanics & $18-74$ & FPG, 2-h OGTT, HbA1c & $\begin{array}{l}6.7 \% \text { met at least one diagnostic criterion of } \\
\text { probable DM }-39.4 \% \text { of total DM (self-reported } \\
\text { plus probable DM) }\end{array}$ \\
\hline HCHS/SOL (92) & 2012-2014 & 1,466 Hispanics & $8-16$ & $\begin{array}{l}\text { FPG and HbA1c } \\
\text { ADA } 2015\end{array}$ & $\begin{array}{l}\text { Prevalence of prediabetes/DM was } 16.5 \% \text {, being higher } \\
\text { in boys }(20.9 \%) \text { than in girls }(11.8 \%)\end{array}$ \\
\hline $\begin{array}{l}\text { Starr County, } \\
\text { Texas (93) }\end{array}$ & $2002-2014$ & $\begin{array}{l}5,230 \text { Mexican American } \\
\text { adults }\end{array}$ & $\geq 20$ & FPG, OGTT, HbA1c & $\begin{array}{l}\text { Previously identified DM: } 11.8 \% \text { in men and } 14.4 \% \text { in } \\
\text { women } \\
\text { Newly identified DM: } 11.9 \% \text { in men and } 12.3 \% \text { in } \\
\text { women } \\
\text { Total DM: } 23.7 \% \text { in men and } 26.7 \% \text { in women } \\
\text { Prediabetes: } 32.8 \% \text { in men and } 31.9 \% \text { in women }\end{array}$ \\
\hline NHANES (94) & 2005-2014 & $\begin{array}{l}2,606 \mathrm{NHWs}, \mathrm{NHBs} \text {, and } \\
\text { Hispanics }\end{array}$ & $12-19$ & FPG, 2-h OGTT, HbA1c & $\begin{array}{l}\text { Prevalence of total DM, prediabetes, and percent } \\
\text { undiagnosed DM: } \\
\text { All Hispanics: 0.76, } 22.9 \text {, and } 39.5 \% \\
\text { Mexican Americans: } 0.85,22.4 \text {, and } 43.9 \%\end{array}$ \\
\hline HCHS/SOL (95) & 2008-2011 & 15,507 Hispanics & $18-74$ & FPG, 2-h OGTT, HbA1c & $\begin{array}{l}\text { Prediabetes: } 36.3 \% \\
\text { Total IFG: } 18.1 \% \\
\text { Total IGT: } 15.4 \% \\
\text { Total impaired HbA1c: } 21.2 \% \\
\text { IFG + impaired HbA1c: } 8.6 \% \\
\text { IFG + IGT + impaired HbA1c: } 3.8 \%\end{array}$ \\
\hline
\end{tabular}

(92), with boys having a higher prevalence compared with girls ( 20.9 vs. $11.8 \%$, respectively). However, the study did not assess differences by Hispanic/Latino heritage group nor was OGTT available.

The limited number of studies examining the incidence of type 2 DM in Hispanic/Latinos (99-106) indicates that the incidence has been higher than in NHWs across all age groups (99-101) (Table 4). A recent analysis of type 2 DM in children examined in five study centers in the U.S (105) reported an annual rate increase significantly greater for Hispanics/Latinos (3.1\%) compared to NHWs $(0.6 \%)$, but significantly lower than Native Americans (8.9\%). However, a recent analysis based on NHANES 2005-2014 cycle did not reveal an increase in incidence in this age group (94).

A few studies have estimated GDM in Hispanics/Latinos (107-114) (Table 5). One of the early studies examining the epidemiology of GDM in an ethnically diverse cohort of over
10,000 women at the Mount Sinai Medical Center in New York City between 1987 and 1990 found a prevalence of 3.2\% (107). After controlling for traditional risk factors, first-generation Hispanic/Latino women had a 59\% increased risk for GDM compared to NHW women. Kim et al. (112) found that among Hispanic/Latino women, the prevalence of GDM varied by heritage group, from $5.5 \%$ among Cubans to $8.7 \%$ among Mexicans. Nearly $45 \%$ of GDM cases among Hispanic/Latino women were attributable to overweight and obesity, which ranged from $38.5 \%$ among Central/South American women to $65.7 \%$ among Cuban women. In a recent study of prevalence trends in GDM by race/ethnicity for 19 states, the GDM prevalence increased significantly from 3.71 per 100 deliveries in 2000 to 5.77 per 100 deliveries in 2010 (113). Prevalence of GDM among deliveries increased significantly among all racial/ethnic groups, particularly Hispanics/Latinas, who experienced the highest relative increase $(66 \%)$. 
TABLE 4 | Incidence of type 2 diabetes among Hispanic/Latino populations in the US (selected studies).

\begin{tabular}{|c|c|c|c|c|c|}
\hline $\begin{array}{l}\text { Study and } \\
\text { reference }\end{array}$ & $\begin{array}{l}\text { Study } \\
\text { period }\end{array}$ & Sample size & $\begin{array}{l}\text { Age range } \\
\text { (years) }\end{array}$ & Glycemic criteria & Key findings \\
\hline $\begin{array}{l}\text { San Antonio Heart } \\
\text { Study, Texas (99) }\end{array}$ & 1979-1992 & $\begin{array}{l}\text { 3,302 Mexican } \\
\text { Americans }\end{array}$ & $25-64$ & 2-h OGTT & $\begin{array}{l}\text { 8-year incidence was } 8.7 \% \text { among Mexican Americans in the low-income } \\
\text { barrio neighborhoods; } 8.4 \% \text { among Mexican Americans in the transitional } \\
\text { neighborhoods; and } 3.4 \% \text { among Mexican Americans in the suburban } \\
\text { neighborhoods }\end{array}$ \\
\hline $\begin{array}{l}\text { San Luis Valley } \\
\text { Diabetes Study, } \\
\text { Colorado (100) }\end{array}$ & 1983-1988 & $\begin{array}{l}607 \text { Hispanics } \\
\text { without prior } \\
\text { history of DM } \\
343 \text { Hispanics } \\
\text { with previously } \\
\text { diagnosed DM }\end{array}$ & $20-74$ & $\begin{array}{l}\text { History of previously } \\
\text { diagnosed DM with } \\
\text { confirmation using } \\
\text { FPG } \geq 140 \mathrm{mg} / \mathrm{dL} \text { or } 2-\mathrm{h} \\
\text { OGTT } \geq 200 \mathrm{mg} / \mathrm{dL}\end{array}$ & $\begin{array}{l}\text { 6-year incidence for Hispanic men and women was } 4.3 / 1,000 \text { and } \\
5.3 / 1,000 \text {, respectively; incidence was } 2.4(95 \% \mathrm{Cl} \text { : } 1.6-3.6) \text { times higher } \\
\text { in Hispanic men than in NHW men; incidence in Hispanic women was } 3.6 \\
(95 \% \mathrm{Cl}: 2.4-5.4) \text { times higher. }\end{array}$ \\
\hline $\begin{array}{l}\text { San Antonio } \\
\text { Heart Study, } \\
\text { Texas (101) }\end{array}$ & 1987-1996 & $\begin{array}{l}\text { 1,995 Mexican } \\
\text { Americans } \\
\text { 1,231 } \mathrm{NHWs}\end{array}$ & $25-64$ & $\begin{array}{l}2-\mathrm{h} O \mathrm{OGTT} \geq 200 \mathrm{mg} / \mathrm{dL} \\
\mathrm{FPG} \geq 126 \mathrm{mg} / \mathrm{dL} \\
\text { History of } \mathrm{DM} \text { and } \\
\text { receiving treatment } \\
\text { with insulin or oral } \\
\text { hypoglycemic agents }\end{array}$ & $\begin{array}{l}\text { 7- to 8-year incidence increased from 5.7\% for Mexican Americans } \\
\text { enrolled in } 1979 \text { to } 15.7 \% \text { for participants enrolled in } 1988 .\end{array}$ \\
\hline $\begin{array}{l}\text { San Antonio } \\
\text { Heart Study, } \\
\text { and Mexico City } \\
\text { Diabetes Study } \\
(102)\end{array}$ & 1987-1996 & $\begin{array}{l}\text { 1,995 Mexican } \\
\text { Americans } \\
\text { 1,231 } \mathrm{NHWs}\end{array}$ & $35-64$ & $\begin{array}{l}2-\mathrm{h} O G T \mathrm{~T} \geq 200 \mathrm{mg} / \mathrm{dL} \\
\mathrm{FPG} \geq 126 \mathrm{mg} / \mathrm{dL} \\
\text { History of } \mathrm{DM} \text { and } \\
\text { receiving treatment } \\
\text { with insulin or oral } \\
\text { hypoglycemic agents }\end{array}$ & $\begin{array}{l}\text { 6- to } 8 \text {-year crude incidence was } 90 \% \text { higher in Mexican Americans } \\
\text { men living in San Antonio than Mexicans in Mexico City: } 2.70 / 100 \text { versus } \\
1.42 / 100 \text {; in women, the crude incidence was more than twofold higher } \\
\text { in San Antonio than in Mexico City: } 2.86 / 100 \text { versus } 1.21 / 100 \text {. Incidence } \\
\text { remained significantly higher in San Antonio than in Mexico City after } \\
\text { adjusting for several confounders. }\end{array}$ \\
\hline $\begin{array}{l}\text { SEARCH for } \\
\text { Diabetes in Youth } \\
\text { Study, US (103) }\end{array}$ & 2002-2005 & $\begin{array}{l}635 \text { incident } \\
\text { cases from } \\
3,207,005 \\
\text { Hispanic } \\
\text { person-years } \\
\text { at risk }\end{array}$ & $<20$ & Physician-diagnosed DM & $\begin{array}{l}\text { Incidence of type } 1 \mathrm{DM} \text { for youth aged } \leq 14 \text { years was } 15.0 / 100,000 \\
\text { for females and } 16.2 / 100,000 \text { for males. Among youth aged } \leq 17 \text { years, } \\
\text { the rates of type } 1 \mathrm{DM} \text { were } 14.1 / 100,000 \text { for females and } 15.6 / 100,000 \\
\text { for males. For type } 2 \mathrm{DM} \text {, the rates were } 6.9 / 100,000 \text { for females and } \\
4.8 / 100,000 \text { for males. }\end{array}$ \\
\hline $\begin{array}{l}\text { Puerto Rico Heart } \\
\text { Health Program } \\
(104)\end{array}$ & 1965-1975 & $\begin{array}{l}4,685 \text { Puerto } \\
\text { Ricans }\end{array}$ & $35-79$ & $\begin{array}{l}\text { FPG } \geq 126 \mathrm{mg} / \mathrm{dL} \text { and } \\
\text { self-reports of physician- } \\
\text { diagnosed diabetes or use } \\
\text { of insulin or hypoglycemic } \\
\text { agents }\end{array}$ & $\begin{array}{l}\text { Crude rate of } 11 \% \text { over a median follow-up period of } 2.6 \text { years (range: } \\
2-7 \text { years), for an incidence rate of } 42.6 / 1,000 \text { person-years. }\end{array}$ \\
\hline $\begin{array}{l}\text { New York City } \\
\text { Community } \\
\text { Health Survey } \\
\text { (105) }\end{array}$ & $\begin{array}{c}2002, \\
2004, \text { and } \\
2008\end{array}$ & 24,384 & $\geq 18$ & Self-reported DM & $\begin{array}{l}\text { Age-adjusted incidence of DM per 1,000 population was } 9.4 \text { in } 2002 \text {, } \\
11.9 \text { in } 2004 \text {, and } 8.6 \text { in } 2008 \text {. DM incidence was significantly associated } \\
\text { with being aged } 45 \text { or older, being Black or Hispanic, being overweight or } \\
\text { obese, and having less than a high school diploma. }\end{array}$ \\
\hline $\begin{array}{l}\text { SEARCH for } \\
\text { Diabetes in Youth } \\
\text { Study, US (106) }\end{array}$ & 2002-2012 & $\begin{array}{l}11,245 \text { youths } \\
\text { aged }<20 \text { with } \\
\text { type } 1 \mathrm{DM} \text { and } \\
2,846 \text { youth } \\
\text { aged } 10-19 \\
\text { with type } 2 \\
\text { diabetes }\end{array}$ & $<20$ & Physician-diagnosed DM & $\begin{array}{l}\text { Annual rate of increase in type } 1 \mathrm{DM} \text { was greater among Hispanics than } \\
\text { among NHWs ( } 4.2 \text { vs. } 1.2 \%, P<0.001) \text {. Annual rate of increase in type } \\
2 \text { DM among Hispanics differed significantly from that among Native } \\
\text { Americans }(3.1 \% \text { vs. } 8.9 \%, P=0.01) \text {. }\end{array}$ \\
\hline
\end{tabular}

\section{Diabetes in Latin America}

Table 6 illustrates selected studies assessing diabetes in Latin America (115-139). The prevalence of diabetes varies by date in which the studies were performed, methods of assessing prevalence, region and age group $(140,141)$.

According to a 2015 International Diabetes Federation report, the prevalence of type $2 \mathrm{DM}$ in Latin America was highest in Mexico (14.7\%) and lowest in Argentina (6.2\%); however, over one-quarter of the Latin American and Caribbean population remained undiagnosed (141). The Cardiovascular Risk Factor Multiple Evaluation in Latin America (CARMELA) Study (conducted between 2003 and 2005) (128) reported an age-adjusted prevalence of diabetes of $7.0 \%$ in seven urban populations in Latin America (129). The prevalence was highest in Mexico City, Mexico (8.9\%) and Bogotá, Colombia (8.1\%) and lowest in Lima, Perú (4.4\%); it increased with age in all cities, and tended to be higher among women than men. Prevalence of undiagnosed diabetes occurred in $20 \%$ of adults with diabetes. The Latin American Consortium of Studies in Obesity (LASO) (which included 11 studies conducted in eight countries between 1999 and 2008) (132) reported an average prevalence of $5 \%$, which increased from $0.9 \%$ in participants aged $20-29$ years to $16.4 \%$ in those aged 70 or older (133). However, the prevalence of diabetes in Latin America and 
TABLE 5 | Incidence or prevalence of gestational diabetes mellitus among Hispanic/Latino populations in the US.

\begin{tabular}{|c|c|c|c|c|c|}
\hline Study and reference & $\begin{array}{l}\text { Study } \\
\text { period }\end{array}$ & Sample size & $\begin{array}{l}\text { Age range } \\
\text { (years) }\end{array}$ & Glycemic criteria & Key findings \\
\hline New York City (107) & 1987-1989 & $\begin{array}{l}\text { 10,187 (328 with } \\
\text { GDM; of these } \\
112 \text { Hispanic) }\end{array}$ & $<20$ to $\geq 40$ & $\begin{array}{l}\text { FPG and OGTT according to } \\
\text { National Diabetes Data Group }\end{array}$ & $\begin{array}{l}\text { Prevalence of } 4.1 \% \text { among Hispanics Excess risk for } \\
\text { Hispanic women born in Puerto Rico or elsewhere } \\
\text { outside of the US }\end{array}$ \\
\hline $\begin{array}{l}\text { Nurses' Health Study II } \\
\text { (108) }\end{array}$ & 1990-1994 & $\begin{array}{l}14,613(224 \\
\text { Hispanic) }\end{array}$ & $25-42$ & $\begin{array}{l}\text { Self-reported GDM, validated } \\
\text { by medical record review in a } \\
\text { subset }\end{array}$ & $\begin{array}{l}\text { 4.7\% Whites, } 10.6 \% \text { AAs, } 7.6 \% \text { Hispanics, and } 10.5 \% \\
\text { Asians }\end{array}$ \\
\hline $\begin{array}{l}\text { Northern California Kaiser } \\
\text { Permanente Medical Care } \\
\text { Program (109) }\end{array}$ & 1991-2000 & $\begin{array}{l}267,051 \\
\text { pregnancies } \\
\text { screened for GDM }\end{array}$ & $15-49$ & $\begin{array}{l}\text { Physician diagnosis or ADA } \\
\text { criteria }\end{array}$ & $\begin{array}{l}\text { Age- and race/ethnicity-adjusted yearly prevalence } \\
\text { increased from } 5.1 \% \text { in } 1991 \text { to } 7.4 \% \text { in } 1997 \text {, being } \\
\text { significantly higher among Asians (7.2-11.0\%) and } \\
\text { Hispanics (7.2-9.8\%) }\end{array}$ \\
\hline New York City (110) & 1995-2003 & 951,920 & $15-44$ & $\begin{array}{l}\text { Diagnostic codes ICD-9 } \\
648.81-648.82\end{array}$ & $\begin{array}{l}\text { Overall risk of } 5.2 \% \\
\text { 7.2\% North African } \\
\text { 5.9\% Sub-Saharan Africa } \\
\text { 6.2\% East Asia } \\
\text { 8.6\% South-East Asia and Pacific Islands } \\
\text { 14.3\% South Central Asia } \\
\text { 6.8\% Non-Hispanic Caribbean } \\
\text { 4.9\% Hispanic Caribbean } \\
\text { 6.3\% Mexico } \\
\text { 4.9\% Central American } \\
\text { 6.6\% South American } \\
\text { 34.3\% African-American } \\
\text { 3.6\% NHWs }\end{array}$ \\
\hline 19 US states (111) & 2005-2006 & $3,108,877$ births & $<20$ to $\geq 40$ & Documented in birth certificate & $\begin{array}{l}\text { 3.8\% NHWs, 3.5\% NHBs, 3.6\% Hispanics, 6.3\% Asian, } \\
\text { and Pacific Islanders }\end{array}$ \\
\hline \multirow[t]{2}{*}{ California (112) } & 2007-2009 & $1,228,265$ records & $\geq 20$ & $\begin{array}{l}\text { ICD-9-CM codes for } \\
\text { pregestational DM (250) or DM } \\
(648.0)\end{array}$ & $\begin{array}{l}\text { 11.9\% Asian and Pacific Islands, } 7.6 \% \text { American Indians, } \\
\text { 5.6\% Black Americans, } 8.4 \% \text { Hispanics, } 6.6 \% \text { others, } \\
\text { and } 5.4 \% \text { NHWs }\end{array}$ \\
\hline & & & & $\begin{array}{l}\text { GDM was defined as glucose } \\
\text { intolerance complicating } \\
\text { pregnancy, childbirth, or } \\
\text { postpartum (ICD-9-CM } \\
\text { code 648.8). }\end{array}$ & $\begin{array}{l}\text { Among Hispanic women: Mexican (8.7\%), Central/South } \\
\text { American (7.4\%), Puerto Rican (6.6\%), and Cuban (5.5\%) }\end{array}$ \\
\hline $\begin{array}{l}\text { GDM among hospital } \\
\text { deliveries in } 19 \text { US states } \\
(113)\end{array}$ & 2000-2010 & $\begin{array}{l}75,212 \text { in } 2000 \text { to } \\
119,229 \text { in } 2010\end{array}$ & $15-44$ & $\begin{array}{l}\text { ICD-9-CM 648.8x, DRG codes } \\
767-768,774-775, \text { and } \\
\text { 765-766 (2008-2010), } \\
\text { or DRG codes 370-375 } \\
\text { (2000-2007) }\end{array}$ & $\begin{array}{l}\text { Age-standardized prevalence increased from } 3.71 \% \text { in } \\
2000 \text { to } 5.77 \% \text { in } 2010 \\
\text { Largest relative increase in prevalence was highest } \\
\text { among Hispanics (66\%) }\end{array}$ \\
\hline $\begin{array}{l}\text { Prepregnancy diabetes } \\
\text { among deliveries in } 19 \text { US } \\
\text { states (114) }\end{array}$ & 2000-2010 & $\begin{array}{l}13,217 \text { in } 2000 \text { to } \\
18,168 \text { in } 2010\end{array}$ & $15-44$ & $\begin{array}{l}\text { ICD-9-CM 648.0x. } 250 . \\
\text { xx, or 249.xx or DRG codes } \\
767-768,774-775, \text { and } \\
\text { 765-766 (2007-2010) or DRG } \\
\text { codes 372-375 (2000-2007) }\end{array}$ & $\begin{array}{l}\text { Age-standardized prevalence of deliveries with } \\
\text { prepregnancy DM among Hispanics ranged from } 0.74 \text { in } \\
2000 \text { to } 0.94 \text { in } 2010 \\
\text { NHBs, followed by Hispanics, had the highest absolute } \\
\text { change in age-standardized rates ( } 0.20 \text { per } 100 \\
\text { deliveries) and throughout the time period had the } \\
\text { highest rates of prepregnancy DM }\end{array}$ \\
\hline
\end{tabular}

ICD-9, International Classification of Diseases, Ninth Version; ICD-9-CM, International Classification of Diseases, Ninth Version, Clinical Modification. DRG, Diagnosis-Related Group.

the Caribbean was similar to the US population (NHANES, 1999-2004), after accounting for differences in the age distribution. Puerto Rico had the highest prevalence among the countries included in the analysis.

More recent Latin American studies include the Estudo Longitudinal de Saúde do Adulto (ELSA-Brasil) (134), which reported a prevalence of $19.7 \%$ (based on self-report or FPG, $2 \mathrm{hPG}$ and $\mathrm{HbA1c}$ ), of which about half was undiagnosed (135); the Centro de Excelencia en Salud Cardiovascular para el Cono Sur I (CESCAS I), which reported an overall prevalence (based on FPG only) of $12.4 \%$ across four sites in Argentina, Chile, and Uruguay (136); and the Centro de Excelencia de Enfermedades Crónicas (CRONICAS), which reported an overall prevalence of 7.1\% (based on FPG only) across four regions in Perú (139).

One of the few studies in Latin America and the Caribbean that estimated the incidence of type $2 \mathrm{DM}$ is the Mexico City Diabetes Study, which focused on the population aged 35-64 years over 18 years of follow-up (143) (Table 7). Cumulative incidence rates of type $2 \mathrm{DM}$ for men and women were 14.4/1,000 and $13.7 / 1,000$, respectively. Incidence was $15.8,15.7$, and 12.7 per 
TABLE 6 | Prevalence of type 2 diabetes and prediabetes among Hispanic/Latino populations in Latin America (selected studies).

\begin{tabular}{|c|c|c|c|c|c|}
\hline Study and reference & $\begin{array}{l}\text { Study } \\
\text { period }\end{array}$ & Sample size & $\begin{array}{l}\text { Age range } \\
\text { (years) }\end{array}$ & Glycemic criteria & Key findings \\
\hline $\begin{array}{l}\text { The Brazilian Cooperative Group } \\
\text { on the Study of Diabetes } \\
\text { Prevalence (115) }\end{array}$ & $1986-1988$ & $\begin{array}{l}21,847 \text { from nine large } \\
\text { cities }\end{array}$ & 30-69 & $\begin{array}{l}\text { 2-h OGTT } \\
\text { WHO } 1985\end{array}$ & $\begin{array}{l}\text { Overall prevalence was } 7.6 \text { and } 7.8 \% \\
\text { for diabetes and IGT, respectively. DM } \\
\text { prevalence increased from } 2.7 \% \text { in the } \\
\text { 30-39-year age-group to } 17.4 \% \text { in the } \\
60-69 \text {-year age-group }\end{array}$ \\
\hline $\begin{array}{l}\text { The Cooperative Group for the } \\
\text { Study of Diabetes Prevalence } \\
\text { in Rio de Janeiro, Brazil (116) }\end{array}$ & 1988-1989 & 2,051 & $30-69$ & $\begin{array}{l}\text { 2-h OGTT } \\
\text { WHO } 1985\end{array}$ & $\begin{array}{l}\text { Age-adjusted prevalence rates for DM } \\
\text { and IGT were } 7.1 \text { and } 9.0 \% \text {, respectively }\end{array}$ \\
\hline Bolivia (117) & 1998 & $\begin{array}{l}\text { 2,948 from four Bolivian } \\
\text { cities: La Paz, El } \\
\text { Alto, Santa Cruz, and } \\
\text { Cochabamba }\end{array}$ & $\geq 25$ & $\begin{array}{l}\text { 2-h OGTT } \\
\text { WHO } 1997\end{array}$ & $\begin{array}{l}\text { Overall prevalence of DM was } 7.2 \% \text { and } \\
\text { of IGT was } 7.8 \% \text {. }\end{array}$ \\
\hline $\begin{array}{l}\text { Brazilian Multicenter Study, Ribeirão } \\
\text { Preto, São Paulo, Brazil (118) }\end{array}$ & $1986-1988$ & 1,473 & $30-69$ & $\begin{array}{l}\text { 2-h OGTT } \\
\text { WHO } 1997\end{array}$ & $\begin{array}{l}\text { The overall rates of DM and IGT were } \\
12.1 \text { and } 7.7 \% \text {, respectively }\end{array}$ \\
\hline $\begin{array}{l}\text { Mexican National Health Survey } \\
2000 \text { (119) }\end{array}$ & 2000 & $\begin{array}{l}42,886 \text { from } 400 \text { cities } \\
\text { in Mexico }\end{array}$ & $\geq 20$ & $\begin{array}{l}\text { 2-h OGTT } \\
\text { FBG } \\
\text { ADA } 1997\end{array}$ & $\begin{array}{l}\text { Age-adjusted prevalence } 8.2 \% \text {, of } \\
\text { which } 2,878 \text { ( } 80 \%) \text { had previously been } \\
\text { diagnosed. }\end{array}$ \\
\hline Argentina (120) & $1995-1998$ & 2,397 & $\geq 20$ & $\begin{array}{l}\text { 2-h OGTT } \\
\text { WHO } 1999\end{array}$ & $\begin{array}{l}\text { Age-standardized prevalence rates for } \\
\text { diabetes ranged between } 6.5 \text { and } 7.7 \%\end{array}$ \\
\hline $\begin{array}{l}\text { Mexican National Health Survey } \\
2000 \text { (121) }\end{array}$ & 2000 & $\begin{array}{l}12,856 \text { men and } \\
28,332 \text { women }\end{array}$ & $20-69$ & $\begin{array}{l}\text { 2-h OGTT } \\
\text { FBG } \\
\text { ADA } 1997\end{array}$ & $\begin{array}{l}\text { DM rates of } 5.6 \% \text { in men and } 9.7 \% \text { in } \\
\text { women }\end{array}$ \\
\hline $\begin{array}{l}\text { The Health Wellbeing and Aging } \\
\text { (SABE) Project and NHANES (123) }\end{array}$ & 1999-2004 & 10,518 & $\geq 60$ & Self-reported diagnosis & $\begin{array}{l}\text { 13.0\% in Santiago, } 13.8 \% \text { in Montevideo, } \\
\text { 14.7\% in Havana, } 17.7 \% \text { in São } \\
\text { Paulo, } 21.3 \% \text { in Mexico City, } 21.7 \% \text { in } \\
\text { Bridgetown } \\
\text { US Whites } 13.8 \% \\
\text { US Blacks } 25.5 \% \\
\text { US Mexican Americans } 26.4 \%\end{array}$ \\
\hline $\begin{array}{l}\text { The Health Wellbeing and Aging } \\
\text { (SABE) Project (124) }\end{array}$ & 1999-2000 & 13,753 & $\geq 60$ & Self-reported diagnosis & $\begin{array}{l}\text { Prevalence of diagnosed diabetes was } \\
\text { highest in US Blacks and Mexican } \\
\text { Americans, followed by Bridgetown and } \\
\text { Mexico City ( } 22 \% \text { for each) and lowest in } \\
\text { Santiago, Montevideo, Havana, and US } \\
\text { Whites (13-15\%). }\end{array}$ \\
\hline The FRIMEX Study (125) & 2001-2002 & $\begin{array}{l}\text { 140,017 from } 6 \text { Mexican } \\
\text { cities: Mexico City, } \\
\text { Guadalajara, Monterrey, } \\
\text { Puebla, Leon, and } \\
\text { Tijuana }\end{array}$ & $\geq 18$ & $\begin{array}{l}\mathrm{FBG}>126 \mathrm{mg} / \mathrm{dL} \\
\text { Random }>200 \mathrm{mg} / \mathrm{dL}\end{array}$ & Prevalence of $10.4 \%$ \\
\hline $\begin{array}{l}\text { PREVENCION } \\
\text { Peruvian Study of the Prevalence } \\
\text { of Cardiovascular Diseases (126) }\end{array}$ & 2004-2006 & $\begin{array}{l}1,878 \text { adults in } \\
\text { Arequipa, Peru }\end{array}$ & $20-80$ & $\begin{array}{l}\mathrm{FPG} \geq 100 \mathrm{mg} / \mathrm{dL} \text { or current } \\
\text { antidiabetic medication } \\
\text { (insulin or oral agents) }\end{array}$ & $\begin{array}{l}\text { Age-standardized prevalence was } 6.3 \% \\
\text { in men and } 5.9 \% \text { in women }\end{array}$ \\
\hline $\begin{array}{l}\text { Pelotas, Rio Grande do Sul State, } \\
\text { Brazil (127) }\end{array}$ & 2003 & $\begin{array}{l}3,100 \text { men } \\
\text { and women }\end{array}$ & $\geq 20$ & Self-reported diagnosis & Prevalence of DM of $6.3 \%$ \\
\hline CARMELA Study (128) & 2003-2005 & $\begin{array}{l}11,550 \text { in } 7 \text { Latin } \\
\text { American countries }\end{array}$ & $25-64$ & $\begin{array}{l}\mathrm{FPG} \geq 126 \mathrm{mg} / \mathrm{dL} \text { or self- } \\
\text { reported diagnosis }\end{array}$ & Prevalence of DM was 7\% (range: 4-9\%) \\
\hline CARMELA Study (129) & 2003-2005 & $\begin{array}{l}11,502 \text { in } 7 \text { Latin } \\
\text { American countries }\end{array}$ & $25-64$ & $\begin{array}{l}\mathrm{FPG} \geq 110 \mathrm{mg} / \mathrm{dL} \text { or self- } \\
\text { reported diagnosis }\end{array}$ & $\begin{array}{l}31.2 \% \text { had glucose abnormalities }(32.6 \% \\
\text { of men and } 30.1 \% \text { of women) }\end{array}$ \\
\hline $\begin{array}{l}\text { Mexico City Prospective } \\
\text { Study (130) }\end{array}$ & 1998-2004 & $\begin{array}{l}52,584 \text { men and } \\
106,962 \text { women }\end{array}$ & $\geq 35$ & Self-reported diagnosis & $4.8 \%$ in men and $3.9 \%$ in women \\
\hline Chile (131) & 2000-2005 & $\begin{array}{l}486 \text { overweight and } \\
\text { obese adolescents }\end{array}$ & $6-15$ & $\mathrm{FPG} \geq 100 \mathrm{mg} / \mathrm{dL}$ & $\begin{array}{l}2 \% \text { in males Tanner stage I-II } \\
1 \% \text { in females Tanner stage I-II } \\
9 \% \text { in males Tanner stage III-V } \\
6 \% \text { in females Tanner stage III-V }\end{array}$ \\
\hline
\end{tabular}


TABLE 6 | Continued

\begin{tabular}{|c|c|c|c|c|c|}
\hline Study and reference & $\begin{array}{l}\text { Study } \\
\text { period }\end{array}$ & Sample size & $\begin{array}{l}\text { Age range } \\
\text { (years) }\end{array}$ & Glycemic criteria & Key findings \\
\hline $\begin{array}{l}\text { The Latin American Consortium of } \\
\text { Studies in Obesity (LASO) (133) }\end{array}$ & 1998-2007 & $\begin{array}{l}31,009 \\
\text { Argentina, Chile, } \\
\text { Colombia, Costa Rica, } \\
\text { Dominican Republic, } \\
\text { Perú, Puerto Rico, and } \\
\text { Venezuela }\end{array}$ & 20-85 & $\begin{array}{l}\text { FPG } \geq 126 \mathrm{mg} / \mathrm{dL} \text { or } \\
\text { self-reported current } \\
\text { pharmacological treatment }\end{array}$ & $\begin{array}{l}\text { Average prevalence of } 5 \%, 4.8 \% \text { in } \\
\text { women and } 5.1 \% \text { in men } \\
\text { Puerto Rico had a significantly higher } \\
\text { prevalence of DM }\end{array}$ \\
\hline $\begin{array}{l}\text { Brazilian Longitudinal Study of } \\
\text { Adult Health (ELSA-Brasil) (135) }\end{array}$ & 2008-2010 & 15,105 & $35-74$ & $\begin{array}{l}\text { Self-reported diagnosis, } \\
\text { medication use, } \\
\text { FPG } \geq 126 \mathrm{mg} / \mathrm{dL}, 2-\mathrm{h} \\
\text { post-OGTT } \geq 200 \mathrm{mg} / \mathrm{dL} \text {, or } \\
\mathrm{HbA} 1 \mathrm{c} \geq 6.5 \%\end{array}$ & $\begin{array}{l}\text { Prevalence of DM was } 19.7 \% \\
\text { Proportion of previously diagnosed DM } \\
\text { was } 50.4 \%\end{array}$ \\
\hline $\begin{array}{l}\text { CESCAS [Centro de Excelencia en } \\
\text { Salud Cardiovascular para el Cono } \\
\text { Sur] I Study (136) }\end{array}$ & 2010-2011 & $\begin{array}{l}7,524 \\
\text { Argentina, Chile, and } \\
\text { Uruguay }\end{array}$ & $35-74$ & $\begin{array}{l}\mathrm{FPG} \geq 126 \mathrm{mg} / \mathrm{dL} \text { or self- } \\
\text { reported history of diabetes }\end{array}$ & $\begin{array}{l}\text { Prevalence of DM of } 12.4 \%, 10.6 \% \text { in } \\
\text { men, and } 14 \% \text { in women }\end{array}$ \\
\hline $\begin{array}{l}\text { Panama Survey of Life and Health } \\
\text { Quality (ENSCAVI) and Survey } \\
\text { of Risk Factors Associated } \\
\text { with Cardiovascular Diseases } \\
\text { (PREFREC) (137) }\end{array}$ & $\begin{array}{c}2007 \\
2010-2011\end{array}$ & $\begin{array}{l}25,748 \\
3,590\end{array}$ & $\begin{array}{l}\geq 18 \\
\geq 18\end{array}$ & $\begin{array}{l}\text { Self-reported diagnosis of } \\
\text { diabetes } \\
\text { FPG } \geq 126 \mathrm{mg} / \mathrm{dL} \text { and } \\
\mathrm{HbA} 1 \mathrm{c} \geq 6.5 \%\end{array}$ & $\begin{array}{l}\text { Prevalence of DM of } 5.4 \% \\
\text { Prevalence of previously diagnosed DM of } \\
7.3 \% \text { and combined prevalence of DM of } \\
9.5 \% \text { based on FPG and } \mathrm{HbA} 1 \mathrm{c}\end{array}$ \\
\hline $\begin{array}{l}\text { Multiethnic Study of Pre-Diabetes } \\
\text { and Diabetes in LMIC (138) }\end{array}$ & 2010-2011 & $\begin{array}{l}23,496 \\
\text { Southern Cone of Latin } \\
\text { America, Peru, South } \\
\text { Asia, and South Africa. }\end{array}$ & $\geq 20$ & $\begin{array}{l}\text { Diabetes: FPG } \geq 126 \mathrm{mg} / \mathrm{dL} \\
\text { Prediabetes: } 100-125 \mathrm{mg} / \mathrm{dL}\end{array}$ & $\begin{array}{l}\text { Prevalence of DM and prediabetes } \\
\text { was } 14.0 \text { and } 17.8 \% \text {, respectively, in } \\
\text { the Southern Cone of Latin America; } \\
\text { estimates were } 9.8 \text { and } 17.1 \% \text {, } \\
\text { respectively, in Perú. }\end{array}$ \\
\hline $\begin{array}{l}\text { CRONICAS } \\
\text { Centro de Excelencia de } \\
\text { Enfermedades Crónicas Cohort } \\
\text { Study (139) }\end{array}$ & 2010-2013 & $\begin{array}{l}3,135 \\
\text { Four Peruvian sites }\end{array}$ & $\geq 35$ & $\begin{array}{l}\text { FPG } \geq 126 \mathrm{mg} / \mathrm{dL} \text { or } \\
\text { self-reported current } \\
\text { pharmacological treatment }\end{array}$ & Overall prevalence of $7.1 \%$ \\
\hline
\end{tabular}

FBG, fasting blood glucose.

TABLE 7 | Incidence of type 2 diabetes and gestational diabetes mellitus among Hispanic/Latino populations in Latin America.

\begin{tabular}{|c|c|c|c|c|c|}
\hline Study and reference & $\begin{array}{l}\text { Study } \\
\text { period }\end{array}$ & Sample size & $\begin{array}{l}\text { Age range } \\
\text { (years) }\end{array}$ & Glycemic criteria & Key findings \\
\hline $\begin{array}{l}\text { Brazilian Gestational } \\
\text { Diabetes Study (142) }\end{array}$ & $1991-1995$ & 4,977 & $\geq 20$ years & $\begin{array}{l}\text { OGTT } \\
\text { ADA } 2000 \\
\text { WHO } 1999\end{array}$ & $2.4 \%$ presented with GDM by ADA criteria and $7.2 \%$ by WHO criteria. \\
\hline $\begin{array}{l}\text { Mexico City Diabetes } \\
\text { Study (143) }\end{array}$ & $1990-2008$ & 1,939 & $35-64$ & $\begin{array}{l}\text { OGTT } \\
\text { ADA criteria }\end{array}$ & $\begin{array}{l}\text { Cumulative incidence was } 14.4 / 1,000 \text { and } 13.7 / 1,000 \text { for men and } \\
\text { women, respectively. } \\
\text { Incidence was 15.8/1,000,15.7/1,000, and 12.7/1,000 for the second } \\
\text { (1994), third (1998), and fourth (2008) follow-up phases, respectively. }\end{array}$ \\
\hline $\begin{array}{l}\text { CRONICAS Cohort } \\
\text { Study (139) }\end{array}$ & $2010-2013$ & $\begin{array}{l}3,135 \\
\text { Four Peruvian } \\
\text { sites }\end{array}$ & $\geq 35$ & $\begin{array}{l}\mathrm{FPG} \geq 126 \mathrm{mg} / \mathrm{dL} \text { or } \\
\text { self-reported current } \\
\text { pharmacological } \\
\text { treatment }\end{array}$ & $\begin{array}{l}\text { Overall incidence of } 1.95 \text { per } 100 \text { person-years. } \\
1.97 \text { per } 100 \text { person-years in women and } 1.93 \text { per } 100 \text { person-years } \\
\text { in men. }\end{array}$ \\
\hline
\end{tabular}

1,000 person-years for the follow-up studies conducted in 1994, 1998, and 2008, respectively. These figures suggest that this population has one of the highest diabetes incidence rates worldwide, and that incidence rates have remained fairly stable.

\section{Other CV Risk Factors in Hispanics/ Latinos Overweight/Obesity}

In the most recent NHANES examination (2013-2014 cycle), the age-adjusted prevalence of obesity in adults ( $>20$ years) was $37.1 \%$ for NHWs and $42.7 \%$ for Hispanics/Latinos, with Hispanic/Latino men and women having $21 \%$ and $33 \%$ increased odds of obesity compared to NHWs, respectively (144). In the most current NHANES examination, the prevalence of obesity in children was $14.7 \%$ for NHWs and $21.9 \%$ in Hispanics/Latinos, and extreme obesity was $4.4 \%$ in NHWs and $7.6 \%$ in Hispanics/ Latinos (145). In the baseline examination (2008-2011) of the HCHS/SOL, $77 \%$ of participants had overweight or obesity, and the age-adjusted prevalence of obesity ranged from $26.8 \%$ in South American men to $51.4 \%$ in Puerto Rican women (84). 
However, enlarged waist circumference $(\geq 102 \mathrm{~cm}$ in men and $\geq 88 \mathrm{~cm}$ in women) was highly prevalent among men (73\%) and women (96\%), independent of the heritage group (146). A higher prevalence of overall obesity in women compared to men, and high prevalence of abdominal obesity have also been described in Puerto Rico $(147,148)$.

The CARMELA study reported an overall obesity prevalence of $23 \%$, ranging from $16 \%$ in Quito, Ecuador to $31 \%$ in Mexico City, Mexico (128). The LASO reported that overall obesity ranged from $13.8 \%$ in men to $18.4 \%$ in women, and that abdominal obesity ranged from $15.4 \%$ in men to $55.5 \%$ in women (133). CESCAS I reported a prevalence of $35.7 \%$ obesity and $52.9 \%$ central obesity (136), whereas CRONICAS reported a prevalence of $44.0 \%$ overweight and $26.0 \%$ obesity among individuals without diabetes, and $40.8 \%$ overweight and $39.9 \%$ obesity among those with diabetes; and enlarged waist circumference in $71.5 \%$ without diabetes and $88.5 \%$ with diabetes (139); and in ELSA-Brasil, 40.2 and $22.9 \%$ had overweight and obesity, respectively (149). Although the prevalence of obesity in some regions of Latin America has been lower than that of Hispanics/Latinos in the US, in others it is comparable.

A systematic review of studies published between 2008 and 2013 estimated that the prevalence of overweight and obesity for children and adolescents throughout Latin America ranged from 18.9 to $36.9 \%$ in children aged $5-11$ and 16.6 to $35.8 \%$ in adolescents aged 12-19 (150). An obesity trend analysis from Mexico (2012) revealed a significant increase during the same time frame in which obesity increased in the US $(145,151)$. The prevalence of overweight/obesity also increased in Colombia from $38.2 \%$ in 2000 to $43.1 \%$ in 2010 (152).

\section{Hypertension}

In the 2009-2010 NHANES cycle, the age-adjusted prevalence of hypertension among US adults was $29.8 \%$ for NHW men, $26.9 \%$ for NHW women, 26.3\% for Mexican American men, and 27.7\% for Mexican American women (153). In the HCHS/SOL, the ageadjusted prevalence of hypertension was $25.5 \%$ (154).

In CARMELA, hypertension prevalence ranged from $7.2 \%$ (men) and $10.1 \%$ (women) in Ecuador to $37.7 \%$ (men) and $21.7 \%$ (women) in Argentina (155). LASO reported a mean prevalence of $20.2 \%$ (133). CRONICAS reported a prevalence of $23.9 \%$ for individuals without diabetes, and $50.9 \%$ for individuals with diabetes (139). ELSA-Brasil reported a mean prevalence of $25.7 \%$ in women and $34.5 \%$ in men (149). In CESCAS I hypertension prevalence ranged from $36.9 \%$ in Temuco, Chile to $45.3 \%$ in Bariloche, Argentina, and a mean of $40.8 \%$ in Chile, Argentina, and Uruguay (136).

\section{Dyslipidemia}

In the 2011-2012 NHANES cycle, prevalence of high total cholesterol was $13.5 \%$ in NHWs and $14.2 \%$ in Hispanics/Latinos, and the prevalence of low high-density lipoprotein cholesterol (HDL-C) was $17.1 \%$ in NHWs and $21.8 \%$ in Hispanics/Latinos (156). In the HCHS/SOL, the prevalence of elevated total cholesterol was $13.9 \%$ in women and $14.3 \%$ in men, elevated low-density lipoprotein cholesterol (LDL-C) was $34 \%$ in women and $38.2 \%$ in men, triglycerides (TGs) $>200 \mathrm{mg} / \mathrm{dL}$ was $10.2 \%$ in women and $19.8 \%$ in men, and low HDL-C was $47.9 \%$ in women and $34.3 \%$ in men (157).

In CARMELA, the prevalence of hypercholesterolemia ranged from 5.7\% in Barquisimeto, Venezuela to 20.2\% in Quito, Ecuador (128). CESCAS I reported an overall prevalence of hypercholesterolemia of $24.4 \%$ (which ranged from $20.8 \%$ in Bariloche, Argentina to $31.0 \%$ in Barros Blancos, Uruguay), high LDL-C of $23.1 \%$, low HDL-C of $34.1 \%$, and hypertriglyceridemia of $22.1 \%$ (136). LASO reported an overall prevalence of $8.9 \%$ of elevated total cholesterol, $8.5 \%$ of high LDL-C, $53.3 \%$ of low HDL-C, and $26.5 \%$ of high TGs (133). ELSA-Brasil reported a mean prevalence of hypercholesterolemia of $68.2 \%$ in women and $65.5 \%$ in men (149). Although the prevalence of lipid and lipoprotein abnormalities varies by region and study, it seems like low HDL-C is highly prevalent across Hispanic/Latino populations in the US and Latin America.

\section{Tobacco Use}

The prevalence of smoking among US adults is $16.7 \%$ for men and $13.6 \%$ for women, with distinct racial/ethnic differences (158). The prevalence among NHWs is $20.2 \%$, and $10.1 \%$ for Hispanics/ Latinos, nationwide. However, the HCHS/SOL demonstrated a higher overall prevalence of daily smoking (16.9\% in men and $10.7 \%$ in women) and significant differences among heritage groups with higher prevalence of daily smokers in Puerto Rican men $(27.0 \%)$, Cuban men $(26.2 \%)$ and Puerto Rican women $(24.2 \%)$, and lower smoking prevalence in Dominican men (8.8\%) and Mexican women (4.4\%) (159).

In Latin America, the CARMELA reported a prevalence of current smoking that ranged from $21.8 \%$ in Barquisimeto, Venezuela to $45.4 \%$ Santiago, Chile (128). LASO reported a mean prevalence of $25.8 \%$ (133), and CESCAS I reported a mean prevalence of $29.7 \%$ in Argentina, Chile, and Uruguay (136). ELSA-Brasil reported a mean prevalence of current smoking of $15.5 \%$ in women and $16.7 \%$ in men (149). In contrast, CRONICAS reported a prevalence of daily smoking of $3.3 \%$ among individuals without diabetes, and $2.7 \%$ among those with diabetes in Perú (139).

\section{Behavioral Risk Factors}

Cardiometabolic factors are influenced by modifiable behavioral risk factors, namely physical activity (PA), and dietary intake. The 2010 Racial and Ethnic Approaches to Community Health Risk Factor Survey estimated approximately one-third of Hispanic/Latino men and women met PA recommendations (160). Moreover, using objective measures, the HCHS/SOL reported that Hispanic/Latino adults spent $11.9 \mathrm{~h} /$ day, or $74 \%$ of their monitored time, in sedentary behaviors, with less time for Mexicans and more for Dominicans (161). CESCAS I reported a prevalence of physical inactivity of $35.2 \%$ (136); ELSA-Brasil reported a mean prevalence of physical inactivity of $79.8 \%$ in women and $70.9 \%$ in men (149).

In the HCHS/SOL, differences in total energy, macronutrient, and nutrient-dense intakes were observed among the different heritage groups (162), with higher total energy and macronutrient intakes by Cubans, higher fiber intake by Mexicans, lower 
fiber intake by Puerto Ricans and lowest total energy intake by Dominicans. Evaluations of the dietary intake and quality based on the 2010 Alternate Health Eating Index and the Dietary Approaches to Stop Hypertension (DASH) revealed overall low scores for intakes of whole grains, and fruit and vegetables with lower dietary quality for Puerto Ricans and higher quality for Mexicans $(163,164)$.

Dietary patterns in Latin America have been gradually shifting toward increased consumption of sugars and meat, and decreased consumption of fruit and cereals across the continent (165, 166). In CESCAS I, 85.5\% of participants reported low intake of fruits and vegetables (136). CRONICAS reported that $3.8 \%$ of individuals without diabetes and $9.5 \%$ with diabetes consumed 5 or more servings of fruits/vegetables per day (139). ELSA-Brasil reported low health dietary scores (1.23-1.38 out of 5) (149).

\section{ETIOLOGY OF TYPE 2 DM IN HISPANICS/ LATINOS}

Multiple factors contribute to type $2 \mathrm{DM}$ risk including: genetic variations, demographic characteristics, and behavior- and lifestyle-related risk factors (167). Among the pathophysiologic defects in type $2 \mathrm{DM}$, insulin resistance along with $\beta$-cell failure are considered major defects (168). Alterations in the adipose tissue (endocrine organ), the gut incretin-system (enteroinsular axis), renal reabsorption of glucose, and brain insulin response also play important roles in the development of glucose intolerance and type $2 \mathrm{DM}$ (169). In addition, alterations in the crosstalk between immune and metabolic pathways are closely linked to obesity and diabetes (170). Inflammation is also recognized as a common pathway for the major complications of atherosclerosis, stroke, and ischemic heart disease, commonly observed in persons with diabetes (171). Some of these aspects have been studied in Hispanics/Latinos.

\section{Obesity and Insulin Resistance}

As reported in other ethnic groups, type $2 \mathrm{DM}$ is associated with obesity in Hispanics/Latinos (172). However, obesity does not explain the excess diabetes prevalence among Hispanics/Latinos compared to NHWs (172). For instance, $29.3 \%$ of participants of HCHS/SOL with prediabetes had normal weight (95). On the other hand, duration of obesity or earlier age of onset has been associated with increased risk of developing type 2 DM (173-175).

In addition to overweight or obesity, the distribution of the adipose tissue has been associated with increased risk for type 2 DM and CVD. Non-alcoholic hepatic steatosis, for example, has been described in some Hispanic/Latino groups, and has been linked to increased insulin resistance and other cardiometabolic abnormalities $(176,177)$.

Data from the SAHS showed that insulin resistance measured by several insulin resistance surrogates accounts for a significant proportion of the excess type $2 \mathrm{DM}$ risk in Mexican-Americans compared to NHWs (178). This study also showed evidence of higher all-cause and CV mortality among Hispanics/Latinos born in the US (179).

\section{Adipokines, Hypercoagulability, Inflammation, and Endothelial Dysfunction Biomarkers}

Several adipokines and inflammation and hypercoagulability mediators, such as leptin, intercellular adhesion molecule-1, tissue plasminogen activator, inhibitor of plasminogen activator-1, high-sensitivity C-reactive protein (CRP), macrophage chemoattractant protein 1 (MCP-1), tumor necrosis factor (TNF)- $\alpha$, and interleukin-6 (IL-6) have been found to be elevated in young Hispanics/Latinos at high risk of developing type 2 DM (180-189) and individuals from different racial/ethnic groups-including Hispanics/Latinos-with type 2 DM (189-194). Elevated IL-6, leptin, CRP, and TNF- $\alpha$ have been observed in Mexican Americans with type 2 DM, and the elevation IL-6 and leptin in particular was linearly associated with increasing glycemia (194).

For example, in a prospective study of Hispanic/Latino adolescents with obesity, higher baseline MCP-1 or IL- 6 levels at prepubertal age were associated with a 16 and $21 \%$ greater decline in insulin sensitivity during puberty (195). However, this relationship between proinflammatory/endothelial dysfunction markers and insulin sensitivity has been shown to vary with adipose tissue distribution, and may differ across racial/ethnic groups $(188,192)$. Adiponectin, a collagen-like protein secreted from adipose tissue has been inversely correlated with both insulin sensitivity and adiposity (196-198), and increased risk of developing type $2 \mathrm{DM}$ in Hispanic/Latino adults (199). Adiponectin inversely correlates with CV risk factors in older adults (200), and appears to predict progression to glycemic failure in adolescents with type 2 DM from different ethnic groups $(200,201)$. A cautionary note: Most of these studies have been small, and the representation of Hispanic/Latino heritage groups has been very limited.

\section{Other Factors}

Maternal factors such as fasting indexes of total triiodothyronine, insulin, leptin, and ghrelin have been associated with excessive weight gain in Hispanic/Latino children (202-204). Women who experience GDM are at high risk of developing GDM in subsequent pregnancies $(205,206)$ and type 2 DM (205). In addition, children born to women with GDM are at increased risk of obesity and glycometabolic disease later in life (204-214). Increased proinflammatory markers have also been identified in women with GDM (215). Research studies involving Hispanic/Latino women in the US or in Latin America have described increased proinflammatory markers (e.g., proinflammatory cytokines and/or natural killer cells) at the placental level (216-218), and at both the placental and fetal level (219) associated with maternal hyperglycemia during pregnancy. In Mexican women, prepregnancy overweight and obesity have been associated with increased oxidative stress in the newborn (220). In Chile, in women with overweight or obesity and GDM, maternal elevated TGs were associated with increased infant's birth weight (BW), despite good maternal glucose control (221). Maternal hyperglycemia, whether due to preexisting diabetes or GDM, has been associated with increased oxidative stress and maternal DNA damage $(222,223)$, and both placental and umbilical cord DNA damage $(222,223)$. However, the number 
of patients in these studies has been small, and the interaction of obesity or other proinflammatory factors cannot be separated from hyperglycemia. Whether these changes could be prevented or reversed is unknown.

Low BW, like maternal GDM, has been inversely associated with glucose intolerance and insulin sensitivity during childhood and increased risk for CVD later in life. This susceptibility to adult chronic diseases may be a response to exposures in utero-known as fetal programming-or early malnutrition in extra uterine life $(224,225)$. Several studies in Latin America have documented the inverse association between BW and insulin sensitivity later in life (226), malnutrition during the first year of life and insulin sensitivity, glucose tolerance and metabolic syndrome later in life (227-229); and being exclusively or predominantly breastfed $>12$ months and lower adiposity and serum cholesterol during childhood (230).

Chronic malnutrition is associated with alterations in glucose metabolism and insulin sensitivity (231). Decades ago, a malnutrition-modulated diabetes or tropical diabetes was described in developing countries $(232,233)$. Some investigators hypothesized that consumption of cassava (manioc or tapioca) could lead to diabetes in malnourished subjects, due to cyanogenic glycosides leading to chronic pancreatitis; however, the theories remained largely speculative (232). Others postulated that chronic protein energy malnutrition would cause persistent insulin deficiency and glucose intolerance without ketosis, among other clinical features (234-236).

A link between plasma branched-chain amino acids (BCAAs) and insulin clearance has been observed in recent years. Overweight persons exposed to a diet high in saturated fat have been found to have a significant inverse correlation between plasma BCAAs and insulin clearance. This association has also been observed in Hispanics/Latinos (237).

Atypical forms of diabetes such as ketosis prone diabetes (KPD) have also been described in Hispanics/Latinos. KPD affects $20-50 \%$ of African-American and Hispanic/Latino patients with new diagnoses of diabetic ketoacidosis (238). Hispanics/Latinos with KPD also appear to be disproportionally affected by KPD characterized by an absence of autoantibodies and presence of $\beta$-cell functional reserve $(239,240)$.

Sleep disruptions characteristic of obstructive sleep apnea (OSA) and that alter sleep duration and timing may promote behavioral, metabolic, and/or hormonal changes associated with changes in weight (241-244). OSA is independently associated with insulin resistance (245) and predicts subsequent risk for type $2 \mathrm{DM}$ (246). In the HCHS/SOL, both quantity and quality of sleep were associated with higher odds of having type $2 \mathrm{DM}(247,248)$ and impaired glucose tolerance (IGT) (247) with the greatest odds among those with short sleep duration and insomnia (249). Three loci have been found to be significantly associated with OSA traits in a large genome-wide association study of 12,558 Hispanics/ Latinos (250). The association of fasting blood glucose and OSA was weaker among Hispanics/Latinos in MESA compared to African Americans (AA) and NHWs (251).

In recent years, Alzheimer's disease $(\mathrm{AD})$ has been considered as a metabolic disease mediated by alterations in brain insulin responsiveness, glucose utilization, and energy metabolism that can lead to increased oxidative stress, inflammation, and worsening insulin resistance (252). The association between type $2 \mathrm{DM}$ and $\mathrm{AD}$ has been called type 3 diabetes (253). Mexican American elders with diabetes are at almost twofold increased risk of dementia than those without diabetes (254). Also, longer duration of diabetes has been associated with a faster rate of cognitive decline in this age group (255). Further research is needed to examine the interaction of type $2 \mathrm{DM}$ and $\mathrm{AD}$ in this vulnerable group, and among other Hispanic/Latino groups.

Other emerging risk factors for type $2 \mathrm{DM}$ and CVD include the gut microbiome (256-258), gallbladder disease (259), environmental exposures (260-262), and the impact of sugarsweetened beverages intake on satiety (263). Research on these emerging factors in Hispanics/Latinos has been limited.

\section{Genetics and Type 2 DM in Hispanics/ Latinos}

The polygenic nature of type $2 \mathrm{DM}$ is well established and more than 100 loci for type $2 \mathrm{DM}$ and glycemic traits have been identified through genome-wide association studies (GWAS) of common and rare variation in populations of diverse ancestral origins (264).

Genetic variations in the gene encoding for transcription factor 7-like 2 (TCF7L2) have been associated with type 2 DM in different populations (265). The T allele of single nucleotide polymorphism (SNP) rs7903146 of TCF7L2 strongly predicts the development of type 2 DM $(265,266)$. TCF7L2 has been associated with GDM and type 2 DM in Hispanics/Latinos of Mexican descent $(267,268)$, and polymorphisms of this gene have been associated with reduced acute insulin response in this heritage group (269). This gene has also been associated with diabetes in the HCHS/SOL (270). TCF7L2 polymorphism rs7903146 has also been associated with coronary artery disease $(271,272)$ and stroke (273) among patients with long standing history of type 2 DM.

A haplotype containing four missense SNPs, all in SLC16A11, conferring 20\% increased risk for type 2 DM was identified through GWAS in Mexican and other Latin American samples in the SIGMA type 2 DM Consortium (274). A newly identified African ancestry-specific allele at KCNQ1 was associated diabetes in HCHS/SOL (270), however, the mechanisms leading to type $2 \mathrm{DM}$ due to alterations in this allele are less well understood (275).

Whole-exome sequencing in 3756 individuals of Mexican and Mexican American ancestry identified a rare variant (p.E508K) in HNF1A that had significant association (fivefold increase) with type 2 DM (276). HNF1A is the gene responsible for MODY3, a monogenic, early-onset form of type $2 \mathrm{DM}$, however carriers of p.E508K did not show early-onset of type $2 \mathrm{DM}$ and were indistinguishable from the wider type $2 \mathrm{DM}$ population, thus not fulfilling the classical diagnostic criteria for MODY3 (276).

The Genetics Underlying Diabetes in Hispanics/Latinos (GUARDIAN) Consortium (277) conducted a GWAS in multiple Mexican-ancestry cohorts with highly detailed glucose homeostasis measures. Nonparametric meta-analysis of the Discovery and Translation cohorts identified a significant relationship with 
type 2 DM phenotype at 6p24 (SLC35B3/TFAP2A) in association with glucose effectiveness, 11p15 (KCNQ1) with disposition index, and 6p22 (CDKAL1) and 11q14 (MTNR1B) with acute insulin response (277).

Genetic studies of GDM in Latin American women have yielded varied findings. In Brazilian women, GDM has been associated with the glucokinase gene (278), the MTNR1B gene polymorphism rs10830963 (279), LGALSI polymorphism (280) and IRS-1 (281). In Mexican women, GDM has been associated with polymorphisms of the HNF4A gene (282), the TNF- $\alpha$ gene promoter (283), the MTNR1B gene (284), the CENTD2 gene (284), the KCNQ1 haplotype (284), and the TCF7L2 gene $(284,285)$. However, polymorphisms of the fat mass and obesityassociated (FTO) and the TCF7L2 genes have not been associated with GDM in Brazilian women (286), and SLC16A11 locus was not associated with GDM in Mexican women (284).

Among Mexican American subjects recruited in the San Antonio Family Heart Study, DNA methylation levels at five CpG sites, mapping to three well-characterized genes (TXNIP, ABCG1, and SAMD12) independently explained $7.8 \%$ of the heritability of type $2 \mathrm{DM}$ (287). In the same population, individuals with the hypertriglyceridemic waist phenotype [waist circumference $\geq 95 \mathrm{~cm}$ in men and $\geq 80 \mathrm{~cm}$ in women] combined with high serum TG concentration $(\geq 2.0 \mathrm{mmol} / \mathrm{L}$ in men and $\geq 1.5 \mathrm{mmol} / \mathrm{L}$ in women) were found to have epigenetic changes (DNA methylation) in genes involved in $\beta$ oxidation of long-chain fatty acids (CPT1A) and triglyceride storage (ABCG1) (288).

In summary, these findings have shown the broad complexity of the pathophysiology of metabolic disease and research focused on Hispanics/Latinos. Broader attention to different heritages should be considered in future studies to better stratify subjects at risk for type $2 \mathrm{DM}$ and develop intervention strategies according to different genotypic and phenotypic traits.

\section{INTERVENTIONS TO PREVENT TYPE 2 DM AMONG HISPANICS/LATINOS}

\section{Lifestyle Interventions to Prevent Type 2 DM in Hispanic/Latino Women with History of GDM}

The increasing prevalence of obesity and metabolic disease in young Hispanics/Latinos (and other racial/ethnic groups) has raised thought-provoking questions about the role of maternal health and the intrauterine environment on the child's future risk for type $2 \mathrm{DM}$ and obesity. As previously described, women who experience GDM are at high risk of developing GDM in subsequent pregnancies and type $2 \mathrm{DM}$, and their children are at increased risk of metabolic disease.

The quality of dietary fat intake (289) and PA (290-293) during mid-pregnancy have been as proposed factors that could influence the risk of GDM in Latin American women. However, clinical studies evaluating the effect of exercise training on pregnancy outcomes have yielded inconsistent or even conflictive results $(292,294)$. In a systematic review by Perales et al., the authors concluded that the combination of aerobic and resistance training during pregnancy seemed to produce the most favorable effect on different maternal health parameters, but that this combination (or either type of exercise separately) yielded an overall weak effect on reducing GDM (294). Previous history of GDM, preexisting overweight or obesity, gestational weight gain, intensity, frequency, duration, and timing of exercise, and adherence to the PA regime may be factors impacting program efficacy $(292,294)$.

Research focused on preventing GDM or type $2 \mathrm{DM}$ in women with a history of GDM-especially Hispanics/Latinas-has been scarce. Some studies have evaluated PA and weight gain/ retention during pregnancy or postpartum (295-297). In the Behaviors Affecting Baby and You Study $(n=110$ women at risk of GDM, $60 \%$ Hispanic/Latina) participants were randomized to either a 12-week tailored PA intervention or usual wellness care (295). Women on the tailored exercise intervention had smaller decrease in postpartum PA than the control group (-1.0 METhours/week versus -10.0 MET-hours/week). In the Diet Exercise and Breastfeeding Intervention Study $(n=116,35.5 \%$ Hispanic/ Latina), pregnant women with GDM were randomized to either a Diabetes Prevention Program (DPP)-modeled intervention that started during pregnancy and continued postpartum, or usual care to determine feasibility and changes in metabolic parameters (296). In a subsample of 72 participants, women who had lost $>2 \mathrm{~kg}$ experienced lower increases in fasting glucose, $2 \mathrm{~h}$-glucose and homeostasis model assessment of insulin resistance (HOMA-IR) at 12 months postpartum. Hispanic/Latino women were more likely to maintain or gain weight postpartum than women from other racial/ethnic groups (296).

In the Gestational Diabetes' Effects on Moms Study ( $n=2,280$ women with GDM, 22.2\% Hispanic/Latina), a DPP-modeled intervention between 6 weeks and 6 months postpartum was compared to a usual care (mailed recommendations only) (297). The intervention arm had $28 \%$ higher odds of meeting postpartum weight goals than usual care. A greater proportion of women on the intervention arm had less weight retention at 6 weeks ( $25.5 \mathrm{vs.}$ $22.4 \%$ ) and 6 months postpartum (30.6 vs. 23.9\%, mean weight lost $=1.89$ vs. $0.94 \mathrm{~kg}$ ) compared to the women in usual care. However, the difference was no longer significant at 12 months ( 33.0 vs. $28.0 \%$, mean weight lost $=1.19$ vs. $0.50 \mathrm{~kg}$ ). Also, at 6 months postpartum, the intervention arm had a greater increase in vigorous-intensity PA (mean $15.4 \mathrm{~min} /$ week) than usual care.

In the Parish Nurse Intervention Program (298), 100 Mexican American women with GDM were randomized to an interviewbased intervention assessing health-promoting behaviors and lifestyle or to usual care. At postpartum, intervention participants reported higher scores on health-promoting behaviors than women receiving usual care. While promising, there were no significant differences in blood glucose, HbAlc, macrosomia, and other biometric parameters. In the Dulce Mothers Project, 84 Hispanic/Latino women with previous GDM were randomized to a shortened 8-week DPP-modeled intervention, or usual care (299). After 6 months, intervention participants reported a significantly higher $\mathrm{PA}$ and lower fat intake, but there were no changes in body weight or BMI. Although changes in HbA1c\% (5.73-5.82\%), total cholesterol (180-169.9 mg/dL), LDL-C (107.8-100.4 mg/dL), and TGs (124-110.3 mg/dL) were statistically significant, they were not clinically significant. In 
the Estudio Vida (300), 68 pregnant Hispanic/Latino women of unspecified ancestry were randomized to a 6-month culturally and linguistically modified lifestyle intervention (monthly in-person behavioral counseling, and five telephone-delivered booster sessions, plus follow-up 6 weeks postpartum) or to usual care, to compare PA, gestational weight gain, infant BW, and biomarkers of insulin resistance postpartum. Although the intervention was shown to be feasible, no changes were observed in any of the outcomes (300).

Some of the studies described above did not report the Hispanic/Latino heritage group of the participants and/or assess cardiometabolic markers. In addition, it is unknown whether the follow-up of participants continued beyond the intervention period, and whether the risk for future GDM or type $2 \mathrm{DM}$ was reduced. Other interventions focused on Hispanic/Latino women with history of or at risk of GDM and involving lifestyle intervention have been proposed $(301,302)$ have been proposed or initiated. However, results have not yet been published.

\section{Lifestyle Interventions to Prevent Type 2 DM in Hispanic/Latino Youth in the US and Latin America}

Little information is available of type 2 DM prevention efforts focusing on the youth (303). To date, no published investigations are available to address type $2 \mathrm{DM}$ prevention in Hispanic/Latino youth with prediabetes. Although programs designed to prevent childhood and youth obesity have been extensively reviewed, these seldom assess blood pressure, lipids and lipoproteins and other metabolic markers, or adiposity (304-311). The effectiveness trials for prevention of type $2 \mathrm{DM}$ among youth are further challenged by a lack of consensus on parameters for disease risk indicators (adiposity, CV risk markers, resting energy expenditure), especially during puberty, and its associated changes in body composition, insulin sensitivity and or insulin secretion (312-317).

\section{Weight Loss and Obesity Prevention Trials}

Weight loss interventions focusing on children with overweight or obese have resulted in improved metabolic outcomes such as insulin sensitivity, lipids and adiposity measures (318-324). Most of these trials involved medium to high-intensity interventions focusing on physical activity (PA) and dietary intake (309, 311, 325). Interventions delivered in schools with home involvement (PA-only interventions), or with home and community components (diet and PA interventions) have produced the strongest evidence of the metabolic benefits of weight loss and, consequently, childhood obesity prevention in the US and Latin America (310, 325, 326).

While promising, there are few weight gain prevention interventions specifically focusing on Hispanics/Latinos in the US and Latin America (304, 308, 327). Reviews of childhood obesity interventions in Latin America and the Caribbean report encouraging trends in childhood obesity prevention and treatment programs in schools (328), healthcare (329), and settings such as home, summer camps and family clinics (330). However, these studies were mostly carried out in Mexico and Brazil, only three were randomized clinical trials (RCTs), and most did not include appropriate pediatric measures for BMI or participants' ages (327). In the US, evaluations of community-based interventions targeting multiple predictors of childhood obesity are underway via the CDC-funded Childhood Obesity Research Demonstration Projects (CORD) (331-334). Two of the sites will focus specifically on Hispanic/Latino populations.

\section{Dietary Considerations}

Although there is no prescribed diet for diabetes prevention among youth, reductions of saturated fats and sugars and increases in fruits, vegetables, and fiber are expected to prevent overweight among children $(335,336)$ and therefore are also used in weight loss intervention trials. However, some argue that diets for type $2 \mathrm{DM}$ prevention among youth should instead focus on low-glycemic foods (337). Small trials that test the safety and efficacy of intense diet modifications suggest that low-glycemic food choices decrease waist circumference, BMI z-score, and insulin resistance-assessed through the HOMA-IR-compared to higher glycemic food choices (323, 325, 337-341). Some authors argue that these diets lead to greater decreases in adipose tissue compared to low-energy and low-fat diets $(338,342)$. In terms of metabolic effects of these diets specifically among Hispanics/ Latinos, evidence is still emerging (325).

\section{Physical Activity Considerations}

Intervention trials involving exercise only (without diet restrictions) among youth and adults have shown effects on metabolic outcomes and cardiorespiratory fitness without affecting weight or fat mass (343-349). Data specific to Hispanics/Latinos are limited, but in Mexico, Macías-Cervantes et al. observed a significant decrease in insulin and HOMA-IR after a randomized trial of a 12-week exercise training intervention in a RCT of 76 children, aged 6-9 years, with no significant changes in BMI or diet between control and intervention groups (347). Of note, the ADA recommends that children engage in 60 minutes of exercise per day most days, and that they limit time in front of a screen to less than 2 hours a day as a type $2 \mathrm{DM}$ prevention strategy in children (336).

\section{Preventing Prediabetes in School-Aged Children}

DPPs in school settings have been somewhat successful at increasing PA (and sometimes improving diet) via education and handson activities. However, their effects on BMI, adiposity measures, and lipids have been inconsistent (305, 350-353). Results are difficult to compare due to the range of both the cardiometabolic risk indicators assessed and the age of the children included in the studies.

Lifestyle intervention trials have been conducted in schools with large $(>50 \%)$ Hispanic/Latino populations to achieve change in metabolic and anthropometric outcomes among normal-weight students. These interventions have often involved PA and healthful nutrition education components and activities that are incorporated into the schools' curricula (regular and PA classes) and cafeteria. After 4-7 month interventions involving elementary- and middle-school children, several studies reported significant improvements in behavioral or metabolic outcomes, 
without an effect on anthropometrics (354-356). Two additional studies with similar school-based programs reported improvements in metabolic and anthropometric parameters in the US and Brazil (350,357), yet, not all studies have yielded significant results. For example, the HEALTHY study, a larger school RCT in seven centers in the US in which children in middle school (sixth to eighth grade, 54.2\% Hispanics/Latinos) were followed, did not observe significant decreases in overweight/obesity, lipid, hypertension, or other metabolic markers among Hispanics/ Latinos $(358,359)$.

Studies that focus on older Hispanic/Latino youth (aged 14-17 years) are less consistent in their findings. A small RCT in Brazil (360) reported that a high-intensity exercise intervention for 43 adolescents with obesity did not improve BMI, waist circumference, blood glucose, physical fitness, HDL-C, or lipids. Other studies in older Hispanic/Latino teenagers (14-17 years) with obesity in the US or Mexico used similar dietary intaketargeted interventions for an average 4-month period. Although they reported significant changes in some anthropometric measures, physical inactivity, diet, and cardiometabolic risk factors, they were insufficiently powered and did not include controls (361-363).

\section{Lifestyle Interventions to Prevent Type 2 DM in Hispanic/Latino Adults in the US and Latin America}

The evidence for successful type $2 \mathrm{DM}$ prevention interventions among adults is growing. However, the increasing prevalence and incidence of type $2 \mathrm{DM}$ among Hispanic/Latino adults suggest that preventive programs have not caught up with the needs of this population.

\section{The DPP}

The DPP is a seminal type 2 DM prevention trial (364). It recruited an ethnically diverse ( $N=3,234,16 \%$ Hispanics/ Latinos) cohort and established a multisite program that demonstrated that a lifestyle intervention targeting $7 \%$ body weight reduction and increase in PA (goal $=150$ minutes per week) effectively reduced by $58 \%$ (compared to placebo) the incidence of type $2 \mathrm{DM}$ among persons at high risk, and compared to $31 \%$ reduction with metformin $(364,365)$. The reduction of diabetes incidence was similar among race/ethnic groups, including Hispanics/Latinos (364). The percent of weight loss achieved by Hispanics/Latinos in the lifestyle intervention arm (women $7.3 \%$, men $7.7 \%$ ) was close to that of NHWs (women $7.9 \%$, men $8.5 \%)(366)$.

\section{Lifestyle Interventions Modeled after the DPP in Hispanics/Latinos in the US}

The success of the DPP has sparked numerous attempts to modify this individual-based intervention for delivery in various community settings serving culturally diverse groups (367-379). Many of these translations appear to be effective for weight loss and improvement in cardiometabolic parameters $(368,379)$, although questions remain as to appropriate dosage that makes interventions both accessible and cost-effective, as well as the way in which these interventions have been culturally adapted to different populations.

A recent review identified only five RCTs designed to evaluate lifestyle interventions aimed to reduce risk of type $2 \mathrm{DM}$ in Hispanics/Latinos (measured by reduction of weight or HbAlc) (380), and only two were deemed to have a strong quality rating. These two studies were conducted in women only (370) or mostly (>70\%) (368), and only one of them reported a significant reduction in HbA1c (368).

Most studies designed for type 2 DM prevention among Hispanics/Latinos culturally tailor their programs to the population of interest $(367-369,371,381)$. A recent review of culturally tailored type $2 \mathrm{DM}$ prevention interventions in US Hispanic/Latino adults described the varied approaches to cultural tailoring, which ranged from use of bilingual materials to community input on program content (380). As is the case in virtually all culturally adapted studies, none assessed the relative importance of various cultural adaptation elements, did not compare culturally adapted interventions and nonadapted approaches (380), and did not specify participants' ancestry or country of origin. While budgetary limitations often present barriers to these analyses, it would be important to ascertain the usefulness of elements of cultural adaptation, as well as to determine the variability of health-related behaviors by cultural origin $(84,163,382-384)$. There is a critical need for culturally adapted interventions to provide more detailed information on the methodology followed in the cultural adaptations, beyond the translation of materials, as well as to address the linguistic needs of many Latin American immigrants from indigenous communities, for whom Spanish is not a first language.

In Latin America, there seem to be no published studies modeled after the DPP, but several RCTs have evaluated the effect of lifestyle interventions on weight and metabolic outcomes among adults in Mexico and Brazil (384). The RCTs varied in size $(N=51-241)$, intervention dosage (weekly to monthly), duration (6-12 months), and specific intervention components. The dietary interventions included the DASH diet (385), low-glycemic diets (386), or diets recommending olive oil, fruits, and vegetables (387). The studies reported significant changes in body weight loss and/or metabolic markers, including fasting blood glucose, $\mathrm{HbAlc}$, and lipids (386-390).

\section{Pharmacological Interventions to Prevent Type 2 DM in Hispanic/Latino Adults in the US and Latin America}

A few pharmacological interventions focused on preventing or delaying type $2 \mathrm{DM}$ in Hispanics/Latinos have been published (391-395). The PPAR $\gamma$ agonists troglitazone (391) and pioglitazone (392) have demonstrated long-term preservation of $\beta$-cell function in Hispanic/Latino women with a history of GDM. Troglitazone significantly reduced the annual incidence rate of type $2 \mathrm{DM}$ (5.4 versus $12.1 \%$ for placebo) over a median 30-month follow-up (391), and pioglitazone demonstrated a significant decrease over 1-year period (392). 
Boyko et al. reported a significant and greater reduction in diabetes incidence (hazard ratio $=0.18$ over approximately 5 years, $P=0.0242$ ) in Latinos taking rosiglitazone, another PPAR $\gamma$ agonist, and South Asians showing the lowest reduction (393). De Fronzo et al. reported a similar effect of pioglitazone at reducing diabetes incidence (hazard ratio $=0.28$ over 2.4 years, $P<0.0001)$ among NHWs, AAs and Hispanics/Latinos compared to placebo (394).

O'Brien et al. (395) compared a 12-month intensive lifestyle intervention (DPP-modeled) led by promotoras to metformin, and to usual care in a group of 85 Hispanic/Latino women (aged $\geq 20$ years) with prediabetes (IFG and/or HbA1c 5.7-6.4\%). The investigators observed a significant reduction in weight $(-4.0 \mathrm{~kg}$ or $5.0 \%, P<0.001)$ as well as in BMI in women on the lifestyle intervention compared to the other groups. However, no significant changes in blood pressure, biochemical parameters, or HOMA-IR were observed. Of note, the mean adherence to metformin was $66.4 \%$.

\section{Pharmacological Interventions for Cardiometabolic Risk Factors in Hispanic/Latino Adults in the US and Latin America}

Pharmacological interventions specifically designed to improve cardiometabolic risk factors in Hispanics/Latinos at high risk of type $2 \mathrm{DM}$ are limited. Despite this limitation, we would like to highlight some key findings.

Four RCTs (396-400) designed to compare the effectiveness of combinations of angiotensin-converting enzyme (ACE) inhibitors or angiotensin II receptor blockers (ARBs) on blood pressure reduction and/or prevention of $\mathrm{CV}$ events with other antihypertensive medications reported that Hispanics/Latinos demonstrated good response to the therapies and maintenance of blood pressure control, similar or even superior than that observed in NHWs (396-399). In one of the trials, the addition of trandolapril to the treatment was associated with a lower incidence of diabetes and CV events among Hispanics/Latinos than in non-Hispanic participants (398). This observation is consistent with previous clinical trials (in which Hispanics/Latinos had not been included) that reported a lower incidence of type $2 \mathrm{DM}$ associated with ACE inhibitors and ARBs $(401,402)$. Also, a secondary data analysis on one of the trials revealed that a significantly larger percent $(75 \%)$ of Hispanic/Latino women $(n=5,017)$ reached blood pressure goals compared to $68 \%$ of NHW women $(n=4,710)$, and that Hispanic/Latino women experienced fewer CV events (5.7 versus $12.3 \%$ ) (403). In addition, Punzi et al. reported a significant reduction in blood pressure in Hispanics/Latinos with Stage I-II hypertension associated with nebivolol ( $\beta$ blocker) (404). Blood pressure control was achieved by $32-71 \%$ of participants depending on the dose. Some of these studies reported the Hispanic/ Latino heritage group of the participants or the Latin American countries where the studies were conducted. Other studies did not report nationalities or heritage group.

The results of the studies described above suggest Hispanics/ Latinos experienced similar or better response to antihypertensive therapy than patients from other demographic groups (405). In contrast, Yi et al. did not observe an increased blood pressure control with self-blood pressure monitoring in a low-income urban setting (406). Thus, the good response to hypertensive medications observed among Hispanics/Latinos in clinical trials may be both physiological and dependent on a controlled research setting. Future research may address underlying selfefficacy and contextual barriers that impeded the success of the self-monitoring and blood pressure control outside of clinical trials.

Various clinical trials evaluating the efficacy of lipid-lowering agents have reported significant reductions of total cholesterol and LDL-C, or CRP in US Hispanics/Latinos or Latin Americans (407-410), and comparable to reductions experienced by NHWs (407, 408). These studies have also reported good medication tolerance.

\section{Policies and Priorities and Diabetes Prevention Research in Latin America}

Countries throughout Latin America and the Caribbean are starting to raise awareness about chronic disease, including type 2 DM treatment and prevention. For example, the Latin American Association for Diabetes published guidelines about the treatment and management of type $2 \mathrm{DM}$ across medical associations in 17 countries (411). During the 2016 Pan American Health Organization (PAHO) symposium on Diabetes in the Americas, various countries described the epidemiology of diabetes in terms of incidence, prevalence, mortality, and risk factors. The review discussed policies or public awareness programs in place or designed to raise awareness of diabetes management focused mostly on nutrition education and physical activities (412).

Increased activities about prevention and treatment of type 2 DM, such as those described during the PAHO Diabetes in the Americas symposium, can be leveraged to increase our understanding of whether strategies designed to target type 2 DM risk factors (i.e., prediabetes, hypertension, and obesity) can actually lead to lower disease risk. As of May 2015, Chile and Mexico had implemented national-level taxes on sodas, and evaluations for these programs are underway (413). Various Latin American countries have set strategies, which have not yet been evaluated, to increase awareness about the harmful effects of transfatty acids (414) and of high salt intake (415-419). Other population-level initiatives include the creation of guidelines for healthful eating and PA; the creation of Ciclovía-Recreovía in Colombia (420), additional training of health care professionals to improve diabetes care, and diabetes screening initiatives in Chile, Argentina, and Honduras, nutrition labeling in Ecuador, and the ban of unhealthful foods in schools in Costa Rica, Perú and Guatemala (418). These new strategies present a unique opportunity to evaluate the process of implementation, the role of stakeholders in their design and implementation, and their eventual impact on anthropometric, lipids, and metabolic indicators or diabetes prevalence and treatment.

\section{PREVENTING TYPE 2 DM IN HISPANICS/ LATINOS-A HOLISTIC FRAMEWORK}

The epidemiology, etiology, and interventions studies selected for this review provide important insights on the magnitude 
of the prevalence, the complexity of potential mechanisms of disease, and the approaches toward preventing type $2 \mathrm{DM}$ in Hispanics/Latinos. Based on these insights, it is evident that the successful prevention of type $2 \mathrm{DM}$ in Hispanic/Latino populations in the US and Latin America would need a fundamentally radical transformation. In the era of personalized medicine, this transformation would require a holistic mission and a multidisciplinary approach.

This holistic framework integrates key domains that interact with each other (Figure 2). Within each domain we have identified areas that represent opportunities for enhancing the prevention of type $2 \mathrm{DM}$ in Hispanic/Latino populations-whether as a part of a research program or clinical care intervention. The Hispanic/Latino individual is at the center, and representing the most important element of the framework.

Our understanding of the burden of diabetes (type 1 and type 2) in Hispanic/Latino populations remains insufficient and should be prioritized. The development of effective type 2 DM preventive efforts requires continued surveillance of the burden of disease and its risk factors using disaggregated data on Hispanic/Latino subgroups. Adequate representation of diverse populations would enhance the identification of different phenotypes, and potential disease mediators and interactions. More detailed epidemiologic data at the country level in Latin America are urgently needed.
Consistency and standardization of methodology to assess the prevalence of diabetes in Hispanic/Latino populations would more accurately estimate its prevalence within and among countries and ethnic/heritage groups, and enhance comparison across studies. The need for consistency of methodology and for detailed disaggregated data could be addressed through the creation of repositories of deidentified data, and consortia (including representatives from research study groups, academic centers, medical societies, health authorities, and others) that would strategize the harmonization and/or standardization of methodology for data collection and analysis.

The identification of Hispanics/Latinos and Latin Americans in health-related research is inconsistent. Although the concept of a Hispanic/Latino monolith is slowly changing, the continued use of umbrella terms like "Hispanic" or "Latino" limits the ability of public health and clinical researchers to evaluate and address type $2 \mathrm{DM}$ risk factors that may impact or manifest differently across Hispanic/Latino heritage groups; and this in turns delays the development of effective preventive strategies.

The etiology of type $2 \mathrm{DM}$ is complex, and the research studies discussed in this review demonstrated areas in which further research could be developed. In this regard, it is not completely understood whether the oxidative stress, inflammatory and endothelial changes described in placental and umbilical cord tissue of pregnancies in which the mother had obesity or GDM could be prevented or reverted during pregnancy, and the impact

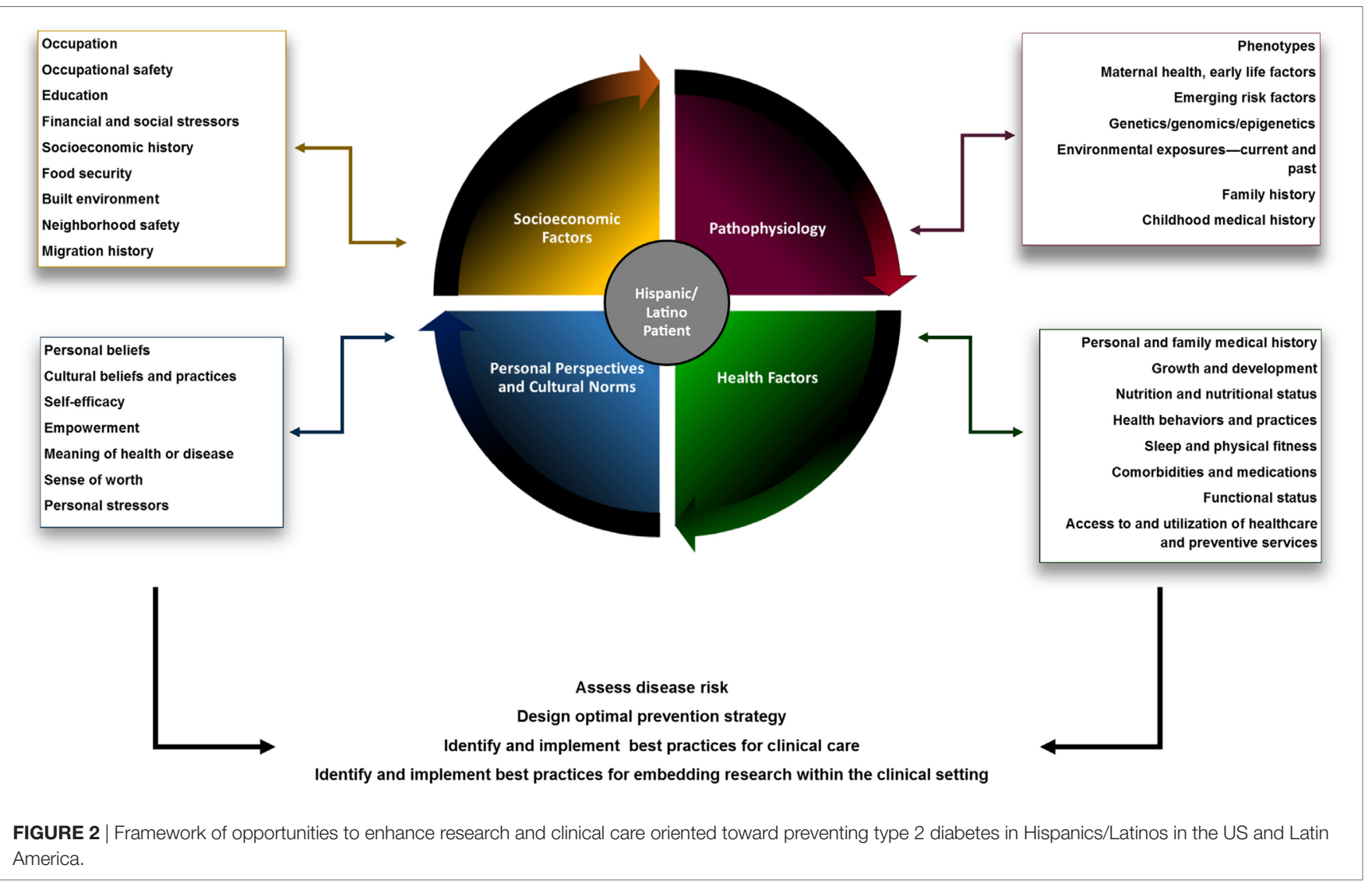


that such reduction would have on the child. At the same time, although GDM has been associated with increased risk for maternal type $2 \mathrm{DM}$, it is not clear whether GDM increases the mother's risk for CVD. Determining GDM risk (i.e., a predictive profile) for Hispanic/Latino women might identify those at risk early in pregnancy or before conception, so preventive interventions are tailored and initiated earlier.

Although obesity is associated with increased risk for type $2 \mathrm{DM}$, the distribution of adipose tissue (i.e., steatosis) has been associated to specific metabolic $(421,422)$ and cardiac structural abnormalities $(423,424)$. The study of other type 2 DM risk factors previously mentioned (e.g., sleep-disordered breathing, gut microbiome, environmental exposures) could uncover new mechanisms of disease, which can be turned into additional opportunities for interventions in Hispanic/Latino populations.

As the field of genetics/epigenetics/genomics continues evolving, additional insights on the gene-environment interaction (e.g., chronic stress, environmental endocrine disruptors, other environmental exposures) and the differences in susceptibility to type $2 \mathrm{DM}$ experienced by different Hispanic/Latino heritage groups in the US and Latin America might be uncovered. Thus, the inclusion of Hispanics/Latinos in these research studies needs to improve.

The clinical assessment of Hispanics/Latinos at risk of developing type $2 \mathrm{DM}$ needs to be comprehensive. The medical history needs to account underlying medical, nutritional, physical fitness, emotional, behavioral, cultural, and social factors. A detailed family history will uncover heredity patterns that could be relevant in the decision-making regarding therapy or genetic testing. The individuals' family dynamics and social network may also uncover dietary habits and values (425-427) that could impact the disease risk, the need for pharmacological therapy, and the effectiveness of the intervention. Socioeconomic factors will influence both type 2 DM risk and the success of any prevention strategy (368-371, 427-431). Access, availability and quality of food; social and family responsibilities, social network and support; stressors; of the built environment, neighborhood safety, transportation, and access to recreational activities; availability and access to health services, health insurance type, and coverage; access to and utilization of medications and medical services; formal education attained and health literacy; and occupation(s), work shift, and occupational safety are some of the factors that will influence the success of the intervention. Incorporating these factors into the clinical assessment could uncover obstacles requiring alternative or additional interventions.

As previously discussed, Hispanics/Latinos at risk of type 2 DM often also have other cardiometabolic factors that increase the risk for developing type 2 DM or $\operatorname{CVD}(95,146,148$, 432,433 ). While lifestyle intervention would ideally be recommended to every patient at risk, some patients would also need pharmacological therapy to control other cardiometabolic factors $(66,434)$. Prevention of use of tobacco or its cessation should also be addressed, when applicable.

The difference in prevalence of diabetes across Hispanic/ Latino heritage groups presents an opportunity to study potential genetic, biological and environmental interactions that lead to different manifestations of the disease. Deep metabolic phenotyping, (i.e., assessment of glucose homeostasis, insulin sensitivity, insulin secretion, $\alpha$-cell and $\beta$-cell function, adipose tissue distribution) along with a comprehensive clinical assessment (including age, sex, clinical presentation of the disease, detailed medical history, etc.) may uncover important differences or similarities in type $2 \mathrm{DM}$ phenotypes among Hispanic/Latino heritage groups, and biological or health determinants that could influence type 2 DM risk. Given the diversity of the Hispanic/Latino population, the feasibility of such enterprise could be addressed through collaborations like those mentioned above, exploring the use of clinical databases, and creating patient/data registries, among other potential collective efforts.

Type 2 diabetes mellitus preventive strategies have mostly focused on weight reduction, and have produced promising results. However, given the increasing prevalence of obesity in the Hispanic/Latino populations, type 2 DM diabetes and obesity preventive efforts may require even more intensive approaches, perhaps through risk stratification. Preventive efforts focusing on those at higher risk due to age, health status, medications, sedentary lifestyle, family history of type 2 DM or GDM might be different than the strategies for those who have lower susceptibility. The timing of prevention should also be considered. Earlier onset of obesity has been associated with higher risk of developing type 2 DM (173-175), for example. Also, risk stratification should be carefully determined and considering all factors mentioned above. For instance, the DPP reported that over a 10-year follow-up period from randomization, the initial differences in incident diabetes among treatment arms, including the lifestyle intervention, began to narrow (435). Through a retrospective analysis, the investigators examined participants' susceptibility to type $2 \mathrm{DM}$, including genetic risk scores (GRSs) $(435,436)$. The investigators concluded that although clinical and genetic susceptibility could influence risk to develop type $2 \mathrm{DM}$, GRS alone did not determine the success of the lifestyle intervention; at the highest quartile of GRS, intensive lifestyle intervention was effective at reducing risk $(435,436)$.

Few behaviors are as closely tied to culture as diet and selfcare. What, when, and how much we eat, as well as our notions of health and disease, including whose advice we seek, are firmly grounded in the cultural context which shapes us. It may influence beliefs about what causes diabetes, whether to engage in type $2 \mathrm{DM}$ risk-reduction activities, seek advice regarding the disease, and decide which treatment options are followed. Despite their impact on health and disease management, cultural considerations are often an afterthought in the development and implementation of preventive or treatment interventions targeting type $2 \mathrm{DM}$ in Hispanic/Latino populations. A recent review found only 12 published studies on behavioral interventions aimed at reduction of type $2 \mathrm{DM}$ and specifically designed for Hispanic/Latino adults (380). All interventions were offered in Spanish and took place in community settings, and nine included materials for individuals of low literacy. However, only two included Hispanic/Latino foods or recipes, community 
input in the intervention content, and addressed cultural beliefs regarding diabetes. Thus, it appears that for most studies, the process of infusing culture into interventions remains at the surface structures (language and setting in which intervention is delivered), without fully incorporating cultural values and elements into intervention messages, materials, design, and implementation (437). Given the evidence that culturally coherent behavioral interventions for diabetes prevention/management among Hispanic/Latino groups are more effective than usual care in improving $\mathrm{HbA} 1 \mathrm{c}$, weight/body mass index, lipid, blood pressure, dietary intake, PA, and diabetes knowledge (438), there is a strong case for ensuring the presence of cultural-competency components in every diabetes-related healthcare service intervention. Cultural competence must be at the core of clinical care and the design and implementation of research studies and large-scale interventions.

Lifestyle intervention studies to prevent type $2 \mathrm{DM}$ in Hispanics/Latinos have mostly been focused on short-term goals of weight reduction, and increasing PA. While they have demonstrated modest success at meeting these goals, follow-up periods have been insufficiently long to demonstrate prevention or delay of type $2 \mathrm{DM}$. Initiating lifestyle interventions before pregnancy (to prevent GDM, for example), and improving representation of women of various Hispanic/Latino heritage groups, should be seriously considered. Studies focused on children and adolescents could explore the impact of factors, such as maternal health, prenatal care, and child's development on preventive interventions. Advances in the field will require funding opportunities that allow for longer follow-up periods, permit the examination of interventions and outcomes for different Hispanic/Latino populations, and allow for comparisons of various elements of cultural adaptation. On the other hand, integrating research interventions within established clinical settings or health systems could be resource-efficient way to implement research studies on type $2 \mathrm{DM}$ prevention, including the follow-up of research study participants.

Quality of life and savings in disability-adjusted life years resulting from delaying the onset of type 2 DM should be quantified and qualified, especially among high-risk populations like Hispanics/Latinos. Also, the evaluation of type 2 DM risk prevention in multilevel community studies to prevent childhood obesity $(331,332)$, coupled with mass media campaigns to increase awareness of type $2 \mathrm{DM}$ prevention $(336,439)$, and other risk factors for diabetes, is warranted.

The success of large culturally tailored interventions, such as those modeled after the DPP, underscore the promise that such interventions might result in improved quality of life, higher productivity, and reduced morbidity and mortality for Hispanic/Latino populations. However, it is critical to remain aware that the vast heterogeneity in the Hispanic/Latino population requires clinicians and researchers alike to avoid relying on vague and largely unexamined concepts, such as familism and marianism without first verifying their relevance in the population of interest. Often, the uncritical acceptance of these values as omnipresent in individuals of Hispanic/Latino origin results in the automatic assumptions that, for example, interventions must be family based. Upon closer examination, studies have found that the Hispanic family unit is much more complex, and less unconditionally supportive, than it is often assumed to be, and in many cases, some Hispanic/Latino women prefer women-only group interventions without the inhibiting presence of family members, children, or spouses $(440,441)$.

In both clinical and research programs, engagement of stakeholders, not only including the patient population and the healthcare provider team, but also administrative clinic and research staff, is critical for the success of health-promotion interventions. A bidirectional communication style, from clinicians/investigators to patients and community, is necessary to ensure the cultural coherence, accessibility, and sustainability of a program. Individuals who are thoroughly competent in the cultural, socioeconomic, and even geographic context of the target population can navigate cultural nuances of these heterogeneous populations and provide invaluable guidance in the design and implementation of both large- and small-scale preventive and treatment efforts.

Upon designing a research project or implementing a clinical program to prevent type $2 \mathrm{DM}$ in Hispanics/Latinos in the US and in Latin America, other challenges need to be acknowledged. Insufficient institutional (government, academic, etc.) interest or commitment, lack of public awareness on the importance of prevention, insufficient financial and human resources, and political issues are some of the challenges faced across the continent (442-444). Whereas out of the scope of this review, proposed models of an international collaborative initiative (442) and of an implementation cycle and a translatability scale for identifying and implementing effective solutions to address the rising burden of chronic diseases in low-middle income countries, specifically CVD (444), might set the stage for future type 2 DM prevention initiatives in the continent.

The progressive and sustained increase in type $2 \mathrm{DM}$ among Hispanics/Latinos is a clear indicator that preventive efforts need to be seriously and urgently reframed. This will require a better understanding of the extent and etiology of the disease, creating solutions through multidisciplinary approaches, and a fundamentally radical transformation in our priorities as individuals and as communities.

\section{AUTHOR CONTRIBUTIONS}

MLAS conceptualized the manuscript. MLAS, UCR, FJP, JM, NML and CMP researched the literature, wrote different sections of the manuscript, reviewed the manuscript in its entirety, and approved its final version. MLAS and NML did the final review and editing of the manuscript.

\section{ACKNOWLEDGMENTS}

The authors would like to acknowledge and thank Dr. Jean L. Olson and Ms. Jill A. Pope for their valuable comments and edits. 


\section{REFERENCES}

1. García-Márquez G. No one writes to the colonel. 1st ed. In: García-Márquez G, editor. Collected Novellas. New York, NY: Harper Perennial (1991). 152 p.

2. Jacome Roca A. Diabetes en Colombia: Recuento Histórico y Bibliográfico. (2013). Available from: http://encolombia.com/medicina/revistas-medicas/ d-diabetes/d22/historia-y-bibliografia/

3. Scolpini V. Historia de la diabetes en el Uruguay. Arch Pediatr Urug (1982) 53:245-59.

4. World Health Organization. The Top 10 Causes of Death. (2017). Available from: http://www.who.int/mediacentre/factsheets/fs310/en/

5. United States Census Bureau. Profile America Facts for Features, CB16-FF.16 Hispanic Heritage Month. (2016). Available from: http://census.gov/newsroom/facts-for-features/2016/cb16-ff16.html

6. Colby SL, Ortman JM. Projections of the Size and Composition of the US Population: 2014-2060, Current Population Reports 2015; P25-1143. Washington, DC: US Census Bureau (2014).

7. Patten E. The Nation's Latino Population Is Defined by Its Youth. Pew Research Center, Hispanic Trends (2016). Available from: http://www.pewhispanic. org/2016/04/20/the-nations-latino-population-is-defined-by-its-youth/

8. Menke A, Casagrande SS, Geiss L, Cowie CC. Prevalence of and trends in diabetes among adults in the United States, 1988-2012. JAMA (2015) 314: 1021-9. doi:10.1001/jama.2015.10029

9. Alegre-Díaz J, Herrington W, López-Cervantes M, Gnautic L, Ramírez R, Hill M, et al. Diabetes and cause-specific mortality in Mexico City. N Engl J Med (2016) 375:1961-71. doi:10.1056/NEJMoa1605368

10. Colón-Ramos U, Rodríguez-Ayuso I, Gebrekristos HT, Roess A, Pérez CM, Simonsen L. Transnational mortality comparisons between archipelago and mainland Puerto Ricans. J Immigr Minor Health (2017) 19:1009-17. doi:10.1007/s10903-016-0448-5

11. Flegal KM, Ezzati TM, Harris MI, Haynes SG, Juarez RZ, Knowler WC, et al. Prevalence of diabetes in Mexican Americans, Cubans, and Puerto Ricans from the Hispanic Health and Nutrition Examination Survey, 1982-1984. Diabetes Care (1991) 14:628-38. doi:10.2337/diacare.14.7.628

12. Schneiderman N, Llabre M, Cowie CC, Barnhart J, Carnethon M, Gallo LC, et al. Prevalence of diabetes among Hispanics/Latinos from diverse backgrounds: the Hispanic Community Health Study/Study of Latinos (HCHS/ SOL). Diabetes Care (2014) 37:2233-9. doi:10.2337/dc13-2939

13. Avilés-Santa ML, Schneiderman N, Savage PJ, Kaplan RC, Teng Y, Pérez CM, et al. Identifying probable diabetes mellitus among Hispanics/Latinos from four U.S. cities: findings from the Hispanic Community Health Study/Study of Latinos. Endocr Pract (2016) 22:1151-60. doi:10.4158/EP151144.OR

14. Humes KR, Jones NA, Ramirez RR. Overview of Race and Hispanic Origin: 2010; 2010 Census Briefs. (2011). Available from: https://www.census.gov/ prod/cen2010/briefs/c2010br-02.pdf

15. Interim Report to the Office of Management and Budget. Review of Standards for Maintaining, Collecting, and Presenting Federal Data on Race and Ethnicity. (2017). Available from: https://www.whitehouse.gov/sites/ whitehouse.gov/files/briefing-room/presidential-actions/related-omb-material/r_e_iwg_interim_report_022417.pdf

16. Ennis SR, Ríos-Vargas M, Albert NG. The Hispanic Population: 2010, 2010 Census Briefs. Suitland, MD: U.S. Department of Commerce Economics and Statistics Administration, U.S. Census Bureau (2011).

17. Lopez MH. Hispanic or Latino? Many Don't Care, Except in Texas. Pew Research Center (2013). Available from: http://www.pewresearch.org/fact$\operatorname{tank} / 2013 / 10 / 28 /$ in-texas-its-hispanic-por-favor/

18. Lopez MH. Hispanic Identity. Pew Research Center Hispanic Trends (2013). Available from: http://www.pewhispanic.org/2013/ 10/22/3-hispanic-identity/

19. Diccionario de la Real Academia Española de la Lengua. (2017). Available from: http://lema.rae.es/dpd/?key=hispanoamerica

20. Legorburu J. Lengua y Literatura II. Madrid, Spain: Ediciones S.M. Madrid (1980). p. 24-6.

21. U.S. Census Bureau. American Community Survey 1-Year Estimates. (2015). Available from: https://factfinder.census.gov/faces/nav/jsf/pages/ community facts.xhtml

22. Stepler R, Brown A. Statistical Portrait of Hispanics in the United States. (2017). Available from: http://www.pewhispanic.org/2016/04/19/statisticalportrait-of-hispanics-in-the-united-states-trends/
23. United States Census Bureau. Facts for Figures: Hispanic Heritage Month 2016. (2016). Release Number: CB16-FF.16.

24. Ortman JM, Guarnieri CE. United States Population Projections: 2000-2050. National Population Projections (2009). Available from: https://www.census. gov/library/working-papers/2009/demo/us-pop-proj-2000-2050.html

25. U.S. Census Bureau American FactFinder. 2011-2015 American Community Survey 5-Year Estimates. U.S. Census Bureau (2017). Available from: https://factfinder.census.gov/faces/tableservices/jsf/pages/productview. xhtml?pid=ACS_15_5YR_S1501\&src=pt

26. Proctor BD, Semega JL, Kollar MA. U.S. Census Bureau, Current Population Reports, P60-256(RV), Income and Poverty in the United States: 2015. Washington, DC: U.S. Government Printing Office (2016).

27. Smith J, Medalia C. US Census Bureau, Current Population Reports, P 60-253 Health Insurance Coverage in the United States: 2014. Washington, DC: US Government Printing Office (2015).

28. Cohen RA, Martinez ME. Health Insurance Coverage: Early Release of Estimates from the National Health Interview Survey, January-March 2014. Atlanta: National Center for Health Statistics (2014). Available from: https:// www.cdc.gov/nchs/data/nhis/earlyrelease/insur201409.pdf

29. Penedo FJ, Yanez B, Castañeda SF, Gallo L, Wortman K, Gouskova N, et al. Self-reported cancer prevalence among Hispanics in the US: results from the Hispanic Community Health Study/Study of Latinos. PLoS One (2016) 11:e0146268. doi:10.1371/journal.pone.0146268

30. United Nations Department of Economic and Social Affairs/Population Division. World Population Prospects: The 2015 Revision, Key Findings and Advance Tables. New York (2015). Available from: https://esa.un.org/unpd/ wpp/publications/

31. CEPAL (Comisión Económica para América Latina y el Caribe/Economic Commission for Latin America and the Caribbean). Anuario estadístico de America Latina y El Caribe/Statistical Yearbook for Latin America and the Caribbean. (2017). Available from: https://www.cepal.org/en/publications/ type/anuario-estadistico-america-latina-caribe-statistical-yearbook-latinamerica-and

32. U.S. Commission on Civil Rights. Counting the Forgotten: The 1970 Census Count of Persons of Spanish Speaking Background in the United States. (2017). Available from: https://www.law.umaryland.edu/marshall/usccr/ documents/cr12sp22970.pdf

33. Moy CS. Determining ethnic origin in an interview survey: problems and recommendations. Public Health Rep (1977) 92:414-20.

34. Goldberg B. Tuberculosis in racial types with special reference to Mexicans. Am J Pub Health (1929) 19:274-84. doi:10.2105/AJPH.19.3.274

35. Gregg R. Medical examination and vaccination of farm laborers recruited from Mexico. Public Health Rep (1950) 65:807-9. doi:10.2307/4587381

36. Keissman JJ. The curandero's apprentice: a therapeutic integration of folk and medical care. Am J Psychiatry (1975) 132:81-3. doi:10.1176/ajp.132.1.81

37. Garrison V. Support systems of schizophrenic and nonschizophrenic Puerto Rican migrant women in New York City. Schizophr Bull (1978) 4:561-96. doi:10.1093/schbul/4.4.561

38. Suffet F, Brotman R. Employment and social disability among opiate addicts. Am J Drug Alcohol Abuse (1976) 3:387-95. doi:10.3109/ 00952997609014281

39. Kline LY. Some factors in the psychiatric treatment of Spanish-Americans. Am J Psychiatry (1969) 125:1674-81. doi:10.1176/ajp.125.12.1674

40. Mirowsky J II, Ross CE. Minority status, ethnic culture, and distress: a comparison of blacks, whites, Mexicans, and Mexican Americans. AJS (1980) 86:479-95.

41. Klerman LV, Jones JG, Hull MC. Puerto Ricans in a small U.S. city. Public Health Rep (1966) 81:369-76. doi:10.2307/4592720

42. Hoppe SK, Leon RL. Coping in the barrio: case studies of MexicanAmerican families. Child Psychiatry Hum Dev (1977) 7:264-75. doi:10.1007/ BF01433935

43. Kuttner RE, Mailander JC. Serum pepsinogen in migrant Mexicans and stressed Caucasians. J Natl Med Assoc (1965) 57:109-11.

44. Drake G, Carpenter CM, Dunn JE. Further studies on the frequency of achlorydria among Mexicans in Los Angeles. J Natl Cancer Inst (1962) 28:853-7.

45. Carmel R, Johnson CS. Racial patterns in pernicious anemia. Early age at onset and increased frequency of intrinsic-factor antibody in black women. N Engl J Med (1978) 298:647-50. doi:10.1056/NEJM197803232981203 
46. Schenk EA, Kilpstein FA, Tomasini JT. Morphologic characteristics of jejunal biopsies from asymptomatic Haitians and Puerto Ricans. Am J Clin Nutr (1972) 25:1080-3.

47. Winsberg GR, Sonnenschein E, Dyer AR, Schnadig V, Bonilla E. Prevalence of intestinal parasites in Latino residents of Chicago. Am J Epidemiol (1975) 102:526-32. doi:10.1093/oxfordjournals.aje.a112190

48. Mascola L, Pelosi R, Blount JH, Binkin NJ, Alexander CE, Cates W Jr. Congenital syphilis. Why is it still occurring? JAMA (1984) 5:1719-22.

49. Vandow JE. Venereal disease among Puerto Ricans in New York City. Public Health Rep (1955) 70:1242-6. doi:10.2307/4589333

50. Hernandez A. Chicanas and the issue of involuntary sterilization: reforms needed to protect inform consent. Chicano Law Rev (1976) 3:3-37.

51. Dawber TR, Meadors GF, Moore FE. Epidemiological approaches to heart disease: the Framingham study. Am J Public Health Nations Health (1951) 41:279-81. doi:10.2105/AJPH.41.3.279

52. Dawber TR, Moore FE, Mann GV. Coronary heart disease in the Framingham study. Am J Public Health Nations Health (1957) 47:4-24. doi:10.2105/ AJPH.47.4_Pt_2.4

53. Dawber TR, Kannel WB, Revotskie N, Stokes J III, Kagan A, Gordon T. Some factors associated with the development of coronary heart disease: six years' follow-up experience in the Framingham study. Am J Public Health Nations Health (1959) 49:1349-56. doi:10.2105/AJPH.49.10.1349

54. Cruz-Vidal M, Costas R, Garcia-Palmieri MR, Sorlie PD, Hertzmark E. Factors related to diabetes mellitus in Puerto Rican men. Diabetes (1979) 28:300-7. doi:10.2337/diab.28.4.300

55. Cruz-Vidal M, García-Palmieri MR, Costas R, Sorlie PD, Havlik RJ. Abnormal blood glucose and coronary heart disease: the Puerto Rico Heart Health Program. Diabetes Care (1983) 6:556-61. doi:10.2337/diacare.6.6.556

56. Gaskill SP, Allen CR, Garza V, Gonzales JL, Waldrop RH. Cardiovascular risk factors in Mexican Americans in Laredo, Texas: I. Prevalence of overweight and diabetes and distributions of serum lipids. Am JEpidemiol (1981) 113:546-55. doi:10.1093/oxfordjournals.aje.a113131

57. Gunby P. San Antonio Heart Study compares ethnic groups. JAMA (1980) 244:225. doi:10.1001/jama.244.3.225a

58. Stern MP, Pugh JA, Gaskill SP, Hazuda HP. Knowledge, attitudes, and behavior related to obesity and dieting in Mexican Americans and Anglos: the San Antonio Heart Study. Am J Epidemiol (1982) 115:917-28. doi:10.1093/ oxfordjournals.aje.a113379

59. Delgado JL, Johnson CL, Treviño FM. Hispanic health nutrition and examination survey: methodological considerations. Am J Public Health (1990) 80(Suppl):6-10. doi:10.2105/AJPH.80.Suppl.6

60. Crespo C, Loria C, Burt V. Hypertension and other cardiovascular disease risk factors among Mexican Americans, Cuban Americans, and Puerto Ricans from the Hispanic Health and Nutrition Examination Survey. Public Health Rep (1996) 111(Suppl 2):7-10.

61. Hamman RF, Marshall JA, Baxter J, Kahn LB, Mayer EJ, Orleans M, et al. Methods and prevalence of non-insulin-dependent diabetes mellitus in a biethnic Colorado population, the San Luis Valley Diabetes Study. Am J Epidemiol (1989) 129:295-311. doi:10.1093/oxfordjournals.aje.a115134

62. Behavioral Risk Factor Surveillance System. (2017). Available from: https:// www.cdc.gov/brfss/

63. National Center for Health Statistics. National Health and Nutrition Examination Survey. (2017). Available from: https://www.cdc.gov/nchs/ nhanes/

64. Sorlie PD, Avilés-Santa ML, Wassertheil-Smoller S, Kaplan RC, Daviglus ML, Giachello A, et al. Design and implementation of the Hispanic Community Health Study/Study of Latinos. Ann Epidemiol (2010) 20:629-41. doi:10.1016/ j.annepidem.2010.03.015

65. LaVange LM, Kalsbeek W, Sorlie PD, Avilés-Santa ML, Kaplan RC, Barnhart J, et al. Sample design and cohort selection in the Hispanic Community Health Study/Study of Latinos. Ann Epidemiol (2010) 20:642-9. doi:10.1016/j. annepidem.2010.05.006

66. American Diabetes Association. Classification and diagnosis of diabetes. Diabetes Care (2017) 40(Suppl 1):S11-24. doi:10.2337/dc17-S005

67. World Health Organization. Use of Glycated Haemoglobin (HbAlc) in the Diagnosis of Diabetes Mellitus. Abbreviated Report of a WHO Consultation. World Health Organization (2011). Available from: http://www.who.int/ diabetes/publications/report-hbalc_2011.pdf?ua $=1$
68. World Health Organization. Definition and Diagnosis of Diabetes Mellitus and Intermediate Hyperglycemia. Report of a WHO/IDF Consultation. World Health Organization (2006). Available from: http://apps.who.int/iris/ bitstream/10665/43588/1/9241594934_eng.pdf

69. Hanis CL, Ferrell RE, Barton SA, Aguilar L, Garza-Ibarra A, Tulloch BR, et al. Diabetes among Mexican Americans in Starr County, Texas. Am J Epidemiol (1983) 118:659-72. doi:10.1093/oxfordjournals.aje.a113677

70. Samet JM, Coultas DB, Howard CA, Skipper BJ, Hanis CL. Diabetes, gallbladder disease, obesity, and hypertension among Hispanics in New Mexico. Am J Epidemiol (1988) 128:1302-11. doi:10.1093/oxfordjournals.aje.a115083

71. Hamman RF, Mayer EJ, Moo-Young GA, Hildebrandt W, Marshall JA, Baxter J. Prevalence and risk factors of diabetic retinopathy in non-Hispanic whites and Hispanics with NIDDM. San Luis Valley Diabetes Study. Diabetes (1989) 38:1231-7. doi:10.2337/diab.38.10.1231

72. Mitchell BD, Stern MP, Haffner SM, Hazuda HP, Patterson JK. Risk factors for cardiovascular mortality in Mexican Americans and non-Hispanic whites: the San Antonio Heart Study. Am J Epidemiol (1990) 131:423-33. doi:10.1093/oxfordjournals.aje.a115517

73. Haddock L, de Conty IT. Prevalence rates for diabetes mellitus in Puerto Rico. Diabetes Care (1991) 14:676-84. doi:10.2337/diacare.14.7.676

74. Stern MP, Gonzalez C, Mitchell BD, Villalpando E, Haffner SM, Hazuda HP. Genetic and environmental determinants of type II diabetes in Mexico City and San Antonio. Diabetes (1992) 41:484-92. doi:10.2337/diab.41.4.484

75. Williams DE, Cadwell BL, Cheng YJ, Cowie CC, Gregg EW, Geiss LS, et al. Prevalence of impaired fasting glucose and its relationship with cardiovascular disease risk factors in US adolescents, 1999-2000. Pediatrics (2005) 116:1122-6. doi:10.1542/peds.2004-2001

76. Lee JM, Okumura MJ, Davis MM, Herman WH, Gurney JG. Prevalence and determinants of insulin resistance among U.S. adolescents: a populationbased study. Diabetes Care (2006) 29:2427-32. doi:10.2337/dc06-0709

77. Ioannou GN, Bryson CL, Boyko EJ. Prevalence and trends of insulin resistance, impaired fasting glucose, and diabetes. J Diabetes Complications (2007) 21:363-70. doi:10.1016/j.jdiacomp.2006.07.005

78. Allison MA, Budoff MJ, Wong ND, Blumenthal RS, Schreiner PJ, Criqui $\mathrm{MH}$. Prevalence of and risk factors for subclinical cardiovascular disease in selected US Hispanic ethnic groups: the multi-ethnic study of atherosclerosis. Am J Epidemiol (2008) 167:962-9. doi:10.1093/aje/kwm402

79. Cowie CC, Rust KF, Ford ES, Eberhardt MS, Byrd-Holt DD, Li C, et al. Full accounting of diabetes and pre-diabetes in the U.S. population in 1988-1994 and 2005-2006. Diabetes Care (2009) 32:287-94. doi:10.2337/dc08-1296

80. Li C, Ford ES, Zhao G, Mokdad AH. Prevalence of pre-diabetes and its association with clustering of cardiometabolic risk factors and hyperinsulinemia among U.S. adolescents: National Health and Nutrition Examination Survey 2005-2006. Diabetes Care (2009) 32:342-7. doi:10.2337/dc08-1128

81. Derby CA, Wildman RP, McGinn AP, Green RR, Polotsky AJ, Ram KT, et al. Cardiovascular risk factor variation within a Hispanic cohort: SWAN, the Study of Women's Health Across the Nation. Ethn Dis (2010) 20:396-402.

82. Díaz-Apodaca BA, Ebrahim S, McCormack V, de Cosío FG, RuizHolguín R. Prevalence of type 2 diabetes and impaired fasting glucose: cross-sectional study of multiethnic adult population at the United StatesMexico border. Rev Panam Salud Publica (2010) 28:174-81. doi:10.1590/ S1020-49892010000900007

83. Centers for Disease Control and Prevention (CDC). Increasing prevalence of diagnosed diabetes - United States and Puerto Rico, 1995-2010. MMWR Morb Mortal Wkly Rep (2012) 61:918-21.

84. Daviglus ML, Talavera GA, Avilés-Santa ML, Allison M, Cai J, Criqui MH, et al. Prevalence of major cardiovascular risk factors and cardiovascular diseases among Hispanic/Latino individuals of diverse backgrounds in the United States. JAMA (2012) 308:1775-84. doi:10.1001/jama.2012.14517

85. Hunt KJ, Gebregziabher M, Egede LE. Racial and ethnic differences in cardio-metabolic risk in individuals with undiagnosed diabetes: National Health and Nutrition Examination Survey 1999-2008. J Gen Intern Med (2012) 27:893-900. doi:10.1007/s11606-012-2023-7

86. Rodriguez F, Hicks LS, Lopez L. Association of acculturation and country of origin with self-reported hypertension and diabetes in a heterogeneous Hispanic population. BMC Public Health (2012) 12:768. doi:10.1186/14712458-12-768 
87. Bullard KM, Saydah SH, Imperatore G, Cowie CC, Gregg EW, Geiss LS, et al. Secular changes in U.S. Prediabetes prevalence defined by hemoglobin Alc and fasting plasma glucose: National Health and Nutrition Examination Surveys, 1999-2010. Diabetes Care (2013) 36:2286-93. doi:10.2337/dc12-2563

88. Dabelea D, Mayer-Davis EJ, Saydah S, Imperatore G, Linder B, Divers J, et al. Prevalence of type 1 and type 2 diabetes among children and adolescents from 2001 to 2009. JAMA (2014) 311:1778-86. doi:10.1001/jama.2014.3201

89. Pettitt DJ, Talton J, Dabelea D, Divers J, Imperatore G, Lawrence JM, et al. Prevalence of diabetes in U.S. youth in 2009: the SEARCH for diabetes in youth study. Diabetes Care (2014) 37:402-8. doi:10.2337/dc13-1838

90. Selvin E, Parrinello CM, Sacks DB, Coresh J. Trends in prevalence and control of diabetes in the United States, 1988-1994 and 1999-2010. Ann Intern Med (2014) 160:517-25. doi:10.7326/M13-2411

91. Arroyo-Johnson C, Mincey KD, Ackermann N, Milam L, Goodman MS, Colditz GA. Racial and ethnic heterogeneity in self-reported diabetes prevalence trends across Hispanic subgroups, National Health Interview Survey, 1997-2012. Prev Chronic Dis (2016) 13:E10. doi:10.5888/pcd13.150260

92. Isasi CR, Parrinello CM, Ayala GX, Delamater AM, Perreira KM, Daviglus ML, et al. Sex differences in cardiometabolic risk factors among Hispanic/Latino youth. J Pediatr (2016) 176:121-7.e1. doi:10.1016/j.jpeds.2016.05.037

93. Hanis CL, Redline S, Cade BE, Bell GI, Cox NJ, Below JE, et al. Beyond type 2 diabetes, obesity and hypertension: an axis including sleep apnea, left ventricular hypertrophy, endothelial dysfunction, and aortic stiffness among Mexican Americans in Starr County, Texas. Cardiovasc Diabetol (2016) 15:86. doi:10.1186/s12933-016-0405-6

94. Menke A, Casagrande S, Cowie CC. Prevalence of diabetes in adolescents aged 12 to 19 years in the United States, 2005-2014. JAMA (2016) 316:344-5. doi:10.1001/jama.2016.8544

95. Avilés-Santa ML, Pérez CM, Schneiderman N, Savage PJ, Kaplan RC, Teng Y, et al. Detecting prediabetes among Hispanics/Latinos from diverse heritage groups: does the test matter? Findings from the Hispanic Community Health Study/Study of Latinos. Prev Med (2017) 95:110-8. doi:10.1016/j. ypmed.2016.12.009

96. Stark Casagrande S, Fradkin JE, Saydah SH, Rust KF, Cowie CC. The prevalence of meeting A1C, blood pressure, and LDL goals among people with diabetes, 1988-2010. Diabetes Care (2013) 36:2271-9. doi:10.2337/dc12-2258

97. Schneiderman N, Llabre MM, Chirinos DA, Teng Y, Cai J, Cowie CC, et al. Diversity in diabetes status and cardiovascular disease in the Longitudinal Hispanic Community Health Study. Circulation (2017) 135(Suppl 1):A075.

98. Menke A, Casagrande SS, Avilés-Santa ML, Cowie CC. Factors associated with being unaware of having diabetes. Diabetes Care (2017) 40:e55-6. doi:10.2337/dc16-2626

99. Haffner SM, Hazuda HP, Mitchell BD, Patterson JK, Stern MP. Increased incidence of type II diabetes mellitus in Mexican Americans. Diabetes Care (1991) 14:102-8. doi:10.2337/diacare.14.7.665

100. Baxter J, Hamman RF, Lopez TK, Marshall JA, Hoag S, Swenson CJ. Excess incidence of known non-insulin-dependent diabetes mellitus (NIDDM) in Hispanics compared with non-Hispanic whites in the San Luis Valley, Colorado. Ethn Dis (1993) 3:11-21.

101. Burke JP, Williams K, Gaskill SP, Hazuda HP, Haffner SM, Stern MP. Rapid rise in the incidence of type 2 diabetes from 1987 to 1996: results from the San Antonio Heart Study. Arch Intern Med (1999) 159:1450-6. doi:10.1001/ archinte.159.13.1450

102. Burke JP, Williams K, Haffner SM, Villalpando CG, Stern MP. Elevated incidence of type 2 diabetes in San Antonio, Texas, compared with that of Mexico City, Mexico. Diabetes Care (2001) 24:1573-8. doi:10.2337/ diacare.24.9.1573

103. Lawrence JM, Mayer-Davis EJ, Reynolds K, Beyer J, Pettitt DJ, D’Agostino RB Jr, et al. Diabetes in Hispanic American youth: prevalence, incidence, demographics, and clinical characteristics: the SEARCH for diabetes in youth study. Diabetes Care (2009) 32(Suppl 2):S123-32. doi:10.2337/dc09-S204

104. Fuhrman BJ, Smit E, Crespo CJ, Garcia-Palmieri MR. Coffee intake and risk of incident diabetes in Puerto Rican men: results from the Puerto Rico Heart Health Program. Public Health Nutr (2009) 12:842-8. doi:10.1017/ S1368980008003303

105. Tabaei BP, Chamany S, Driver CR, Kerker B, Silver L. Incidence of selfreported diabetes in New York city, 2002, 2004, and 2008. Prev Chronic Dis (2012) 9:110320. doi:10.5888/pcd9.110320
106. Mayer-Davis EJ, Lawrence JM, Dabelea D, Divers J, Isom S, Dolan L, et al. Incidence trends of type 1 and type 2 diabetes among youths, 2002-2012. N Engl J Med (2017) 376:1419-29. doi:10.1056/NEJMoa1610187

107. Berkowitz GS, Lapinski RH, Wein R, Lee D. Race/ethnicity and other risk factors for gestational diabetes. Am J Epidemiol (1992) 135:965-73. doi:10.1093/oxfordjournals.aje.a116408

108. Solomon CG, Willett WC, Carey VJ, Rich-Edwards J, Hunter DJ, Colditz GA, et al. A prospective study of pregravid determinants of gestational diabetes mellitus. JAMA (1997) 278:1078-83. doi:10.1001/jama.1997.03550130052036

109. Ferrara A, Kahn HS, Quesenberry C, Riley C, Hedderson MM. An increase in the incidence of gestational diabetes mellitus: Northern California, 1991-2000. Obstet Gynecol (2004) 103:526-33. doi:10.1097/01.AOG. 0000113623.18286 .20

110. Savitz DA, Janevic TM, Engel SM, Kaufman JS, Herring AH. Ethnicity and gestational diabetes in New York city, 1995-2003. BJOG (2008) 115:969-78. doi:10.1111/j.1471-0528.2008.01763.x

111. Chu SY, Abe K, Hall LR, Kim SY, Njoroge T, Qin C. Gestational diabetes mellitus: all Asians are not alike. Prev Med (2009) 49:265-8. doi:10.1016/j. ypmed.2009.07.001

112. Kim SY, Saraiva C, Curtis M, Wilson HG, Troyan J, Sharma AJ. Fraction of gestational diabetes mellitus attributable to overweight and obesity by race/ ethnicity, California, 2007-2009. Am J Public Health (2013) 103:e65-72. doi:10.2105/AJPH.2013.301469

113. Bardenheier BH, Imperatore G, Gilboa SM, Geiss LS, Saydah SH, Devlin HM, et al. Trends in gestational diabetes among hospital deliveries in 19 U.S. States, 2000-2010. Am J Prev Med (2015) 49:12-9. doi:10.1016/j.amepre.2015.01.026

114. Bardenheier BH, Imperatore G, Devlin HM, Kim SY, Cho P, Geiss LS. Trends in pre-pregnancy diabetes among deliveries in 19 U.S. states, 2000-2010. Am J Prev Med (2015) 48:154-61. doi:10.1016/j.amepre.2014.08.031

115. Malerbi DA, Franco LJ. Multicenter study of the prevalence of diabetes mellitus and impaired glucose tolerance in the urban Brazilian population aged 30-69 yr. The Brazilian Cooperative Group on the Study of Diabetes Prevalence. Diabetes Care (1992) 15:1509-16. doi:10.2337/diacare.15.11.1509

116. Oliveira JE, Milech A, Franco LJ. The prevalence of diabetes in Rio de Janeiro, Brazil. The Cooperative Group for the Study of Diabetes Prevalence in Rio De Janeiro. Diabetes Care (1996) 19:663-6. doi:10.2337/diacare.19.6.663

117. Barceló A, Daroca MC, Ribera R, Duarte E, Zapata A, Vohra M. Diabetes in Bolivia. Rev Panam Salud Publica (2001) 10:318-23.

118. Torquato MT, Montenegro Júnior RM, Viana LA, de Souza RA, Lanna CM, Lucas JC, et al. Prevalence of diabetes mellitus and impaired glucose tolerance in the urban population aged 30-69 years in Ribeirão Preto (São Paulo), Brazil. Sao Paulo Med J (2003) 121:224-30. doi:10.1590/S1516-31802003000600002

119. Aguilar-Salinas CA, Velazquez Monroy O, Gómez-Pérez FJ, Gonzalez Chávez A, Esqueda AL, Molina Cuevas V, et al. Characteristics of patients with type 2 diabetes in México: results from a large population-based nationwide survey. Diabetes Care (2003) 26:2021-6. doi:10.2337/diacare.26.7.2021

120. Sereday MS, Gonzalez C, Giorgini D, De Loredo L, Braguinsky J, Cobeñas C, et al. Prevalence of diabetes, obesity, hypertension and hyperlipidemia in the central area of Argentina. Diabetes Metab (2004) 30:335-9. doi:10.1016/ S1262-3636(07)70125-8

121. Sánchez-Castillo CP, Velásquez-Monroy O, Lara-Esqueda A, Berber A, Sepulveda J, Tapia-Conyer R, et al. Diabetes and hypertension increases in a society with abdominal obesity: results of the Mexican National Health Survey 2000. Public Health Nutr (2005) 8:53-60. doi:10.1079/PHN2004659

122. Albala C, Lebrão ML, León Díaz EM, Ham-Chande R, Hennis AJ, Palloni A, et al. The health, well-being, and aging ("SABE") survey: methodology applied and profile of the study population. Rev Panam Salud Publica (2005) 17:307-22. doi:10.1590/S1020-49892005000500003

123. Barceló A, Peláez M, Rodriguez-Wong L, Pastor-Valero M. The prevalence of diagnosed diabetes among the elderly of seven cities in Latin America and the Caribbean: the health wellbeing and aging (SABE) project. J Aging Health (2006) 18:224-39. doi:10.1177/0898264305285728

124. Barceló A, Gregg EW, Pastor-Valero M, Robles SC. Waist circumference, BMI and the prevalence of self-reported diabetes among the elderly of the United States and six cities of Latin America and the Caribbean. Diabetes Res Clin Pract (2007) 78:418-27. doi:10.1016/j.diabres.2007.06.008

125. Meaney E, Lara-Esqueda A, Ceballos-Reyes GM, Asbun J, Vela A, MartínezMarroquín Y, et al. Cardiovascular risk factors in the urban Mexican 
population: the FRIMEX study. Public Health (2007) 121:378-84. doi:10.1016/ j.puhe.2006.11.008

126. Medina-Lezama J, Morey-Vargas OL, Zea-Díaz H, Bolaños-Salazar JF, Corrales-Medina F, Cuba-Bustinza C, et al. Prevalence of lifestyle-related cardiovascular risk factors in Peru: the PREVENCION study. Rev Panam Salud Publica (2008) 24:169-79. doi:10.1590/S1020-49892008000900003

127. Capilheira MF, Santos IS, Azevedo MR, Reichert FF. Risk factors for chronic non-communicable diseases and the CARMEN initiative: a populationbased study in the south of Brazil. Cad Saúde Pública (2008) 24:2767-74. doi:10.1590/S0102-311X2008001200005

128. Schargrodsky H, Hernández-Hernández R, Champagne BM, Silva $\mathrm{H}$, Vinueza R, Silva Ayçaguer LC, et al. CARMELA: assessment of cardiovascular risk in seven Latin American cities. Am J Med (2008) 121:58-65. doi:10.1016/j.amjmed.2007.08.038

129. Escobedo J, Buitrón LV, Velasco MF, Ramírez JC, Hernández R, Macchia A, et al. High prevalence of diabetes and impaired fasting glucose in urban Latin America: the CARMELA study. Diabet Med (2009) 26:864-71. doi:10.1111/j.1464-5491.2009.02795.x

130. Kuri-Morales P, Emberson J, Alegre-Díaz J, Tapia-Conyer R, Collins R, Peto $\mathrm{R}$, et al. The prevalence of chronic diseases and major disease risk factors at different ages among 150,000 men and women living in Mexico City: cross-sectional analyses of a prospective study. BMC Public Health (2009) 9:9. doi:10.1186/1471-2458-9-9

131. Burrows RA, Leiva LB, Weisstaub G, Lera LM, Albala CB, Blanco E, et al. High HOMA-IR, adjusted for puberty, relates to the metabolic syndrome in overweight and obese Chilean youths. Pediatr Diabetes (2011) 12:212-8. doi:10.1111/j.1399-5448.2010.00685.x

132. Bautista LE, Casas JP, Herrera VM, Miranda JJ, Perel P, Pichardo R, et al. The Latin American consortium of studies in obesity (LASO). Obes Rev (2009) 10:364-70. doi:10.1111/j.1467-789X.2009.00591.x

133. Miranda JJ, Herrera VM, Chirinos JA, Gómez LF, Perel P, Pichardo R, et al. Major cardiovascular risk factors in Latin America: a comparison with the United States. The Latin American consortium of studies in obesity (LASO). PLoS One (2013) 8:e54056. doi:10.1371/journal.pone.0054056

134. Aquino EM, Barreto SM, Bensenor IM, Carvalho MS, Chor D, Duncan BB, et al. Brazilian Longitudinal Study of Adult Health (ELSA-Brasil): objectives and design. Am J Epidemiol (2012) 175:315-24. doi:10.1093/ aje/kwr294

135. Schmidt MI, Hoffman JF, de Fátima Sander Diniz M, Lotufo PA, Griep RH, Bensenor IM, et al. High prevalence of diabetes and intermediate hyperglycemia - the Brazilian Longitudinal Study of Adult Health (ELSA-Brasil). Diabetol Metab Syndr (2014) 6:123. doi:10.1186/1758-5996-6-123

136. Rubinstein AL, Irazola VE, Calandrelli M, Elorriaga N, Gutierrez L, Lanas F, et al. Multiple cardiometabolic risk factors in the Southern Cone of Latin America: a population-based study in Argentina, Chile, and Uruguay. Int J Cardiol (2015) 183:82-8. doi:10.1016/j.ijcard.2015.01.062

137. McDonald Posso AJ, Bradshaw Meza RA, Mendoza Morales EA, Jaen Y, Cumbrera Ortega A, Mendoza Posada EJ. Diabetes in Panama: epidemiology, risk factors, and clinical management. Ann Glob Health (2015) 81:754-64. doi:10.1016/j.aogh.2015.12.014

138. Shen J, Kondal D, Rubinstein A, Irazola V, Gutierrez L, Miranda JJ, et al. A multiethnic study of pre-diabetes and diabetes in LMIC. Glob Heart (2016) 11:61-70. doi:10.1016/j.gheart.2015.12.015

139. Bernabé-Ortiz A, Carrillo-Larco RM, Gilman RH, Miele CH, Checkley W, Wells JC, et al. Geographical variation in the progression of type 2 diabetes in Peru: the CRONICAS cohort study. Diabetes Res Clin Pract (2016) 121:135-45. doi:10.1016/j.diabres.2016.09.007

140. Aschner P, Aguilar-Salinas C, Aguirre L, Franco L, Gagliardino JJ, de Lapertosa SG, et al. Diabetes in South and Central America: an update. Diabetes Res Clin Pract (2014) 103:238-43. doi:10.1016/j.diabres.2013.11.010

141. International Diabetes Federation. Diabetes Atlas. 7th ed. Brussels, Belgium (2015). Available from: www.diabetesatlas.org

142. Schmidt MI, Duncan BB, Reichelt AJ, Branchtein L, Matos MC, Costa e Forti A, et al. Gestational diabetes mellitus diagnosed with a 2-h 75-g oral glucose tolerance test and adverse pregnancy outcomes. Diabetes Care (2001) 24:1151-5. doi:10.2337/diacare.24.7.1151

143. González-Villalpando C, Dávila-Cervantes CA, Zamora-Macorra M, TrejoValdivia B, González-Villalpando ME. Incidence of type 2 diabetes in Mexico: results of the Mexico City diabetes study after 18 years of follow-up. Salud Publica Mex (2014) 56:11-7. doi:10.21149/spm.v56i1.7318

144. Flegal KM, Kruszon-Moran D, Carroll MD, Fryar CD, Ogden CL. Trends in obesity among adults in the United States, 2005-2014. JAMA (2016) 315:2284-91. doi:10.1001/jama.2016.6458

145. Ogden CL, Carroll MD, Lawman HG, Fryar CD, Kruszon D, Kit BK, et al. Trends in obesity prevalence among children and adolescents in the United States, 1988-1994 through 2013-2014. JAMA (2016) 315:2292-9. doi:10.1001/jama.2016.6361

146. Heiss G, Snyder ML, Teng Y, Schneiderman N, Llabre MM, Cowie C, et al. Prevalence of metabolic syndrome among Hispanics/Latinos of diverse background: the Hispanic Community Health Study/Study of Latinos. Diabetes Care (2014) 37:2391-9. doi:10.2337/dc13-2505

147. Pérez CM, Sánchez H, Ortiz AP. Prevalence of overweight and obesity and their cardiometabolic comorbidities in Hispanic adults living in Puerto Rico. J Community Health (2013) 38:1140-6. doi:10.1007/s10900-0139726-5

148. Pérez CM, Ortiz AP, Guzmán M, Suárez E. Distribution of the metabolic syndrome in adults living in the San Juan Metropolitan area of Puerto Rico. P R Health Sci J (2012) 31:114-22.

149. Benseñor IM, Guolart AC, Santos IS, Bittencourt MS, Pereira AC, Santos RD, et al. Association between a healthy cardiovascular profile and coronary artery calcium score: results from the Brazilian Longitudinal Study of Adult Health (ELSA-Brasil). Am Heart J (2016) 174:51-9. doi:10.1016/ j.ahj.2015.12.018

150. Rivera JA, De Cossio TG, Pedraza LS, Aburto TC, Sánchez TG, Martorell R. Childhood and adolescent overweight and obesity in Latin America: a systematic review. Lancet Diabetes Endocrinol (2014) 2:321-32. doi:10.1016/ S2213-8587(13)70173-6

151. Hernández-Cordero S, Cuevas-Nasu L, Morán-Ruán MC, Méndez-Gómez Humarán I, Avila-Arcos MA, Rivera-Dommarco JA. Overweight and obesity in Mexican children and adolescents during the last 25 years. Nutr Diabetes (2017) 7:e247. doi:10.1038/nutd.2016.52

152. Parra DC, Iannotti L, Gómez LF, Pachón H, Haire-Joshu D, Sarmiento OL, et al. The nutrition transition in Colombia over a decade: a novel household classification system of anthropometric measures. Arch Public Health (2015) 73:12. doi:10.1186/s13690-014-0057-5

153. Guo F, He D, Zhang W, Walton RG. Trends in prevalence, awareness, management, and control of hypertension among United States adults, 1999-2010. J Am Coll Cardiol (2012) 60:599-606. doi:10.1016/j.jacc.2012.04.026

154. Sorlie PD, Allison MA, Avilés-Santa ML, Cai J, Daviglus ML, Howard AG, et al. Prevalence of hypertension, awareness, treatment, and control in the Hispanic Community Health Study/Study of Latinos. Am J Hypertens (2014) 27:793-800. doi:10.1093/ajh/hpu003

155. Hernández-Hernández R, Silva $\mathrm{H}$, Velasco $\mathrm{M}$, Pellegrini F, Macchia $\mathrm{A}$ Escobedo J, et al. Hypertension in seven Latin American cities: the cardiovascular risk factor multiple evaluation in Latin America (CARMELA) study. J Hypertens (2010) 28:24-34. doi:10.1097/HJH.0b013e328332c353

156. Carroll MD, Kit BK, Lacher DA, Yoon SS. Total and high-density lipoprotein cholesterol in adults: National Health and Nutrition Examination Survey, 2011-2012. NHCS Data Brief (2013) 132:1-8.

157. Rodriguez CJ, Daviglus ML, Swett K, Gonzalez HM, Gallo LC, WassertheilSmoller S, et al. Dyslipidemia patterns among Hispanics/Latinos of diverse background in the United States. Am J Med (2014) 127:1186-94. doi:10.1016/j.amjmed.2014.07.026

158. Centers for Disease Control and Prevention. Fast Facts and Fact Sheets: Current Cigarette Smoking among Adults in the United States. (2017). Available from: https://www.cdc.gov/tobacco/data_statistics/fact_sheets/ adult_data/cig_smoking/

159. Kaplan RC, Bangdiwala SI, Barnhart JM, Castañeda SF, Gellman MD, Lee DJ, et al. Smoking among U.S. Hispanic/Latino adults: the Hispanic Community Health Study/Study of Latinos. Am J Prev Med (2014) 46:496-506. doi:10.1016/j.amepre.2014.01.014

160. Liao Y, Tucker P, Okoro CA, Giles WH, Mokdad AH, Harris VB, et al. REACH 2010 surveillance for health status in minority communities - United States, 2001-2002. MMWR Surveill Summ (2004) 53:1-36.

161. Merchant G, Buelna C, Castañeda SF, Arredondo EM, Marshall SJ, Strizich G, et al. Accelerometer-measured sedentary time among Hispanic 
adults: results from the Hispanic Community Health Study/Study of Latinos (HCHS/SOL). Prev Med Rep (2015) 2:845-53. doi:10.1016/j.pmedr.2015.09.019

162. Siega-Riz AM, Sotres-Alvarez D, Ayala GX, Ginsberg M, Himes JH, Liu K, et al. Food-group and nutrient-density intakes by Hispanic and Latino backgrounds in the Hispanic Community Health Study/Study of Latinos. Am J Clin Nutr (2014) 99:1487-98. doi:10.3945/ajcn.113.082685

163. Mattei J, Sotres-Alvarez D, Daviglus ML, Gallo LC, Gellman M, Hu FB, et al. Diet quality and its association with cardiometabolic risk factors vary by Hispanic and Latino ethnic background in the Hispanic Community Health Study/Study of Latinos. J Nutr (2016) 146:2035-44. doi:10.3945/ jn.116.231209

164. Corsino L, Sotres-Alvarez D, Butera NM, Siega-Riz AM, Palacios C, Pérez CM, et al. Association of the DASH dietary pattern with insulin resistance and diabetes in U.S. Hispanic/Latino adults: results from the Hispanic Community Health Study/Study of Latinos (HCHS/SOL). BMJOpen Diabetes Res Care (2017) 5:e000402. doi:10.1136/bmjdrc-2017-000402

165. Bermúdez OI, Tucker KL. Trends in dietary patterns in Latin American populations. Cad Saude Publica (2003) 19(Suppl 1):S87-99. doi:10.1590/ S0102-311X2003000700010

166. Mattei J, Malik V, Wedick NM, Hu FB, Spiegelman D, Willett WC, et al. Reducing the global burden of type 2 diabetes by improving the quality of staple foods: the global nutrition and epidemiologic transition initiative. Global Health (2015) 11:23. doi:10.1186/s12992-015-0109-9

167. Zimmet P, Alberti KG, Shaw J. Global and societal implications of the diabetes epidemic. Nature (2001) 414:782-7. doi:10.1038/414782a

168. Carrera Boada CA, Martínez-Moreno JM. Pathophysiology of diabetes mellitus type 2: beyond the duo "insulin resistance-secretion deficit". Nutr Hosp (2013) 28(Suppl 2):78-87. doi:10.3305/nh.2013.28.sup2.6717

169. DeFronzo RA. Banting Lecture. From the triumvirate to the ominous octet: a new paradigm for the treatment of type 2 diabetes mellitus. Diabetes (2009) 58:773-95. doi:10.2337/db09-9028

170. Hotamisligil GS. Inflammation, metaflammation, and immunometabolic disorders. Nature (2017) 542:177-85. doi:10.1038/nature21363

171. Fonseca FA, Izar MC. High-sensitivity C-reactive protein and cardiovascular disease across countries and ethnicities. Clinics (Sao Paulo) (2016) 71:235-42. doi:10.6061/clinics/2016(04)11

172. Stern MP, Gaskill SP, Hazuda HP, Gardner LI, Haffner SM. Does obesity explain excess prevalence of diabetes among Mexican Americans? Results of the San Antonio Heart Study. Diabetologia (1983) 24:272-7. doi:10.1007/ BF00282712

173. Everhart JE, Pettitt DJ, Bennett PH, Knowler WC. Duration of obesity increases the incidence of NIDDM. Diabetes (1992) 41:235-40. doi:10.2337/ diabetes.41.2.235

174. Janssen A, Katzmarzyk PT, Ross R. Duration of obesity and metabolic health risk in American men and women. Ann Epidemiol (2004) 14:585-91. doi:10.1016/j.annepidem.2004.01.007

175. Attard SM, Herring AH, Howard AG, Gordon-Larsen P. Longitudinal trajectories of BMI and cardiovascular disease risk: the National Longitudinal Study of Adolescent Health. Obesity (2013) 21:2180-8. doi:10.1002/oby. 20569

176. López-Velázquez JA, Silva-Vidal KV, Ponciano-Rodríguez G, ChávezTapia NC, Arrese M, Uribe M, et al. The prevalence of nonalcoholic fatty liver disease in the Americas. Ann Hepatol (2014) 13:166-78.

177. Lazo M, Bilal U, Perez-Escamilla R. Epidemiology of NAFLD and type 2 diabetes: health disparities among persons of Hispanic origin. Curr Diab Rep (2015) 15:116. doi:10.1007/s11892-015-0674-6

178. Lorenzo C, Hazuda HP, Haffner SM. Insulin resistance and excess risk of diabetes in Mexican-Americans: the San Antonio Heart Study. J Clin Endocrinol Metab (2012) 97:793-9. doi:10.1210/jc.2011-2272

179. Hunt KJ, Williams K, Resendez RG, Hazuda HP, Haffner SM, Stern MP. All-cause and cardiovascular mortality among diabetic participants in the San Antonio Heart Study: evidence against the "Hispanic Paradox". Diabetes Care (2002) 25:1557-63. doi:10.2337/diacare.25.9.1557

180. Caballero AE, Bousquet-Santos K, Robles-Osorio L, Montagnani V, Soodini G, Porramatikul S, et al. Overweight Latino children and adolescents have marked endothelial dysfunction and subclinical vascular inflammation in association with excess body fat and insulin resistance. Diabetes Care (2008) 31:576-82. doi:10.2337/dc07-1540
181. Mendivil CO, Robles-Osorio L, Horton ES, Hamdy O, Caballero AE. Young Hispanics at risk of type 2 diabetes display endothelial activation, subclinical inflammation and alterations of coagulation and fibrinolysis. Diabetol Metab Syndr (2013) 5:37. doi:10.1186/1758-5996-5-37

182. Festa A, Hanley AJ, Tracy RP, D’Agostino R Jr, Haffner SM. Inflammation in the prediabetic state is related to increased insulin resistance rather than decreased insulin secretion. Circulation (2003) 108:1822-30. doi:10.1161/01. CIR.0000091339.70120.53

183. Ho RC, Davy KP, Hickey MS, Melby CL. Circulating tumor necrosis factor alpha is higher in non-obese, non-diabetic Mexican Americans compared to non-Hispanic white adults. Cytokine (2005) 30:14-21. doi:10.1016/j.cyto. 2004.10.015

184. Huffman FG, Gomez GP, Zarini GG. Metabolic syndrome and highsensitivity C-reactive protein in Cubans. Ethn Dis (2009) 19:115-20.

185. Reyes M, Gahagan S, Díaz E, Blanco E, Leiva L, Lera L, et al. Relationship of adiposity and insulin resistance mediated by inflammation in a group of overweight and obese Chilean adolescents. Nutr J (2011) 10:4. doi:10.1186/ 1475-2891-10-4

186. McFarlin BK, Johnson CA, Moreno JP, Foreyt JP. Mexican American children have differential elevation of metabolic biomarkers proportional to obesity status. J Pediatr Gastroenterol Nutr (2013) 57:718-21. doi:10.1097/ MPG.0b013e3182a6993d

187. Pérez CM, Ortiz AP, Fuentes-Mattei E, Velázquez-Torres G, Santiago D, Giovannetti K, et al. High prevalence of cardiometabolic risk factors in Hispanic adolescents: correlations with adipocytokines and markers of inflammation. J Immigr Minor Health (2014) 16:865-73. doi:10.1007/s10903013-9866-9

188. Weinstock RS, Drews KL, Caprio S, Leibel NI, McKay SV, Zeitler PS, et al. Metabolic syndrome is common and persistent in youth-onset type 2 diabetes: results from the TODAY clinical trial. Obesity (2015) 23:1357-61. doi:10.1002/oby.21120

189. Parrinello CM, Hua S, Carnethon MR, Gallo LC, Hudson BI, Goldberg RB, et al. Associations of hyperglycemia and insulin resistance with biomarkers of endothelial dysfunction in Hispanic/Latino youths: results from the Hispanic Community Children's Health Study/Study of Latino Youth (SOL Youth). J Diabetes Complications (2017) 31:836-42. doi:10.1016/j.jdiacomp. 2017.01.019

190. Kocarnik JM, Pendergrass SA, Carty CL, Pankow JS, Schumacher FR, Cheng I, et al. Multiancestral analysis of inflammation-related genetic variants and C-reactive protein in the population architecture using genomics and epidemiology study. Circ Cardiovasc Genet (2014) 7:178-88. doi:10.1161/CIRCGENETICS.113.000173

191. Kulick ER, Moon YP, Cheung K, Willey JZ, Sacco RL, Elkind MS. Racialethnic disparities in the association between risk factors and diabetes: the Northern Manhattan Study. Prev Med (2016) 83:31-6. doi:10.1016/j. ypmed.2015.11.023

192. Rosenbaum M, Fennoy I, Accacha S, Altshuler L, Carey DE, Holleran S, et al. Racial/ethnic differences in clinical and biochemical type 2 diabetes mellitus risk factors in children. Obesity (2013) 21:2081-90. doi:10.1002/oby. 20483

193. Avilés-Santa ML, Salinas K, Huet-Adams K, Raskin P. Insulin therapy, glycemic control, and cardiovascular risk factors in young Latin Americans with type 2 diabetes mellitus. J Investig Med (2006) 54:20-31. doi:10.2310/ 6650.2005 .05012

194. Mirza S, Hossain M, Mathews C, Martinez P, Pino P, Gay JL, et al. Type 2diabetes is associated with elevated levels of TNF-alpha, IL-6 and adiponectin and low levels of leptin in a population of Mexican Americans: a crosssectional study. Cytokine (2012) 57:136-42. doi:10.1016/j.cyto.2011.09.029

195. Kayser BD, Toledo-Corral CM, Alderete TL, Weigensberg MJ, Goran MI. Temporal relationships between adipocytokines and diabetes risk in Hispanic adolescents with obesity. Obesity (2015) 23:1479-85. doi:10.1002/ oby.21128

196. Pereira RI, Low Wang CC, Wolfe P, Havranek EP, Long CS, Bessesen DH. Associations of adiponectin with adiposity, insulin sensitivity, and diet in young, healthy, Mexican Americans and non-Latino white adults. Int J Environ Res Public Health (2015) 13:ijerh13010054. doi:10.3390/ijerph13010054

197. Hanley AJ, Bowden D, Wagenknecht LE, Balasubramanyam A, Langfeld C, Saad MF, et al. Associations of adiponectin with body fat distribution and 
insulin sensitivity in nondiabetic Hispanics and African-Americans. J Clin Endocrinol Metab (2007) 92:2665-71. doi:10.1210/jc.2006-2614

198. Koebnick C, Roberts CK, Shaibi GQ, Kelly LA, Lane CJ, Toledo-Corral CM, et al. Adiponectin and leptin are independently associated with insulin sensitivity, but not with insulin secretion or beta-cell function in overweight Hispanic adolescents. Horm Metab Res (2008) 40:708-12. doi:10.1055/s2008-1077097

199. Hanley AJ, Wagenknecht LE, Norris JM, Bergman R, Anderson A, Chen YI, et al. Adiponectin and the incidence of type 2 diabetes in Hispanics and African Americans: the IRAS Family Study. Diabetes Care (2011) 34:2231-6. doi:10.2337/dc11-0531

200. Gardener H, Crisby M, Sjoberg C, Hudson B, Goldberg R, Mendez AJ, et al. Serum adiponectin in relation to race-ethnicity and vascular risk factors in the Northern Manhattan Study. Metab Syndr Relat Disord (2013) 11:46-55. doi:10.1089/met.2012.0065

201. Arslanian S, El Ghormli L, Bacha F, Caprio S, Goland R, Haymond MW, et al. Adiponectin, insulin sensitivity, $\beta$-cell function, and racial/ethnic disparity in treatment failure rates in TODAY. Diabetes Care (2017) 40:85-93. doi:10.2337/dc16-0455

202. Butte NF, Cai G, Cole SA, Wilson TA, Fisher JO, Zakeri IF, et al. Metabolic and behavioral predictors of weight gain in Hispanic children: the Viva la Familia Study. Am J Clin Nutr (2007) 85:1478-85.

203. Mardones F, Arnaiz P, Pacheco P, Dominguez A, Villaroel L, Eriksson JG, et al. Associations of prenatal growth with metabolic syndrome, insulin resistance, and nutritional status in Chilean children. Biomed Res Int (2014) 2014:472017. doi:10.1155/2014/472017

204. Monteiro LJ, Norman JE, Rice GE, Illanes SE. Fetal programming and gestational diabetes mellitus. Placenta (2016) 30:S54-60. doi:10.1016/j. placenta.2015.11.015

205. Kanguru L, Bezawada N, Hussein J, Bell J. The burden of diabetes mellitus during pregnancy in low- and middle-income countries: a systematic review. Glob Health Action (2014) 7:23987. doi:10.3402/gha.v7.23987

206. Crume TL, Ogden L, Daniels S, Hamman RF, Norris JM, Dabelea D. The impact of in utero exposure to diabetes on childhood body mass index growth trajectories: the EPOCH Study. J Pediatr (2011) 158:941-6. doi:10.1016/j. jpeds.2010.12.007

207. Moore TR. Fetal exposure to gestational diabetes contributes to subsequent adult metabolic syndrome. Am J Obstet Gynecol (2010) 202:643-9. doi:10.1016/j.ajog.2010.02.059

208. Zhao P, Liu E, Qiao Y, Katzmarzyk PT, Chaput JP, Fogelholm M, et al. Maternal gestational diabetes and childhood obesity at age 9-11: results from a multinational study. Diabetologia (2016) 59:2339-48. doi:10.1007/ s00125-016-4062-9

209. Jiménez-Cruz A, Ortega-Cisneros A, Bacardí-Gascón M. Efecto de la diabetes gestacional sobre los indicadores de adiposidad en los primeros 18 años: Revisión sistemática. Nutr Hosp (2014) 29:397-401. doi:10.3305/nh. 2014.29.2.7042

210. Davis JN, Gunderson EP, Gyllenhammer LE, Goran MI. Impact of gestational diabetes mellitus on pubertal changes in adiposity and metabolic profiles in Latino offspring. J Pediatr (2013) 162:741-5. doi:10.1016/j.jpeds.2012.10.001

211. Egeland GM, Meltzer SJ. Following in mother's footsteps? Mother-daughter risks for insulin resistance and cardiovascular disease 15 years after gestational diabetes. Diabet Med (2010) 27:257-65. doi:10.1111/j.14645491.2010.02944.x

212. Page KA, Romero A, Buchanan TA, Xiang AH. Gestational diabetes mellitus, maternal obesity, and adiposity in offspring. J Pediatr (2014) 164:807-10. doi:10.1016/j.jpeds.2013.11.063

213. Silverman BL, Metzger BE, Cho NH, Loeb CA. Impaired glucose tolerance in adolescent offspring of diabetic mothers: relationship to fetal hyperinsulinism. Diabetes Care (1995) 18:611-7. doi:10.2337/diacare.18.5.611

214. Vaarasmaki M, Pouta A, Elliot P, Tapanainen P, Sovio U, Ruokonen A, et al. Adolescent manifestations of metabolic syndrome among children born to women with gestational diabetes in a general-population birth cohort. Am J Epidemiol (2009) 169:1209-15. doi:10.1093/aje/kwp020

215. The HAPO Study Cooperative Research Group. Hyperglycemia and adverse pregnancy outcomes. N Engl J Med (2008) 358:1991-2002. doi:10.1056/ NEJMoa0707943

216. Moreli JB, Corrêa-Silva S, Damasceno DC, Sinzato YK, Lorenzon-Ojea AR, Borbely AU, et al. Changes in the TNF-alpha/IL-10 ratio in hyperglycemia- associated pregnancies. Diabetes Res Clin Pract (2015) 107:362-9. doi:10.1016/j.diabres.2015.01.005

217. Sobrevia L, Salsoso R, Sáez T, Sanhueza C, Pardo F, Leiva A. Insulin therapy and fetoplacental vascular function in gestational diabetes mellitus. Exp Physiol (2015) 100:231-8. doi:10.1113/expphysiol.2014.082743

218. Salomón C, Westermeier F, Puebla C, Arroyo P, Guzmán-Gutiérrez E, Pardo F, et al. Gestational diabetes reduces adenosine transport in human placental microvascular endothelium, an effect reversed by insulin. PLoS One (2012) 7:e40578. doi:10.1371/journal.pone.0040578

219. Hara Cde C, França EL, Fagundes DL, de Queiroz AA, Rudge MV, HonorioFrança AC, et al. Characterization of natural killer cells and cytokines in maternal placenta and fetus of diabetic mothers. JImmunol Res (2016) 2016:7154524. doi:10.1155/2016/7154524

220. Gallardo JM, Gómez-López J, Medina-Bravo P, Juárez-Sánchez F, ContrerasRamos A, Galicia-Esquivel M, et al. Maternal obesity increases oxidative stress in the newborn. Obesity (2015) 23:1650-4. doi:10.1002/oby.21159

221. Olmos PR, Rigotti A, Busso D, Berkowitz L, Santos JL, Borzone GR, et al. Maternal hypertriglyceridemia: a link between maternal overweightobesity and macrosomia in gestational diabetes. Obesity (2014) 22:2156-63. doi:10.1002/oby.20816

222. Gelaleti RB, Damasceno DC, Lima PH, Salvadori DM, Calderon Ide M, Peraçoli JC, et al. Oxidative DNA damage in diabetic and mild gestational hyperglycemic pregnant women. Diabetol Metab Syndr (2015) 7:1. doi:10.1186/1758-5996-7-1

223. Moreli JB, Santos JH, Lorenzon-Ojea AR, Corrêa-Silva S, Fortunato RS, Rocha CR, et al. Hyperglycemia differentially affects maternal and fetal DNA integrity and DNA damage response. Int J Biol Sci (2016) 12:466-77. doi:10.7150/ijbs.12815

224. Uwaezuoke SN. Childhood diabetes mellitus and the "double burden of malnutrition": an emerging public health challenge in developing countries. J Diabetes Metab (2015) 6:1000597. doi:10.4172/2155-6156.1000597

225. Hales CN, Barker DJ. Type 2 (non-insulin-dependent) diabetes mellitus: the thrifty phenotype hypothesis. Diabetologia (1992) 35:595-601. doi:10.1007/ BF00400248

226. Silva AA, Santos CJ, Amigo H, Barbieri MA, Bustos P, Bettiol H, et al. Birth weight, current body mass index, and insulin sensitivity and secretion in young adults in two Latin American populations. Nutr Metab Cardiovasc Dis (2012) 22:533-9. doi:10.1016/j.numecd.2010.09.012

227. Gonzalez-Barranco J, Rios-Torres JM, Castillo-Martinez L, LopezAlvarenga JC, Aguilar-Salinas CA, Bouchard C, et al. Effect of malnutrition during the first year of life on adult plasma insulin and glucose tolerance. Metabolism (2003) 52:1005-11. doi:10.1016/S0026-0495(03)00151-3

228. Escaffi Fonseca MJ, Moreira Carrasco L, Rodríguez Osiac L, Pizarro Quevedo T, Cavada Chacón G, Villaroel del Pino L, et al. Efectos de la desnutrición calórico-proteica temprana en el estado nutricional y atributos del síndrome metabólico en una cohorte de adultos jóvenes. Nutr Hosp (2015) 32:1116-21. doi:10.3305/nh.2015.32.3.9395

229. Sapunar J, Bustos P, Sáez K, Muñoz S, Asenjo S. Efecto del estado nutricional neonatal en el riesgo de síndrome metabólico en niños obesos de 2 comunas de la región del Bío-Bío. Rev Med Chile (2014) 142:1523-9. doi:10.4067/ S0034-98872014001200005

230. Ramírez-Silva I, Rivera JA, Trejo-Valdivia B, Martorell R, Stein AD, Romieu I, et al. Breastfeeding status at age 3 months is associated with adiposity and cardiometabolic markers at age 4 years in Mexican children. J Nutr (2015) 145:1295-302. doi:10.3945/jn.114.198366

231. da Luz Santos CD, Clemente AP, Martins VJ, Albuquerque MP, Sawaya AL. Adolescents with mild stunting show alterations in glucose and insulin metabolism. J Nutr Metab (2010) 2010:943070. doi:10.1155/2010/943070

232. Ekoé JM, Shipp J. Malnutrition-related diabetes mellitus: myth or reality. In: Ekoé JM, Zimmet P, Williams R, editors. The Epidemiology of Diabetes Mellitus: An International Perspective. Chichester, New York: John Wiley (2001). p. 263-72.

233. Rao RH. The role of undernutrition in the pathogenesis of diabetes mellitus. Diabetes Care (1984) 7:595-601. doi:10.2337/diacare.7.6.595

234. Chattopadhyay PS, Gupta SK, Chattopadhyay R, Kundu PK, Chakraborti R. Malnutrition-related diabetes mellitus (MRDM), not diabetes-related malnutrition. Diabetes Care (1995) 18:276-7. doi:10.2337/diacare.18.2.276

235. Hoet JJ, Tripathy BB. Report of the international workshop on types of diabetes peculiar to the tropics. Diabetes Care (1996) 19:1014 
236. Rao RH, Yajnik CS. Commentary: time to rethink malnutrition and diabetes in the tropics. Diabetes Care (1996) 19:1014-7. doi:10.2337/diacare.19.9.1014

237. Lee CC, Watkins SM, Lorenzo C, Wagenknecht LE, Il'yasova D, Chen YD, et al. Branched-chain amino acids and insulin metabolism: the Insulin Resistance Atherosclerosis Study (IRAS). Diabetes Care (2016) 39:582-8. doi: $10.2337 / \mathrm{dc} 15-2284$

238. Umpiérrez GE, Smiley D, Kitabchi AE. Narrative review: ketosis-prone type 2 diabetes mellitus. Ann Intern Med (2006) 144:350-7. doi:10.7326/ 0003-4819-144-5-200603070-00011

239. Piñero-Piloña A, Litonjua P, Avilés-Santa L, Raskin P. Idiopathic type 1 diabetes in Dallas, Texas: a 5-year experience. Diabetes Care (2001) 24:1014-8. doi:10.2337/diacare.24.6.1014

240. Balasubramanyam A, Nalini R, Hampe CS, Maldonado M. Syndromes of ketosis-prone diabetes mellitus. Endocr Rev (2008) 29:292-302. doi:10.1210/ er.2007-0026

241. Feres MC, Fonseca FAH, Cintra FD, Mello-Fujita L, de Souza AL, De Martino MC, et al. An assessment of oxidized LDL in the lipid profiles of patients with obstructive sleep apnea and its association with both hypertension and dyslipidemia, and the impact of treatment with CPAP. Atherosclerosis (2015) 241:342-9. doi:10.1016/j.atherosclerosis.2015.05.008

242. Cintra F, Tufik S, de Paola A, Feres MC, Mello-Fujita L, Oliveira W, et al. Cardiovascular profile in patients with obstructive sleep apnea. Arq Bras Cardiol (2011) 96:293-9. doi:10.1590/S0066-782X2011005000030

243. Grandner MA, Chakravorty S, Perlis ML, Oliver L, Gurubhagavatula I. Habitual sleep duration associated with self-reported and objectively determined cardiometabolic risk factors. Sleep Med (2014) 15:42-50. doi:10.1016/ j.sleep.2013.09.012

244. Shechter A. Obstructive sleep apnea and energy balance regulation: a systematic review. Sleep Med Rev (2016) 34:59-69. doi:10.1016/j.smrv. 2016.07.001

245. Ip MS, Lam B, Ng MM, Lam WK, Tsang KW, Lam KS. Obstructive sleep apnea is independently associated with insulin resistance. Am J Respir Crit Care Med (2002) 165:670-6. doi:10.1164/ajrccm.165.5.2103001

246. Kendzerska T, Gershon AS, Hawker G, Tomlinson G, Leung RS. Obstructive sleep apnea and incident diabetes. A historical cohort study. Am J Respir Crit Care Med (2014) 190:218-25. doi:10.1164/rccm.201312-2209OC

247. Redline S, Sotres-Alvarez D, Loredo J, Hall M, Patel SR, Ramos A, et al. Sleep-disordered breathing in Hispanic/Latino individuals of diverse backgrounds: the Hispanic Community Health Study/Study of Latinos. Am J Respir Crit Care Med (2014) 189:335-44. doi:10.1164/rccm.201309-1735OC

248. Knutson KL, Wu D, Patel SR, Loredo JS, Redline S, Cai J, et al. Association between sleep timing, obesity, diabetes: the Hispanic Community Health Study/Study of Latinos (HCHS/SOL) cohort study. Sleep (2017) 40(4):zsx014. doi:10.1093/sleep/zsx014

249. Cespedes EM, Dudley KA, Sotres-Alvarez D, Zee PC, Daviglus ML, Shah NA, et al. Joint associations of insomnia and sleep duration with prevalent diabetes: the Hispanic Community Health Study/Study of Latinos (HCHS/SOL). J Diabetes (2016) 8:387-97. doi:10.1111/1753-0407.12308

250. Cade BE, Chen H, Stilp AM, Gleason KJ, Sofer T, Ancoli-Israel S, et al. Genetic associations with obstructive sleep apnea traits in Hispanic/Latino Americans. Am J Respir Crit Care Med (2016) 194:886-97. doi:10.1164/ rccm.201512-2431OC

251. Bakker JP, Weng J, Wang R, Redline S, Punjabi NM, Patel SR. Associations between obstructive sleep apnea, sleep duration, and abnormal fasting glucose. The multi-ethnic study of atherosclerosis. Am J Respir Crit Care Med (2015) 192:745-53. doi:10.1164/rccm.201502-0366OC

252. de la Monte SM. Type 3 diabetes is sporadic Alzheimer's disease: minireview. Eur Neuropsychopharmacol (2014) 24:1954-60. doi:10.1016/j. euroneuro.2014.06.008

253. Steen E, Terry BM, Rivera EJ, Cannon JL, Neely TR, Tavares R, et al. Impaired insulin and insulin-like growth factor expression and signaling mechanisms in Alzheimer's disease - is this type 3 diabetes? J Alzheimers Dis (2005) 7:63-80. doi:10.3233/JAD-2005-7107

254. Mayeda ER, Haan MN, Kanaya AM, Yaffe K, Nuehaus J. Type 2 diabetes and 10-year risk of dementia and cognitive impairment among older Mexican Americans. Diabetes Care (2013) 36:2600-6. doi:10.2337/dc12-2158

255. Mayeda ER, Haan MN, Yaffe K, Kanaya AM, Neuhaus J. Does type 2 diabetes increase rate of cognitive decline in older Mexican Americans? Alzheimer Dis Assoc Disord (2015) 29:206-12. doi:10.1097/WAD.0000000000000083
256. Tang WHW, Kitai T, Hazen SL. Gut microbiota in cardiovascular health and disease. Circ Res (2017) 120:1183-96. doi:10.1161/CIRCRESAHA.117. 309715

257. Lambeth SM, Carson T, Lowe J, Ramaraj T, Leff JW, Luo L, et al. Composition, diversity and abundance of gut microbiome in prediabetes and type 2 diabetes. J Diabetes Obes (2015) 2:1-7. doi:10.15436/2376-0949.15.031

258. Brunkwall L, Orho-Melander M. The gut microbiome as a target for prevention and treatment of hyperglycemia in type 2 diabetes: from current human evidence to future possibilities. Diabetologia (2017) 60:943-51. doi:10.1007/s00125-017-4278-3

259. García-Monzón C, Vargas-Castrillón J, Porrero JL, Alonso MT, Bonachia O, Castillo MJ, et al. Prevalence and risk factors for biopsy-proven non-alcoholic fatty liver disease and non-alcoholic steatohepatitis in a prospective cohort of adult patients with gallstones. Liver Int (2015) 35:1983-91. doi:10.1111/ liv. 12813

260. Martin EM, Styblo M, Fry RC. Genetic and epigenetic mechanisms underlying arsenic-associated diabetes mellitus: a perspective of the current evidence. Epigenomics (2017) 9:701-10. doi:10.2217/epi-2016-0097

261. Le Magueresse-Battistoni B, Vidal H, Naville D. Impact of in utero exposure to pollutants on metabolic health in adults. Med Sci (2016) 32:51-6. doi:10.1051/medsci/20163201009

262. Chevalier N, Fenichel P. Bisphenol A: targeting metabolic tissues. Rev Endocr Metab Disord (2015) 16:299-309. doi:10.1007/s11154-016-9333-8

263. Shearrer GE, O'Reilly GA, Belcher BR, Daniels MJ, Goran MI, SpruijtMetz D, et al. The impact of sugar sweetened beverage intake on hunger and satiety in minority adolescents. Appetite (2016) 97:43-8. doi:10.1016/ j.appet.2015.11.015

264. Below JE, Parra EJ. Genome-wide studies of type 2 diabetes and lipid traits in Hispanics. Curr Diab Rep (2016) 16:41. doi:10.1007/s11892-0160737-3

265. Lyssenko V, Lupi R, Marchetti P, Del Guerra S, Orho-Melander M, Almgren P, et al. Mechanisms by which common variants in the TCF7L2 gene increase risk of type 2 diabetes. JClin Invest (2007) 117:2155-63. doi:10.1172/JCI30706

266. Florez JC, Jablonski KA, Bayley N, Pollin TI, de Bakker PI, Shuldiner AR, et al. TCF7L2 polymorphisms and progression to diabetes in the diabetes prevention program. $N$ Engl J Med (2006) 355:241-50. doi:10.1056/ NEJMoa062418

267. Watanabe RM, Allayee H, Xiang AH, Trigo E, Hartiala J, Lawrence JM, et al. Transcription factor 7-like 2 (TCF7L2) is associated with gestational diabetes mellitus and interacts with adiposity to alter insulin secretion in Mexican Americans. Diabetes (2007) 56:1481-5. doi:10.2337/db06-1682

268. Martinez-Gomez LE, Cruz M, Martinez-Nava GA, Madrid-Marina V, Parra E, Garcia-Mena J, et al. A replication study of the IRS1, CAPN10, TCF7L2, and PPARG gene polymorphisms associated with type 2 diabetes in two different populations of Mexico. Ann Hum Genet (2011) 75:612-20. doi:10.1111/j.1469-1809.2011.00668.x

269. Palmer ND, Lehtinen AB, Langefeld CD, Campbell JK, Haffner SM, Norris JM, et al. Association of TCF7L2 gene polymorphisms with reduced acute insulin response in Hispanic Americans. JClin Endocrinol Metab (2008) 93:304-9. doi:10.1210/jc.2007-1225

270. Qi Q, Stilp AM, Sofer T, Moon JY, Hidalgo B, Szpiro AA, et al. Genetics of type 2 diabetes in U.S. Hispanic/Latino individuals: results from the Hispanic Community Health Study/Study of Latinos (HCHS/SOL). Diabetes (2017) 66:1419-25. doi:10.2337/db16-1150

271. Sousa AG, Marquezine GF, Lemos PA, Martinez E, Lopes N, Hueb WA, et al. TCF7L2 polymorphism rs7903146 is associated with coronary artery disease severity and mortality. PLoS One (2009) 4:e7697. doi:10.1371/journal. pone. 0007697

272. Muendlein A, Saely CH, Geller-Rhomberg S, Sonderegger G, Rein P, Winder T, et al. Single nucleotide polymorphisms of TCF7L2 are linked to diabetic coronary atherosclerosis. PLoS One (2011) 6:e17978. doi:10.1371/ journal.pone. 0017978

273. Choi HJ, Lee DH, Jeon HJ, Kim DS, Lee YH, Oh T. Transcription factor 7-like 2 (TCF7L2) gene polymorphism rs7903146 is associated with stroke in type 2 diabetes patients with long disease duration. Diabetes Res Clin Pract (2014) 103:e3-6. doi:10.1016/j.diabres.2013.12.051

274. Williams AL, Jacobs SB, Moreno-Macias H, Huerta-Chagoya A, Churchhouse C, Marquez-Luna C, et al. Sequence variants in SLC16A11 
are a common risk factor for type 2 diabetes in Mexico. Nature (2014) 506: 97-101. doi:10.1038/nature12828

275. Travers ME, Mackay DJ, Dekker Nitert M, Morris AP, Lindgren CM, Berry A, et al. Insights into the molecular mechanism for type 2 diabetes susceptibility at the KCNQ1 locus from temporal changes in imprinting status in human islets. Diabetes (2013) 62:987-92. doi:10.2337/db12-0819

276. Estrada K, Aukrust I, Bjorkhaug L, Burtt NP, Mercader JM, GarciaOrtiz $\mathrm{H}$, et al. Association of a low-frequency variant in HNF1A with type 2 diabetes in a Latino population. JAMA (2014) 311:2305-14. doi:10.1001/ jama.2014.6511

277. Palmer ND, Goodarzi MO, Langefeld CD, Wang N, Guo X, Taylor KD, et al. Genetic variants associated with quantitative glucose homeostasis traits translate to type 2 diabetes in Mexican Americans: the GUARDIAN (genetics underlying diabetes in Hispanics) consortium. Diabetes (2015) 64:1853-66. doi: $10.2337 / \mathrm{db} 14-0732$

278. Frigeri HR, Martins LT, Auwerter NC, dos Santos-Weiss ICR, Pedrosa FO, de Souza EM, et al. The polymorphism rs2268574 in glucokinase gene is associated with gestational diabetes mellitus. Clin Biochem (2014) 47: 499-500. doi:10.1016/j.clinbiochem.2014.01.024

279. Junior JP, Frigeri HR, Dos Santos-Weiss IC, Rego FG, Pitcheth G, Alberton D, et al. The MTNR1B gene polymorphism rs10830963 is associated with gestational diabetes in a Brazilian population. Gene (2015) 568:114-5. doi:10.1016/j.gene.2015.05.024

280. Blois SM, Gueuvoghlanian-Silva BY, Tirado-González I, Torloni MR, Freitag N, Mattar R, et al. Getting too sweet: galectin-1 dysregulation in gestational diabetes. Mol Hum Reprod (2014) 20:644-9. doi:10.1093/molehr/gau021

281. Gelaleti RB, Damasceno DC, Salvadori DM, Marcondes JP, Lima PH, Morceli G, et al. IRS-1 gene polymorphism and DNA damage in pregnant women with diabetes or mild gestational hyperglycemia. Diabetol Metab Syndr (2015) 7:30. doi:10.1186/s13098-015-0026-3

282. Sánchez Monroy V, González Díaz A, Lozano Trenado LM, Campos Peralta JM, Polo Soto S. Thr130lle polymorphism of HNF4A gene is associated with gestational diabetes mellitus in Mexican population. J Investig Med (2014) 62:632-4. doi:10.2310/JIM.0000000000000045

283. Guzmán-Flores JM, Escalante M, Sánchez-Corona J, García-Zapién AG, Cruz-Quevedo EG, Muñoz-Valle JF, et al. Association analysis between -308G/A and -238G/A TNF-alpha gene promoter polymorphisms and insulin resistance in Mexican women with gestational diabetes mellitus. J Investig Med (2013) 61:265-9. doi:10.2310/JIM.0b013e31827b98c9

284. Huerta-Chagoya A, Vázquez-Cárdenas P, Moreno-Macías H, Tapia-Maruri L, Rodríguez-Guillén R, López-Vite E, et al. Genetic determinants of gestational diabetes mellitus and related metabolic traits in Mexican women. PLoS One (2015) 10:e0126408. doi:10.1371/journal.pone.0126408

285. Reyes-López R, Pérez-Luque E, Malacara JM. Metabolic, hormonal characteristics and genetic variants of TCF7L2 associated with development of gestational diabetes mellitus in Mexican women. Diabetes Metab Res Rev (2014) 30:701-6. doi:10.1002/dmrr.2538

286. de Melo SF, Frigeri HR, dos Santos-Weiss IC, Réa RR, de Souza EM, Alberton D, et al. Polymorphisms in FTO and TCF7L2 genes of EuroBrazilian women with gestational diabetes. Biochemistry (2015) 48:1064-7. doi:10.1016/j.clinbiochem.2015.06.013

287. Kulkarni H, Kos MZ, Neary J, Dyer TD, Kent JW Jr, Goring HH, et al. Novel epigenetic determinants of type 2 diabetes in Mexican-American families. Hum Mol Genet (2015) 24:5330-44. doi:10.1093/hmg/ddv232

288. Mamtani M, Kulkarni H, Dyer TD, Göring HH, Neary JL, Cole SA, et al. Genome- and epigenome-wide association study of hypertriglyceridemic waist in Mexican American families. Clin Epigenetics (2016) 8:6. doi:10.1186/ s13148-016-0173-x

289. Barbieiri P, Nunes JC, Torres AG, Nishimura RY, Zuccolotto DC, Crivellenti LC, et al. Indices of dietary fat quality during midpregnancy is associated with gestational diabetes. Nutrition (2016) 32:656-61. doi:10.1016/j.nut.2015.12.002

290. Ramírez-Vélez R, Bustamante J, Czerniczyniec A, Aguilar de Plata AC, LoresArnaiz S. Effect of exercise training on eNOS expression, NO production and oxygen metabolism in human placenta. PLoS One (2013) 8:e80225. doi:10.1371/journal.pone.0080225

291. Ramírez-Vélez R, Aguilar de Plata AC, Escudero MM, Echeverry I, Ortega JG, Salazar B, et al. Influence of regular aerobic exercise on endothelium-dependent vasodilation and cardiorespiratory fitness in pregnant women.J Obstet Gynaecol Res (2011) 37:1601-8. doi:10.1111/j.14470756.2011.01582.x

292. Ramírez-Vélez R. Aerobic exercise training during pregnancy increases antioxidant status in nulliparous women: secondary data analysis of a controlled clinical trial. Endocrinol Nutr (2013) 60:279-81. doi:10.1016/j. endonu.2012.05.012

293. Cid M, González M. Potential benefits of physical activity during pregnancy for the reduction of gestational diabetes prevalence and oxidative stress. Early Hum Dev (2016) 94:57-62. doi:10.1016/j.earlhumdev.2016.01.007

294. Perales M, Santos-Lozano A, Ruiz JR, Lucia A, Barakat R. Benefits of aerobic or resistance training during pregnancy on maternal health and perinatal outcomes: a systematic review. Early Hum Dev (2016) 94:43-8. doi:10.1016/ j.earlhumdev.2016.01.004

295. Chasan-Taber L, Silveira M, Marcus BH, Braun B, Stanek E, Markenson G. Feasibility and efficacy of a physical activity intervention among pregnant women: the Behaviors Affecting Baby and You (B.A.B.Y.) Study. J Phys Act Health (2011) 8(Suppl 2):S228-38. doi:10.1123/jpah.8.s2.s228

296. Ehrlich SF, Hedderson MM, Quesenberry CP Jr, Feng J, Brown SD, Crites $\mathrm{Y}$, et al. Post-partum weight loss and glucose metabolism in women with gestational diabetes: the DEBI study. Diabet Med (2014) 31:862-7. doi:10.1111/ dme. 12425

297. Ferrara A, Hedderson MM, Brown SD, Albright CL, Enrlich SF, Tsai AL, et al. The comparative effectiveness of diabetes prevention strategies to reduce postpartum weight retention in women with gestational diabetes mellitus: the gestational diabetes' effects on moms (GEM) cluster randomized controlled trial. Diabetes Care (2016) 39:65-74. doi:10.2337/dc15-1254

298. Mendelson SG, McNeese-Smith D, Koniak-Griffin D, Nyamathi A, Lu MC. A community-based parish nurse intervention program for Mexican American women with gestational diabetes. J Obstet Gynecol Neonatal Nurs (2008) 37:415-25. doi:10.1111/j.1552-6909.2008.00262.x

299. Philis-Tsimikas A, Fortmann AL, Dharkar-Surber S, Euyoque JA, Ruiz M, Schultz J, et al. Dulce mothers: an intervention to reduce diabetes and cardiovascular risk in Latinas after gestational diabetes. Transl Behav Med (2014) 4:18-25. doi:10.1007/s13142-014-0253-4

300. Hawkins M, Hosker M, Marcus BH, Rosal MC, Braun B, Stanek EJ, et al. A pregnancy lifestyle intervention to prevent gestational diabetes risk factors in overweight Hispanic women: a feasibility randomized controlled trial. Diabet Med (2015) 32:108-15. doi:10.1111/dme.12601

301. Athavale P, Thomas M, Delgadillo-Duenas AT, Leong K, Najmabadi A, Harleman E, et al. Linking high risk postpartum women with a technology enabled health coaching program to reduce diabetes risk and improve wellbeing: program description, case studies, and recommendations for community health coaching programs. J Diabetes Res (2016) 2016:4353956. doi:10.1155/2016/4353956

302. Chasan-Taber L, Marcus BH, Rosal MC, Tucker KL, Hartnan SJ, Pekow P, et al. Estudio Parto: postpartum diabetes prevention program for Hispanic women with abnormal glucose tolerance in pregnancy: a randomized controlled trial - study protocol. BMC Pregnancy Childbirth (2014) 14:100. doi:10.1186/1471-2393-14-100

303. Haemer MA, Grow HM, Fernandez C, Lukasiewicz GJ, Rhodes ET, Shaffer LA, et al. Addressing prediabetes in childhood obesity treatment programs: support from research and current practice. Child Obes (2014) 10:292-303. doi:10.1089/chi.2013.0158

304. Branscum P, Sharma M. A systematic analysis of childhood obesity prevention interventions targeting Hispanic children: lessons learned from the previous decade. Obes Rev (2011) 12:e151-8. doi:10.1111/j.1467-789X. 2010.00809.x

305. Brown T, Summerbell C. Systematic review of school-based interventions that focus on changing dietary intake and physical activity levels to prevent childhood obesity: an update to the obesity guidance produced by the National Institute for Health and Clinical Excellence. Obes Rev (2009) 10:110-41. doi:10.1111/j.1467-789X.2008.00515.x

306. Dietz WH, Gortmaker SL. Preventing obesity in children and adolescents. Annu Rev Public Health (2001) 22:337-53. doi:10.1146/annurev.publhealth. 22.1.337

307. Loveman E, Al-Khudairy L, Johnson RE, Robertson W, Colquitt JL, Mead EL, et al. Parent-only interventions for childhood overweight or obesity in children aged 5 to 11 years. Cochrane Database Syst Rev (2015) 12:CD012008. doi:10.1002/14651858.CD012008 
308. Pérez-Morales ME, Bacardí-Gascón M, Jiménez-Cruz A. Childhood overweight and obesity prevention interventions among Hispanic children in the United States: systematic review. Nutr Hosp (2012) 27:1415-21. doi:10.3305/ nh.2012.27.5.5973

309. Stice E, Shaw H, Marti CN. A meta-analytic review of obesity prevention programs for children and adolescents: the skinny on interventions that work. Psychol Bull (2006) 132:667-91. doi:10.1037/0033-2909.132.5.667

310. Wang Y, Cai L, Wu Y, Wilson RF, Weston C, Fawole O, et al. What childhood obesity prevention programmes work? A systematic review and metaanalysis. Obes Rev (2015) 16:547-65. doi:10.1111/obr.12277

311. Whitlock EP, O'Connor EA, Williams SB, Beil TL, Lutz KW (Oregon Evidence-Based Practice Center, Center for Health Research, Portland, OR). Effectiveness of Primary Care Interventions for Weight Management in Children and Adolescents: An Updated, Targeted Systematic Review for the USPSTF. Rockville, MD: Agency for Healthcare Research and Quality (US) (2010). $168 \mathrm{p}$.

312. Whitlock EP, O'Connor EA, Williams SB, Beil TL, Lutz KW. Effectiveness of weight management interventions in children: a targeted systematic review for the USPSTF. Pediatrics (2010) 125:e396-418. doi:10.1542/peds.20091955

313. Kelly LA, Lane CJ, Weigensberg MJ, Toledo-Corral CM, Goran MI. Pubertal changes of insulin sensitivity, acute insulin response, and $\beta$-cell function in overweight Latino youth. J Pediatr (2011) 158:442-6. doi:10.1016/j.jpeds. 2010.08.046

314. Marshall WA, Tanner JM. Variations in pattern of pubertal changes in girls. Arch Dis Child (1969) 44:291-303. doi:10.1136/adc.44.235.291

315. Marshall WA, Tanner JM. Variations in the pattern of pubertal changes in boys. Arch Dis Child (1970) 45:13-23. doi:10.1136/adc.45.239.13

316. Wells JC, Cole TJ. Height, adiposity and hormonal cardiovascular risk markers in childhood: how to partition the associations? Int J Obes (2014) 38:930-5. doi:10.1038/ijo.2014.24

317. Yajnik CS. Nutrition, growth, and body size in relation to insulin resistance and type 2 diabetes. Curr Diab Rep (2003) 3:108-14. doi:10.1007/ s11892-003-0033-x

318. Berkowitz RI, Wadden TA, Gehrman CA, Bishop-Gilyard CT, Moore RH, Womble LG, et al. Meal replacements in the treatment of adolescent obesity: a randomized controlled trial. Obesity (2011) 19:1193-9. doi:10.1038/oby. 2010.288

319. Berkowitz RI, Wadden TA, Tershakovec AM, Cronquist JL. Behavior therapy and sibutramine for the treatment of adolescent obesity: a randomized controlled trial. JAMA (2003) 289:1805-12. doi:10.1001/jama.289.14.1805

320. Fox CK, Kaizer AM, Rudser KD, Nathan BM, Gross AC, Sunni M, et al. Meal replacements followed by topiramate for the treatment of adolescent severe obesity: a pilot randomized controlled trial. Obesity (2016) 24:2553-61. doi:10.1002/oby.21633

321. Jelalian E, Lloyd-Richardson EE, Mehlenbeck RS, Hart CN, Flynn-O’Brien K, Kaplan J, et al. Behavioral weight control treatment with supervised exercise or peer-enhanced adventure for overweight adolescents. J Pediatr (2010) 157:923-8. doi:10.1016/j.jpeds.2010.05.047

322. Lloyd-Richardson EE, Jelalian E, Sato AF, Hart CN, Mehlenbeck R, Wing RR. Two-year follow-up of an adolescent behavioral weight control intervention. Pediatrics (2012) 130:e281-8. doi:10.1542/peds.2011-3283

323. Parillo M, Licenziati MR, Vacca M, De Marco D, Iannuzzi A. Metabolic changes after a hypocaloric, low-glycemic-index diet in obese children. J Endocrinol Invest (2012) 35:629-33. doi:10.3275/7909

324. Reinehr T, Kiess W, Kapellen T, Andler W. Insulin sensitivity among obese children and adolescents, according to degree of weight loss. Pediatrics (2004) 114:1569-73. doi:10.1542/peds.2003-0649-F

325. Ventura E, Davis J, Byrd-Williams C, Alexander K, McClain A, Lane CJ, et al. Reduction in risk factors for type 2 diabetes mellitus in response to a lowsugar, high-fiber dietary intervention in overweight Latino adolescents. Arch Pediatr Adolesc Med (2009) 163:320-7. doi:10.1001/archpediatrics.2009.11

326. Holub CK, Elder JP, Arredondo EM, Barquera S, Eisenberg CM, Sánchez Romero LM, et al. Obesity control in Latin American and U.S. Latinos: a systematic review. Am J Prev Med (2013) 44:529-37. doi:10.1016/ j.amepre.2013.01.023

327. Lindberg NM, Stevens VJ. Review: weight-loss interventions with Hispanic populations. Ethn Dis (2007) 17:397-402.
328. Lobelo F, Garcia de Quevedo I, Holub CK, Nagle BJ, Arredondo EM, Barquera S, et al. School-based programs aimed at the prevention and treatment of obesity: evidence-based interventions for youth in Latin America. J Sch Health (2013) 83:668-77. doi:10.1111/josh.12080

329. Nagle BJ, Holub CK, Barquera S, Sánchez-Romero LM, Eisenberg CM, Rivera-Dommarco JA, et al. Interventions for the treatment of obesity among children and adolescents in Latin America: a systematic review. Salud Publica Mex (2013) 55(Suppl 3):434-40. doi:10.21149/spm.v55s3.5145

330. Eisenberg CM, Sánchez-Romero LM, Rivera-Dommarco JA, Holub CK, Arredondo EM, Elder JP, et al. Interventions to increase physical activity and healthy eating among overweight and obese children in Mexico. Salud Publica Mex (2013) 55(Suppl 3):441-6. doi:10.21149/spm.v55s3.5146

331. Ayala GX, Ibarra L, Binggeli-Vallarta A, Moody J, McKenzie TL, Angulo J, et al. Our choice/Nuestra opción: the Imperial County, California, childhood obesity research demonstration study (CA-CORD). Child Obes (2015) 11:37-47. doi:10.1089/chi.2014.0080

332. Dooyema CA, Belay B, Foltz JL, Williams N, Blanck HM. The childhood obesity research demonstration project: a comprehensive community approach to reduce childhood obesity. Child Obes (2013) 9:454-9. doi:10.1089/ chi.2013.0060

333. O'Connor DP, Lee RE, Mehta P, Thompson D, Bhargava A, Carlson C, et al. Childhood obesity research demonstration project: cross-site evaluation methods. Child Obes (2015) 11:92-103. doi:10.1089/chi.2014.0061

334. Williams N, Dooyema CA, Foltz JL, Belay B, Blanck HM. The childhood obesity research demonstration project: a team approach for supporting a multisite, multisector intervention. Child Obes (2015) 1:104-8. doi:10.1089/ chi.2014.0063

335. Epstein LH, Gordy CC, Raynor HA, Beddome M, Kilanowski CK, Paluch R. Increasing fruit and vegetable intake and decreasing fat and sugar intake in families at risk for childhood obesity. Obes Res (2001) 9:171-8. doi:10.1038/ oby.2001.18

336. American Diabetes Association. Preventing Type 2 Diabetes [Internet]. Arlington, VA: American Diabetes Association (2014). Available from: http://www.diabetes.org/living-with-diabetes/parents-and-kids/childrenand-type-2/preventing-type-2-in-children.html

337. Gow ML, Garnett SP, Baur LA, Lister NB. The effectiveness of different diet strategies to reduce type 2 diabetes risk in youth. Nutrients (2016) 8:486 doi:10.3390/nu8080486

338. Fajcsak Z, Gabor A, Kovacs V, Martos E. The effects of 6-week low glycemic load diet based on low glycemic index foods in overweight/obese children pilot study. JAm Coll Nutr (2008) 27:12-21. doi:10.1080/07315724. 2008.10719670

339. Gellar L, Nansel TR. High and low glycemic index mixed meals and blood glucose in youth with type 2 diabetes or impaired glucose tolerance. J Pediatr (2009) 154:455-8. doi:10.1016/j.jpeds.2008.09.040

340. Iannuzzi A, Licenziati MR, Vacca M, De Marco D, Cinquegrana G, Laccetti $\mathrm{M}$, et al. Comparison of two diets of varying glycemic index on carotid subclinical atherosclerosis in obese children. Heart Vessels (2009) 24:419-24. doi:10.1007/s00380-008-1138-6

341. Krebs NF, Gao D, Gralla J, Collins JS, Johnson SL. Efficacy and safety of a high protein, low carbohydrate diet for weight loss in severely obese adolescents. J Pediatr (2010) 157:252-8. doi:10.1016/j.jpeds.2010.02.010

342. Ebbeling CB, Leidig MM, Sinclair KB, Hangen JP, Ludwig DS. A reducedglycemic load diet in the treatment of adolescent obesity. Arch Pediatr Adolesc Med (2003) 157:773-9. doi:10.1001/archpedi.157.8.773

343. Boule NG, Haddad E, Kenny GP, Wells GA, Sigal RJ. Effects of exercise on glycemic control and body mass in type 2 diabetes mellitus: a metaanalysis of controlled clinical trials. JAMA (2001) 286:1218-27. doi:10.1001/ jama.286.10.1218

344. Bunt JC, Salbe AD, Harper IT, Hanson RL, Tataranni PA. Weight, adiposity, and physical activity as determinants of an insulin sensitivity index in Pima Indian children. Diabetes Care (2003) 26:2524-30. doi:10.2337/diacare. 26.9.2524

345. Duncan GE. The "fit but fat" concept revisited: population-based estimates using NHANES. Int J Behav Nutr Phys Act (2010) 7:47. doi:10.1186/14795868-7-47

346. Lee S, Kuk JL, Davidson LE, Hudson R, Kilpatrick K, Graham TE, et al. Exercise without weight loss is an effective strategy for obesity reduction 
in obese individuals with and without type 2 diabetes. J Appl Physiol (2005) 99:1220-5. doi:10.1152/japplphysiol.00053.2005

347. Macias-Cervantes MH, Malacara JM, Garay-Sevilla ME, Díaz-Cisneros FJ. Effect of recreational physical activity on insulin levels in Mexican/ Hispanic children. Eur J Pediatr (2009) 168:1195-202. doi:10.1007/s00431008-0907-7

348. Ross R, Janssen I, Dawson J, Kungl AM, Kuk JL, Wong SL, et al. Exerciseinduced reduction in obesity and insulin resistance in women: a randomized controlled trial. Obes Res (2004) 12:789-98. doi:10.1038/oby.2004.95

349. Sugiura H, Sugiura H, Kajima K, Mirbod SM, Iwata H, Matsuoka T. Effects of long-term moderate exercise and increase in number of daily steps on serum lipids in women: randomised controlled trial [ISRCTN21921919]. BMC Womens Health (2002) 2:3. doi:10.1186/1472-6874-2-3

350. Aires L, Silva G, Martins C, Marques E, Lagoa MJ, Ribeiro JC, et al. Exercise intervention and cardiovascular risk factors in obese children. Comparison between obese youngsters taking part in a physical activity school-based programme with and without individualised diet counselling: the ACORDA project. Ann Hum Biol (2016) 43:183-90. doi:10.3109/03014460.2015. 1059889

351. Dobbins M, Husson H, DeCorby K, LaRocca RL. School-based physical activity programs for promoting physical activity and fitness in children and adolescents aged 6 to 18. Cochrane Database Syst Rev (2013) 2:CD007651. doi:10.1002/14651858.CD007651.pub2

352. Janssen I, Leblanc AG. Systematic review of the health benefits of physical activity and fitness in school-aged children and youth. Int J Behav Nutr Phys Act (2010) 7:40. doi:10.1186/1479-5868-7-40

353. Neumark-Sztainer DR, Friend SE, Flattum CF, Hannan PJ, Story MT, Bauer KW, et al. New moves - preventing weight-related problems in adolescent girls: a group-randomized study. Am J Prev Med (2010) 39:421-32. doi:10.1016/j.amepre.2010.07.017

354. Grey M, Jaser SS, Holl MG, Jefferson V, Dziura J, Northrup V. A multifaceted school-based intervention to reduce risk for type 2 diabetes in at-risk youth. Prev Med (2009) 49:122-8. doi:10.1016/j.ypmed.2009.07.014

355. Treviño RP, Yin Z, Hernandez A, Hale DE, Garcia OA, Mobley C. Impact of the Bienestar school-based diabetes mellitus prevention program on fasting capillary glucose levels: a randomized controlled trial. Arch Pediatr Adolesc Med (2004) 158:911-7. doi:10.1001/archpedi.158.9.911

356. Rosenbaum M, Nonas C, Weil R, Horlick M, Fennoy I, Vargas I, et al. Schoolbased intervention acutely improves insulin sensitivity and decreases inflammatory markers and body fatness in junior high school students. J Clin Endocrinol Metab (2007) 92:504-8. doi:10.1210/jc.2006-1516

357. Johnston CA, Moreno JP, Foreyt JP. Cardiovascular effects of intensive lifestyle intervention in type 2 diabetes. Curr Atheroscler Rep (2014) 16:457. doi:10.1007/s11883-014-0457-6

358. Foster GD, Linder B, Baranowski T, Cooper DM, Goldberg L, Harrell JS, et al. A school-based intervention for diabetes risk reduction. $N$ Engl J Med (2010) 363:443-53. doi:10.1056/NEJMoa1001933

359. Willi SM, Hirst K, Jago R, Buse J, Kaufman F, El Ghormli L, et al. Cardiovascular risk factors in multi-ethnic middle school students: the HEALTHY primary prevention trial. Pediatr Obes (2012) 7:230-9. doi:10.1111/j.20476310.2011.00042.x

360. Silva HJ, Andersen LB, Lofrano-Prado MC, Barros MV, Freitas IF Jr, Hill J, et al. Improvements on cardiovascular diseases risk factors in obese adolescents: a randomized exercise intervention study. J Phys Act Health (2015) 12:553-60. doi:10.1123/jpah.2013-0199

361. Ryder JR, Vega-Lopez S, Ortega R, Konopken Y, Shaibi GQ. Lifestyle intervention improves lipoprotein particle size and distribution without weight loss in obese Latino adolescents. Pediatr Obes (2013) 8:e59-63. doi:10.1111/j.2047-6310.2013.00162.x

362. Shaibi GQ, Konopken Y, Hoppin E, Keller CS, Ortega R, Castro FG. Effects of a culturally grounded community-based diabetes prevention program for obese Latino adolescents. Diabetes Educ (2012) 38:504-12. doi:10.1177/0145721712446635

363. Velázquez-López L, Rico Ramos JM, Torres Tamayo M, Medina Bravo P, Toca Porraz LE, Escobedo de la Peña J. Impacto de la educación nutricional sobre alteraciones metabólicas en niños y adolescentes con obesidad. Endocrinol Nutr (2009) 56:441-6. doi:10.1016/S1575-0922(09)73311-X

364. Knowler WC, Barrett-Connor E, Fowler SE, Hamman RF, Lachin JM, Walker EA, et al. Reduction in the incidence of type 2 diabetes with lifestyle intervention or metformin. N Engl J Med (2002) 346:393-403. doi:10.1056/ NEJMoa012512

365. Rubin RR, Fujimoto WY, Marrero DG, Brenneman T, Charleston JB, Edelstein SL, et al. The diabetes prevention program: recruitment methods and results. Control Clin Trials (2002) 23:157-71. doi:10.1016/ S0197-2456(01)00184-2

366. West DS, Prewitt TE, Bursac Z, Felix HC. Weight loss of black, white, and Hispanic men and women in the diabetes prevention program. Obesity (2008) 16:1413-20. doi:10.1038/oby.2008.224

367. O’Brien MJ, Perez A, Alos VA, Whitaker RC, Ciolino JD, Mohr DC, et al. The feasibility, acceptability, and preliminary effectiveness of a promotoraled diabetes prevention program (PL-DPP) in Latinas: a pilot study. Diabetes Educ (2015) 41:485-94. doi:10.1177/0145721715586576

368. Ockene IS, Tellez TL, Rosal MC, Reed GW, Mordes J, Merriam PA, et al. Outcomes of a Latino community-based intervention for the prevention of diabetes: the Lawrence Latino diabetes prevention project. Am J Public Health (2012) 102:336-42. doi:10.2105/AJPH.2011.300357

369. Ruggiero L, Oros S, Choi YK. Community-based translation of the diabetes prevention program's lifestyle intervention in an underserved Latino population. Diabetes Educ (2011) 37:564-72. doi:10.1177/0145721711411107

370. Van Name MA, Camp AW, Magenheimer EA, Li F, Dziura JD, Montosa A, et al. Effective translation of an intensive lifestyle intervention for Hispanic women with prediabetes in a community health center setting. Diabetes Care (2016) 39:525-31. doi:10.2337/dc15-1899

371. Vincent D, McEwen MM, Hepworth JT, Stump CS. The effects of a community-based, culturally tailored diabetes prevention intervention for high-risk adults of Mexican descent. Diabetes Educ (2014) 40:202-13. doi:10.1177/0145721714521020

372. West-Pollak A, Then EP, Podesta C, Hedelt A, Perry ML, Izarnotegui WV, et al. Impact of a novel community-based lifestyle intervention program on type 2 diabetes and cardiovascular risk in a resource-poor setting in the Dominican Republic. Int Health (2014) 6:118-24. doi:10.1093/inthealth/iht039

373. Fain JA. The diabetes prevention program: replicating/translating the results. Diabetes Educ (2009) 35:179. doi:10.1177/01457217090350020301

374. Giese KK, Cook PF. Reducing obesity among employees of a manufacturing plant: translating the diabetes prevention program to the workplace. Workplace Health Saf (2014) 62:136-41. doi:10.3928/21650799-20140305-02

375. Jackson L. Translating the diabetes prevention program into practice: a review of community interventions. Diabetes Educ (2009) 35:309-20. doi:10.1177/0145721708330153

376. Krame MK, Kriska AM, Venditti EM, Miller RG, Brooks MM, Burke LE, et al. Translating the diabetes prevention program: a comprehensive model for prevention training and program delivery. Am J Prev Med (2009) 37:505-11. doi:10.1016/j.amepre.2009.07.020

377. Seidel MC, Powell RO, Zgibor JC, Siminerio LM, Piatt GA. Translating the diabetes prevention program into an urban medically underserved community: a nonrandomized prospective intervention study. Diabetes Care (2008) 31:684-9. doi:10.2337/dc07-1869

378. Whittemor R, Melkus G, Wagner J, Dziura J, Northrup V, Grey M. Translating the diabetes prevention program to primary care: a pilot study. Nurs Res (2009) 58:2-12. doi:10.1097/NNR.0b013e31818fcef3

379. Ali MK, Echouffo-Tcheugui J, Williamson DF. How effective were lifestyle interventions in real-world settings that were modeled on the diabetes prevention program? Health Aff (2012) 31:67-75. doi:10.1377/hlthaff.2011.1009

380. McCurley JL, Gutierrez AP, Gallo LC. Diabetes prevention in U.S. Hispanic adults: a systematic review of culturally tailored interventions. Am J Prev Med (2017) 52:519-29. doi:10.1016/j.amepre.2016.10.028

381. Rosas LG, Lv N, Xiao L, Lewis MA, Zavella P, Kramer MK, et al. Evaluation of a culturally-adapted lifestyle intervention to treat elevated cardiometabolic risk of Latino adults in primary care (Vida Sana): a randomized controlled trial. Contemp Clin Trials (2016) 48:30-40. doi:10.1016/j.cct.2016.03.003

382. Colón-Ramos U, Thompson FE, Yaroch AL, Moser RP, McNeel TS, Dodd KW, et al. Differences in fruit and vegetable intake among Hispanic subgroups in California: results from the 2005 California Health Interview Survey. J Am Diet Assoc (2009) 109:1878-85. doi:10.1016/j.jada.2009.08.015

383. Smith TM, Colón-Ramos U, Pinard CA, Yaroch AL. Household food insecurity as a determinant of overweight and obesity among low-income Hispanic subgroups: data from the 2011-2012 California Health Interview Survey. Appetite (2016) 97:37-42. doi:10.1016/j.appet.2015.11.009 
384. Heisler M, Kaselitz E, Rana GK, Piette JD. Diabetes prevention interventions in Latin American countries: a scoping review. Curr Diab Rep (2016) 16:80. doi:10.1007/s11892-016-0778-7

385. Svetkey LP, Simons-Morton D, Vollmer WM, Appel LJ, Conlin PR, Ryan DH, et al. Effects of dietary patterns on blood pressure: subgroup analysis of the dietary approaches to stop hypertension (DASH) randomized clinical trial. Arch Intern Med (1999) 159:285-93. doi:10.1001/archinte.159.3.285

386. Lima ST, da Silva Nalin de Souza B, Franca AK, Salgado Filho N, Sichieri R. Dietary approach to hypertension based on low glycaemic index and principles of DASH (dietary approaches to stop hypertension): a randomised trial in a primary care service. Br J Nutr (2013) 110:1472-9. doi:10.1017/ S0007114513000718

387. Sartorelli DS, Sciarra EC, Franco LJ, Cardoso MA. Beneficial effects of shortterm nutritional counselling at the primary health-care level among Brazilian adults. Public Health Nutr (2005) 8:820-5. doi:10.1079/PHN2005737

388. Assunção MC, Gigante DP, Cardoso MA, Sartorelli DS, Santos IS. Randomized, controlled trial promotes physical activity and reduces consumption of sweets and sodium among overweight and obese adults. Nutr Res (2010) 30:541-9. doi:10.1016/j.nutres.2010.07.006

389. Lindgärde F, Ahrén B. Improved metabolic risk markers following two 6-month physical activity programs among socioeconomic marginalized women of Native American ancestry in Lima, Peru. Diabetes Care (2007) 30:2230-2. doi:10.2337/dc06-2633

390. Pimentel GD, Portero-McLellan KC, Oliveira EP, Spada AP, Oshiiwa M, Zemdegs JC, et al. Long-term nutrition education reduces several risk factors for type 2 diabetes mellitus in Brazilians with impaired glucose tolerance. Nutr Res (2010) 30:186-90. doi:10.1016/j.nutres.2010.03.003

391. Buchanan TA, Xiang AH, Peters RK, Kjos SL, Marroquin A, Goico J, et al. Preservation of pancreatic $\beta$-cell function and prevention of type 2 diabetes by pharmacological treatment of insulin resistance in high-risk Hispanic women. Diabetes (2002) 51:2796-803. doi:10.2337/diabetes.51.9.2796

392. Xiang AH, Peters RK, Kjos SL, Marroquin A, Goico J, Ochoa C, et al. Effect of pioglitazone on pancreatic $\beta$-cell function and diabetes risk in Hispanic women with prior gestational diabetes. Diabetes (2006) 55:517-22. doi:10.2337/diabetes.55.02.06.db05-1066

393. Boyko EJ, Gerstein HC, Mohan V, Yusuf S, Sheridan P, Anand S, et al. Effects of ethnicity on diabetes incidence and prevention: results of the diabetes reduction assessment with ramipril and rosiglitazone medication (DREAM) trial. Diabet Med (2010) 27:1226-32. doi:10.1111/j.1464-5491. 2010.03064.x

394. DeFronzo RA, Tripathy D, Schwenke DC, Banerji MA, Bray GA, Buchanan TA, et al. Pioglitazone for diabetes prevention in impaired glucose tolerance. N Engl J Med (2011) 364:1104-15. doi:10.1056/NEJMoa1010949

395. O’Brien MJ, Perez A, Scanlan AB, Alos VA, Whitaker RC, Foster GD, et al. PREVENT-DM comparative effective trial of lifestyle intervention and metformin. Am J Prev Med (2017) 52:788-97. doi:10.1016/j.amepre.2017.01.008

396. Lewin AJ, Kereiakes DJ, Chrysant SG, Izzo JL, Oparil S, Lee J, et al. Triple-combination treatment with olmesartan medoxomil/amlodipine/ hydrochlorothiazide in Hispanic/Latino patients with hypertension: the TRINITY study. Ethn Dis (2014) 24:41-7.

397. Cooper-DeHoff RM, Aranda JM, Gaxiola E, Cangiano JL, Garcia-Barreto D, Conti R, et al. Blood pressure control and cardiovascular outcomes in highrisk Hispanic patients - findings from the INternational VErapamil SR/ Trandolapril STudy (INVEST). Am Heart J (2006) 151:1072-9. doi:10.1016/ j.ahj.2005.05.024

398. Cooper-DeHoff RM, Cohen JD, Bakris GL, Messerli FH, Erdine S, Hewkin AC, et al. Predictors of development of diabetes mellitus in patients with coronary artery disease taking antihypertensive medications (findings from the International Verapamil SR-Trandolapril Study [INVEST]). Am J Cardiol (2006) 98:890-4. doi:10.1016/j.amjcard.2006.04.030

399. Margolis KL, Piller LB, Ford CE, Henriquez MA, Cushman WC, Einhorn PT, et al. Blood pressure control in Hispanics in the antihypertensive and lipid-lowering treatment to prevent heart attack trial. Hypertension (2007) 50:854-61. doi:10.1161/HYPERTENSIONAHA.107.092650

400. Wright JT, Lacourciere Y, Samuel R, Zappe D, Purkayastha D, Black HR. 24-hr ambulatory blood pressure response to combination valsartan/hydrochlorothiazide and amlodipine/hydrochlorothiazide in stage 2 hypertension by ethnicity: the EVALUATE study. J Clin Hypertens (2010) 12:833-40. doi:10.1111/j.1751-7176.2010.00372.x
401. Yusuf S, Gerstein H, Hoogwerf B, Pogue J, Bosch J, Wolffenbuttel BHR, et al. Ramipril and the development of diabetes. JAMA (2001) 286:1882-5. doi:10.1001/jama.286.15.1882

402. Elliott WJ, Meyer PM. Incident diabetes in clinical trials of antihypertensive drugs: a network meta-analysis. Lancet (2007) 369:201-7. doi:10.1016/S01406736(07)60108-1

403. Cooper-DeHoff RM, Zhou Q, Gaxiola E, Cangiano JL, Garcia-Barreto D, Handberg E, et al. Influence of Hispanic ethnicity on blood pressure control and cardiovascular outcomes in women with CAD and hypertension: findings from INVEST. J Womens Health (2007) 16:632-40. doi:10.1089/ jwh.2006.0086

404. Punzi H, Lewin A, Lukic T, Goodin T, Chen W. Efficacy and safety of nebivolol in Hispanics with stage I-II hypertension: a randomized placebocontrolled trial. Ther Adv Cardiovasc Dis (2010) 4:349-57. doi:10.1177/ 1753944710387629

405. Aranda JM Jr, Calderon R, Aranda JM Sr. Clinical characteristics and outcomes in hypertensive patients of Hispanic descent. Prev Cardiol (2008) 11:116-20. doi:10.1111/j.1751-7141.2008.08008.x

406. Yi SS, Tabaei BP, Angell SY, Rapin A, Buck MD, Pagano WG, et al. Self-blood pressure monitoring in an urban, ethnically diverse population: a randomized clinical trial utilizing the electronic health record. Circ Cardiovasc Qual Outcomes (2015) 8:138-45. doi:10.1161/ CIRCOUTCOMES.114.000950

407. Pearson TA, Denke MA, McBride PE, Battisti WP, Brady WE, Palmisano J. A community-based, randomized trial of ezetimibe added to statin therapy to attain NCEP ATP III goals for LDL cholesterol in hypercholesterolemic patients: the ezetimibe add-on to statin for effectiveness (EASE) trial. Mayo Clin Proc (2005) 80:587-95. doi:10.4065/80.5.587

408. Albert MA, Glynn RJ, Fonseca FAH, Lorenzatti AJ, Ferdinand KC, MacFayden JG, et al. Race, ethnicity, and the efficacy of rosuvastatin in primary prevention: the justification for the use of statins in prevention: an intervention trial evaluating rosuvastatin (JUPITER) trial. Am Heart J (2011) 162:106-14. doi:10.1016/j.ahj.2011.03.032

409. Lloret R, Ycas J, Stein M, Haffner SM; STARSHIP Study Group. Comparison of rosuvastatin versus atorvastatin in Hispanic-Americans with hypercholesterolemia (from the STARSHIP trial). Am J Cardiol (2006) 98:769-73. doi:10.1016/j.amjcard.2006.04.014

410. Rosenstock J, Hernandez-Triana E, Handelsman Y, Misir S, Jones MR Clinical effects of colesevelam in Hispanic subjects with primary hyperlipidemia and prediabetes. Postgrad Med (2012) 124:14-20. doi:10.3810/ pgm.2012.07.2564

411. Guzmán JR, Lyra R, Aguilar-Salinas CA, Cavalcanti S, Escaño F, Tambasia M, et al. Treatment of type 2 diabetes in Latin America: a consensus statement by the medical associations of 17 Latin American countries. Rev Panam Salud Publica (2010) 28:463-71. doi:10.1590/S1020-49892010001200008

412. Pan American Health Organization. Diabetes in the Americas [Internet]. Twenty-third Street, N.W (DC) (2016). Available from: http://www2.paho. org/hq/index.php?option $=$ com_content $\&$ view $=$ article $\&$ id $=12126 \% 3 \mathrm{~A}$ diabetes-in-the-americas $\&$ catid $=6648 \% 3$ Afact-sheets $\&$ Itemid $=40721 \&$ lang=en

413. Popkin BM, Hawkes C. Sweetening of the global diet, particularly beverages: patterns, trends, and policy responses. Lancet Diabetes Endocrinol (2016) 4:174-86. doi:10.1016/S2213-8587(15)00419-2

414. Colón-Ramos U, Monge-Rojas R, Campos H. Impact of WHO recommendations to eliminate industrial trans-fatty acids from the food supply in Latin America and the Caribbean. Health Policy Plan (2014) 29:529-41. doi:10.1093/heapol/czt034

415. Argentina, Ministerio de Salud de la Nación [Ministry of Health of the Nation, Argentina]. Iniciativa Menos Sal, Más Vida [Less Salt, More Life Initiative] [Homepage on the Internet]. Buenos Aires, Argentina: Ministerio de Salud, Presidencia de la Nación (2017). Available from: http://www.msal. gob.ar/ent/index.php/informacion-para-ciudadanos/menos-sal--vida

416. Buitrago Gonzáez AR, Escobar NP, Hernández Torres BC, Moreno Barrera CP. Estrategia nacional para la reducción del consumo de sal/sodio en Colombia 2012-2021 [National Strategy for the Reduction of Salt/Sodium Consumption in Colombia 2012-2021]. Bogotá, Colombia: Ministry of Health and Social Protection (2015). 37 p. Spanish. Available from: https:// www.minsalud.gov.co/sites/rid/Lists/BibliotecaDigital/RIDE/VS/PP/SNA/ Estrategia-reduccion-sal-2012-2021.pdf 
417. Nilson EA. The strides to reduce salt intake in Brazil: have we done enough? Cardiovasc Diagn Ther (2015) 5:243-7. doi:10.3978/j.issn.22233652.2015.04.03

418. Pan American Health Organization. Policy Statement: Preventing Cardiovascular Disease in the Americas by Reducing Dietary Salt Intake PopulationWide [Internet]. Twenty Third Street, N.W (DC) (2017). Available from: http://www1.paho.org/hq/dmdocuments/2010/red-salt-policy-statementeng.pdf

419. Valenzuela K, Quitral V, Villanueva AB, Zavala F, Atalah E. Evaluación del programa piloto de reducción de sal/sodio en el pan en Santiago de Chile. Rev Chil Nutr (2013) 40:119-22. doi:10.4067/S0717-75182013000200004

420. Gómez LF, Mosquera J, Gómez OL, Moreno J, Pinzón JD, Jacoby E, et al. Social conditions and urban environment associated with participation in the Ciclovía program among adults from Cali, Colombia. Cad Saude Publica (2015) 31(Suppl 1):257-66. doi:10.1590/0102-311X00086814

421. Gill C, Vatcheva KP, Pan JJ, Smulevitz B, McPherson DD, Fallon M, et al. Frequency of nonalcoholic fatty liver disease and subclinical atherosclerosis among young Mexican Americans. Am JCardiol (2017) 119:1717-22. doi:10.1016/j.amjcard.2017.03.010

422. Kallwitz ER, Daviglus ML, Allison MA, Emory KT, Zhao L, Kuniholm MH, et al. Prevalence of suspected nonalcoholic fatty liver disease in Hispanic/ Latino individuals differs by heritage. Clin Gastroenterol Hepatol (2015) 13:569-76. doi:10.1016/j.cgh.2014.08.037

423. Szczepaniak LS, Victor RG, Mathur R, Nelson MD, Szczepaniak EW, Tyer N, et al. Pancreatic steatosis and its relationship to $\beta$-cell dysfunction in humans: racial and ethnic variations. Diabetes Care (2012) 35:2377-83. doi:10.2337/ dc12-0701

424. McAuley PA, Hsu FC, Loman KK, Carr JJ, Budoff MJ, Szlo M, et al. Liver attenuation, pericardial adipose tissue, obesity, and insulin resistance: the multi-ethnic study of atherosclerosis (MESA). Obesity (2011) 19:1855-60. doi:10.1038/oby.2011.191

425. Troncoso Sawyer M, Deines CK. Missing the mark with Latina women with type 2 diabetes: implications for educators. Diabetes Educ (2013) 39:671-8. doi:10.1177/0145721713495716

426. Pyatak EA, Florindez D, Peters AL, Weigensberg MJ. "We are all gonna get diabetic these days": the impact of a living legacy of type 2 diabetes on Hispanic young adults' diabetes care. Diabetes Educ (2014) 40:648-58. doi:10.1177/0145721714535994

427. Scollan-Koliopoulos M, Walker EA, Rapp KJ. Self-regulation theory and the multigenerational legacy of diabetes. Diabetes Educ (2011) 37:669-79. doi:10.1177/0145721711416133

428. Buckley J, Yekta S, Joseph V, Johnson H, Oliverio S, De Groot AS. Vida Sana: a lifestyle intervention for uninsured, predominantly Spanish-speaking immigrants improves metabolic syndrome indicators. J Community Health (2015) 40:116-23. doi:10.1007/s10900-014-9905-z

429. Gutierrez J, Devia C, Weiss L, Chantarat T, Ruddock C, Linnell J, et al. Health, community, and spirituality: evaluation of a multicultural faithbased diabetes prevention program. Diabetes Educ (2014) 40:214-22. doi:10.1177/0145721714521872

430. Parikh P, Simon EP, Fei K, Looker H, Goytia C, Horowitz CR. Results of a pilot diabetes prevention intervention in East Harlem, New York city: project HEED. Am J Public Health (2010) 100(Suppl 1):S232-9. doi:10.2105/ AJPH.2009.170910

431. Billimek J, Sorkin DH. Food insecurity, processes of care, and self-reported medication underuse in patients with type 2 diabetes: results from the California Health Interview Survey. Health Serv Res (2012) 47:2159-68. doi:10.1111/j.1475-6773.2012.01463.x

432. Haffner SM, Stern MP, Hazuda HP, Mitchell BD, Patterson JK. Cardiovascular risk factors in confirmed prediabetic individuals: does the clock for coronary heart disease start ticking before the onset of clinical diabetes? JAMA (1990) 263:2893-8. doi:10.1001/jama.263.21.2893

433. Pérez CM, Soto-Salgado M, Suárez E, Guzmán M, Ortiz AP. High prevalence of diabetes and prediabetes and their coexistence with cardiovascular risk factors in a Hispanic community. J Immigr Minor Health (2015) 17:1002-9. doi:10.1007/s10903-014-0025-8

434. Handelsman Y, Bloomgarden ZT, Grunberger G, Umpierrez G, Zimmerman RS, Bailey TS, et al. American Association of Clinical Endocrinologists and American College of Endocrinology - clinical practice guidelines for developing a diabetes mellitus comprehensive care plan - 2015 . Endocr Pract (2015) 21(Suppl 1):1-87. doi:10.4158/EP15672.GL

435. Hamman RF, Horton E, Barrett-Connor E, Bray GA, Christophi CA, Crandall J, et al. Factors affecting the decline in incidence of diabetes in the diabetes prevention program outcomes study (DPPOS). Diabetes (2015) 64:989-98. doi:10.2337/db14-0333

436. Hiver MF, Jablonski KA, Perreault L, Saxena R, McAteer JB, Franks PW, et al. Updated genetic scores based on 34 confirmed type 2 diabetes loci is associated with diabetes incidence and regression to normoglycemia in the diabetes prevention program. Diabetes (2011) 60:1340-8. doi:10.2337/ db10-1119

437. Resnicow K, Baranowski T, Ahluwalia JS, Braithwaite RL. Cultural sensitivity in public health: defined and demystified. Ethn Dis (1999) 9:10-21.

438. Glazier RH, Bajcar J, Kennie NR, Willson K. A systematic review of interventions to improve diabetes care in socially disadvantaged populations. Diabetes Care (2006) 29:1675-88. doi:10.2337/dc05-1942

439. Anker AE, Feeley TH, McCracken B, Lagoe CA. Measuring the effectiveness of mass-mediated health campaigns through meta-analysis. $J$ Health Commun (2016) 21:439-56. doi:10.1080/10810730.2015.1095820

440. Lindberg NM, Stevens VJ. Immigration and weight gain: Mexican-American women's perspectives. J Immigr Minor Health (2011) 13:155-60. doi:10.1007/ s10903-009-9298-8

441. Lindberg NM, Stevens VJ, Halperin RO. Weight loss interventions for Hispanic populations: the role of culture. J Obes (2013) 2013:1-6. doi:10.1155/ 2013/542736

442. Chomsky-Higgins K, Miclau TA, Mackechnie MC, Aguilar D, Rubio Avila J, Baldy dos Reis F, et al. Barriers to clinical research in Latin America. Front Public Health (2017) 5:57. doi:10.3389/fpubh.2017.00057

443. Cardenas MK, Miranda JJ, Beran D. Delivery of type 2 diabetes care in low- and middle-income countries: lessons from Lima, Peru. Diabet Med (2016) 33:752-60. doi:10.1111/dme.13099

444. Owolabi M, Miranda JJ, Yaria J, Ovbiagele B. Controlling cardiovascular diseases in low and middle-income countries by placing proof in pragmatism. BMJ Glob Health (2016) 1:e000105. doi:10.1136/bmjgh-2016-000105

Disclaimer: The views expressed in this manuscript are those of the authors and do not necessarily represent the views of the National Heart, Lung, and Blood Institute; the National Institutes of Health; or the US Department of Health and Human Services.

Conflict of Interest Statement: The authors declare that the research was conducted in the absence of any commercial or financial relationships that could be construed as a potential conflict of interest.

Copyright (c) 2017 Avilés-Santa, Colón-Ramos, Lindberg, Mattei, Pasquel and Pérez. This is an open-access article distributed under the terms of the Creative Commons Attribution License (CC BY). The use, distribution or reproduction in other forums is permitted, provided the original author(s) or licensor are credited and that the original publication in this journal is cited, in accordance with accepted academic practice. No use, distribution or reproduction is permitted which does not comply with these terms. 


\section{APPENDIX}

\section{Abbreviations}

AA(s)

ACE inhibitor

$A D$

ARB

ADA

AHEI

BCAAs

BMI

BRFSS

BW

CARMELA

CESCAS I

CRONICAS

CRP

CV

CVD

DASH

DEBI

DM

DNA

DPP

ELSA-Brasil

FFA

FBG

FPG

FSIGT

FTO

GDM

GEM

GRS

GUARDIAN

GWAS
African American(s)

angiotensin-converting enzyme inhibitor

Alzheimer's disease

angiotensin II receptor blocker

American Diabetes Association

alternate health eating index

branched-chain amino acids

body mass index

Behavioral Risk Factor Surveillance Survey

birth weight

cardiovascular risk factor multiple evaluation in Latin America

Centro de Excelencia en Salud Cardiovascular para el Cono

Sur 1

Centro de Excelencia de Enfermedades Crónicas

$\mathrm{C}$ reactive protein

cardiovascular

cardiovascular disease

dietary approaches to stop hypertension

diet exercise and breastfeeding intervention

diabetes mellitus

deoxyribonucleic acid

Diabetes Prevention Program

Estudo Longitudinal de Saúde do Adulto

free fatty acids

fasting blood glucose

fasting plasma glucose

frequently sampled intravenous glucose tolerance test

alpha-ketoglutarate dependent dioxygenase

gestational diabetes mellitus

gestational diabetes' effects on moms

genetic risk score

genetics underlying diabetes in Hispanics

genome wide association studies

\begin{tabular}{|c|c|}
\hline $\mathrm{HbA} 1 \mathrm{c}$ & hemoglobin A1c \\
\hline $\mathrm{HCHS} / \mathrm{SOL}$ & Hispanic Community Health Study/Study of Latinos \\
\hline HDL-C & high-density lipoprotein cholesterol \\
\hline Hispanic HANES & Hispanic Health and Nutrition Examination Survey \\
\hline OMA-IR & homeostasis model assessment for insulin resistance \\
\hline IDF & International Diabetes Federation \\
\hline IGT & impaired glucose tolerance \\
\hline IL-6 & interleukin 6 \\
\hline PD & ketosis prone diabetes \\
\hline LASO & Latin American Consortium of Studies in Obesity \\
\hline LDL-C & low-density lipoprotein cholesterol \\
\hline 1CP-1 & macrophage chemoattractant protein 1 \\
\hline UESA & Multi-Ethnic Study of Atherosclerosis \\
\hline JCEP & National Cholesterol Education Program \\
\hline NHANES & National Health and Nutrition Examination Survey \\
\hline NHIS & National Health Interview Survey \\
\hline $\mathrm{JHB}(\mathrm{s})$ & non-Hispanic black(s) \\
\hline $\mathrm{NHW}(\mathrm{s})$ & non-Hispanic white(s) \\
\hline OGTT & oral glucose tolerance test \\
\hline $\mathrm{OMB}$ & office of management and budget \\
\hline OSA & obstructive sleep apnea \\
\hline PA & physical activity \\
\hline $\mathrm{PAHO}$ & Pan American Health Organization \\
\hline PPAR & peroxisome proliferator-activated receptor \\
\hline $\mathrm{RCT}(\mathrm{s})$ & randomized clinical trial(s) \\
\hline $\mathrm{REACH}$ & racial and ethnic approaches to community health \\
\hline SAHS & San Antonio Heart Study \\
\hline SNPS & single-nucleotide polymorphisms \\
\hline Type 1 DM & Type 1 diabetes mellitus \\
\hline Type 2 DM & Type 2 diabetes mellitus \\
\hline TGs & triglycerides \\
\hline TCF7L2 & transcription factor 7 -like 2 \\
\hline TNF- $\alpha$ & tumor necrosis factor alpha \\
\hline US & United States \\
\hline $\mathrm{WHO}$ & World Health Organization \\
\hline
\end{tabular}

